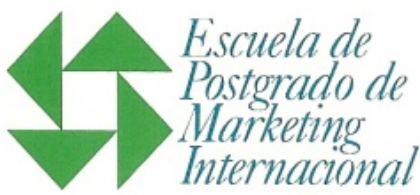

\title{
Título: Creación de marca de lencería femenina para latino-américa a partir del conocimiento de la mujer actual
}

Trabajo Científico libre para la obtención del grado de Magister en Marketing Internacional de la Escuela de Postgrado de Marketing Internacional -Facultad de Ciencias Económicas - Universidad Nacional de La Plata -

Profesor Director de Tesis:

Prof. Dr. Jorge Almada
Presentado por: Julián Andrés Mendoza O'Byrne

Calle 39 NN$^{\circ} 1320$ (1900) La Plata

Fecha de Entrega: 22-03-2019 


\section{PROLOGO Y AGRADECIMIENTOS}

El presente trabajo de tesis, de investigación es el cierre de un ciclo académico de posgrado: maestría en Marketing Internacional, pero a su vez es una luz en el camino para muchas, y en especial para mí como estudiante, que ha adoptado el presente trabajo como un puntapié inicial de un proyecto de vida, que es reflejo latente de una necesidad descubierta en su propio ser, que se reflecta en otros muchos espejos que caminan a diario por las grandes ciudades, buscando incesantemente ser el reflejo de su propio ser y no el que otros han impuesto a nuestras personas, a través de modelos de belleza, sobrenombres, modelos de vida o cualquier otra alineación impuesta que nos hace perder el rumbo de nuestra propia singularidad.

Lo interesante es que no es casualidad sino causalidad, que se decidió para el estudio de tesis el siguiente tema: la creación de una marca de lencería Femenina para Latino-América a partir del conocimiento de la mujer actual, que mejor ejemplo, que ellas, que día a día viven cuestionando el significado de la palabra belleza, persiguiendo un modelo impuesto por un mercado, que no coincide la mayoría de veces con lo que ven reflejado de su propio ser. Ellas han olvidado que el mercado, las sociedades o las marcas no las determinan, son ellas las que le dan vida a las marcas.

"Los verdaderos gigantes siempre han sido poetas, hombres que saltan de los hechos a las ideas y a la imaginación" (Bill Bernbach) 


\section{TABLA DE CONTENIDO}

PROLOGO Y AGRADECIMIENTOS

Introducción Metodológica ..........................................................................................5

Objetivo general .................................................................................................................................................... 5

Objetivos específicos.................................................................................................................................. 5

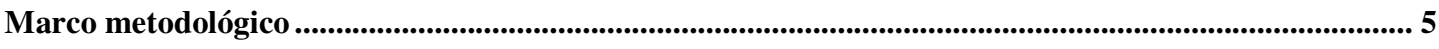

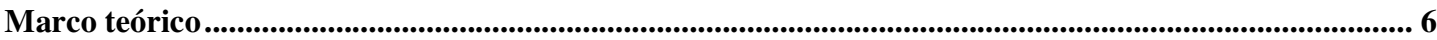

1. CONCEPTUALIZACIÓN DEL PERFIL DE MUJER LATINA DE INTERÉS PARA LO

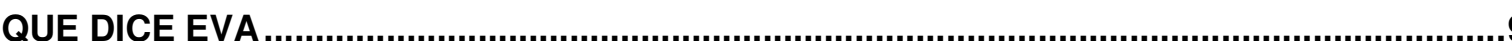

1.1 Fisionomía física y la conformación corporal de la mujer latina ..................................................... 9

1.1.1 Síntesis clasificatoria por países según tipo de mujer:....................................................... 11

1.2 Pensamiento de la mujer actual en relación a la estética y el mundo de la belleza...................... 12

1.2.1 Construcción conceptual e idealización de la belleza ........................................................ 12

1.2.2 Mundo consumo, belleza femenina y la mujer latina ....................................................... 14

1.2.3 Conceptualización de los motivos de elección y usos de la lencería ....................................... 15

1.3 Análisis del mercado de lencería latinoamericano ...................................................................... 17

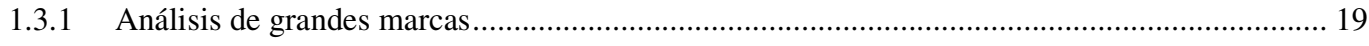

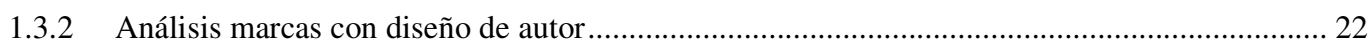

2. RELEVAMIENTO DEL PENSAMIENTO DE LA DEMANDA...........................................24

2.1 Encuestas de opinión a la mujer actual sobre la lencería, usos y necesidades ............................ 24

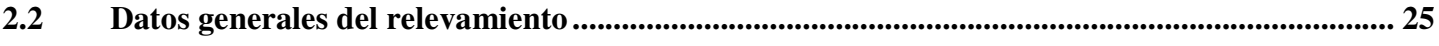

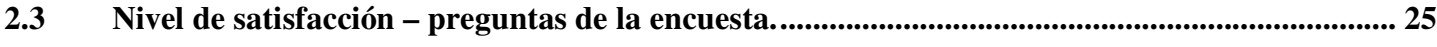

2.3.1 Relación tipo de mujer con las marcas ............................................................................... 27

2.4 Atributos de la marca según la consumidora latinoamericana ..............................................29

2.4.1 Top of mind de marcas de lencería para la mujer latina ....................................................... 29

2.4.2 Mención de marcas por grupo de mujeres de interés:....................................................... 30

2.4.3 Atributos de marca de lencería femenina para la mujer latina............................................... 30

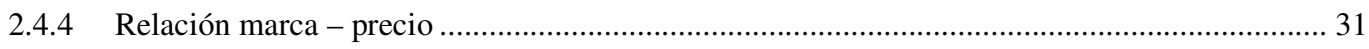

2.5 Motivos de elección que movilizan a la mujer latina................................................................... 32

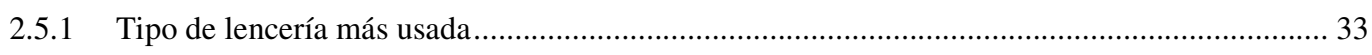

2.5.2 Frecuencia de compra de la mujer latina ......................................................................... 34

2.5.3 Sondeo de información de producto. ¿Cuáles son los medios/lugares que usted consulta regularmente para enterarse del mundo de la lencería y sus marcas? .............................................. 34

2.5.4 Lugar de compra: ¿usualmente cuando compra donde lo hace?......................................... 35

2.5.5 Atributos del producto: prioridad al momento de compra que tienen para usted al elegir ........ 36

3. DEFINICIÓN DE LA CONCEPTUALIZACIÓN DE LA MARCA LO QUE DICE EVA .........37

3.1 Definición del prototipo y perfil de mujer de interés para la marca.............................................. 37 
3.2 Mercado meta de interés para la marca ........................................................................................ 38

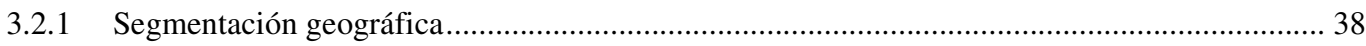

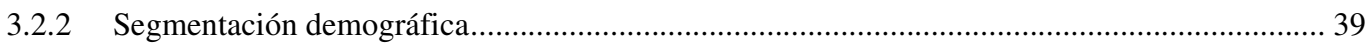

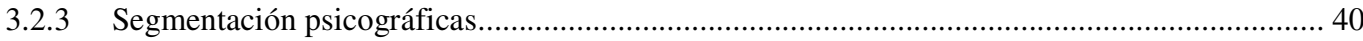

3.3 Diseño y desarrollo del perfil de la marca..................................................................................... 40

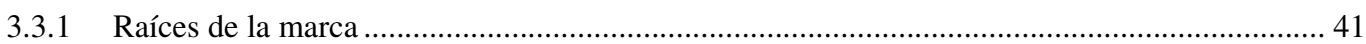

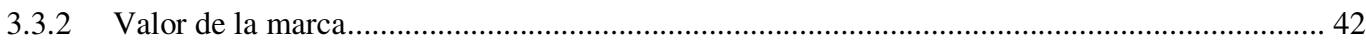

3.3.3 Atributos y beneficios de los productos de la marca ..................................................... 43

3.3.4 Conceptualización y definición del atributo central de la marca .......................................... 44

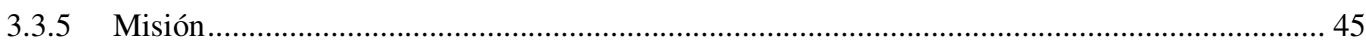

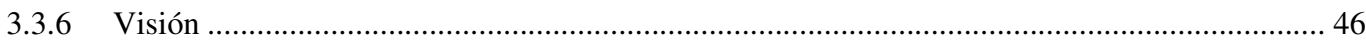

3.4 Diagramación y diseño del producto final (línea/s de colección) …...............................................46

3.5 Creación de distintivos de la marca (logo - etiqueta -empaque) ................................................. 47

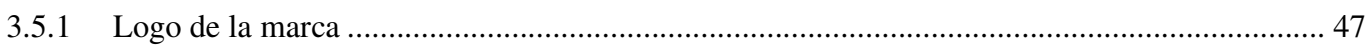

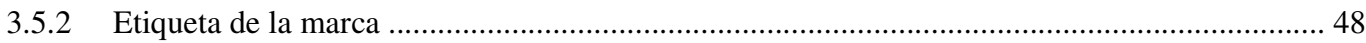

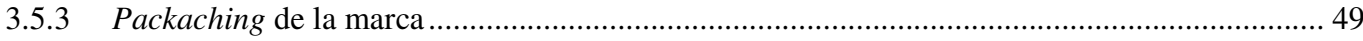

4. DESARROLLO DE LA ESTRATEGIA COMERCIAL, DE POSICIONAMIENTO DE LA MARCA LO QUE DICE EVA

4.1 Estrategia de posicionamiento de la marca ..................................................................................51

4.1.1 Identificación de ventajas competitivas ...................................................................... 51

4.1.2 Selección de ventajas competitivas correctas ................................................................. 52

4.1.3 Selección de la estrategia general de posicionamiento ................................................... 53

4.2 Política de precios de la marca ......................................................................................................5 54

4.3 Estrategia y política comunicacional de la marca y sus productos ..........................................56

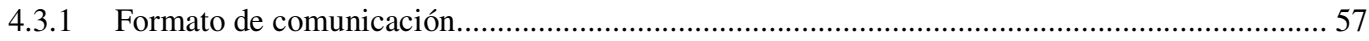

4.3.2 Mezcla de comunicación de marketing .................................................................... 58

4.4 Diagramación de la estrategia de canales y comercialización ....................................................... 61

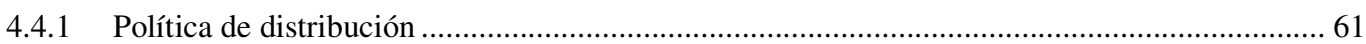

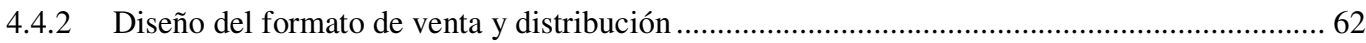

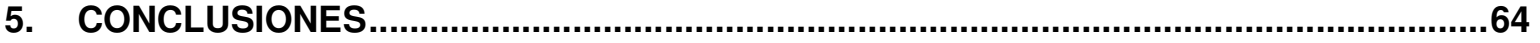

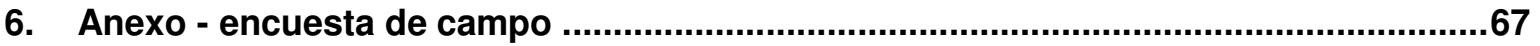

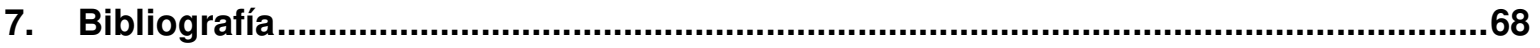

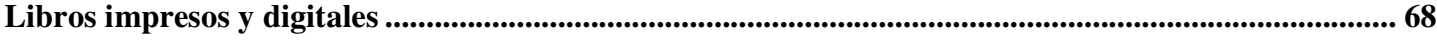

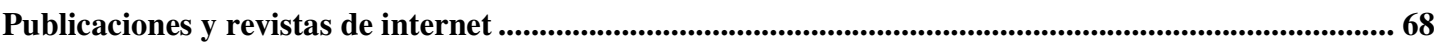

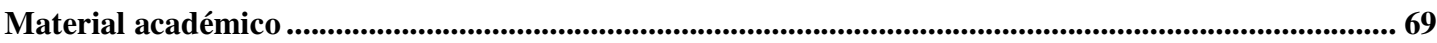




\section{Introducción Metodológica}

\section{Objetivo general}

Constituir un nuevo concepto de marca que identifique a la mujer latina, a partir de la personificación de la sinergia de las necesidades corporales y psicológicas del público Femenino actual.

\section{Objetivos específicos}

1) Conceptualización del perfil de Mujer Latina de interés para Lo que dice Eva

2) Definición de la conceptualización de la Marca Lo que dice Eva

3) Desarrollo de la estrategia comercial, de posicionamiento de la Marca Lo que dice Eva

\section{Marco metodológico}

El presente trabajo de investigación y de tesis pretende la creación y posicionamiento de la marca de lencería femenina Lo que dice Eva, para ello propone la implementación de una metodología descriptiva como marco referencial de desarrollo investigativo, la cual permitirá confrontar las diferentes temáticas argumentales a plantearse a lo largo del presente trabajo, con el fin de brindar un mayor sustento académico, que soporte la veracidad de las hipótesis. Como paso inicial se apoyará en la exploración de fuentes secundarias, como: libros, documentos de cámaras, noticias y otros documentos científicos relacionados que puedan darle profundidad y forma a dichas hipótesis iniciales.

En segunda instancia y en concordancia con el lineamiento metodológico inicial se pretende recabar información cualitativa y cuantitativa a través de la realización de encuestas ejecutivas a líderes de opinión, expertos del rubro, tanto a nivel de la moda y comercial, para profundizar las ideas pre-establecidas sobre la dinámica-funcionamiento del mercado actual, y las necesidades del público femenino en cuanto a la elección de lencería, desde la visión de la oferta. Como paso definitivo se contrastará toda la información con encuestas coincidentales de cuestionario semi-estructurado a realizarse al mercado objetivo, como medida ratificatoria y definitiva de la concepción previa del autor. 


\section{Marco teórico}

En primera instancia traemos a colación un aparte de un libro sencillo pero interesante de una diseñadora de indumentaria argentina, que se formó principalmente en Europa, en la Domus Academy de Milán y en Copenhague, en el que se plantea por qué y para qué nos vestimos, es una "pregunta que ha desvelado a antropólogos, etnólogos, semiólogos y religiosos, y también a simples mortales", cuya respuesta develada está enmarcada en una sencilla y escueta definición: "'Hay pueblos que no se visten, pero no hay pueblos que no se adornen. Nos vestimos para adornarnos y embellecernos. La ropa nos permite también diferenciarnos, mostrar rangos, ocupaciones, pertenencias, identidades". A partir de dicho preámbulo es que el presente trabajo de tesis pretende crear una marca de lencería femenina para latino-américa a partir del conocimiento de la mujer actual.

Es por ello que toma como punto de partida la raza que da origen a la mujer latina que 2"no tiene historia conocida antes de América. Quizás se originó como referencia a las diferencias fenotípicas entre conquistadores y conquistados, pero lo que importa es que muy pronto fue construida como referencia a supuestas estructuras biológicas diferenciales entre esos grupos".

Para este tipo de mujeres se pretende generar una marca con un concepto que no genere ni alimente pensamientos inadecuados en ellas por su mezcla de etnias como:

3"no están delgadas, que no son suficientemente guapas, y se comparan con las imágenes imposibles de los ídolos aerografiados en las revistas”

\footnotetext{
${ }_{1}^{1}$ Aubele, C. (2015). Secretos del Vestidor. Buenos Aires: Aguilar.

${ }^{2}$ Quijano, A. (2000). Colonialidad del Poder, Eurocentrismo y América Latina. En La Colonialidad del Saber: Eurocentrismo y Ciencias Sociales. Perspectivas Latinoamericanas. Recuperado de http://bibliotecavirtual.clacso.org.ar/ar/libros/lander/quilano.rtf

${ }^{3}$ Zygmunt, B. (2011), La Llegada de las Niñas-Mujeres. En Espasa Libros (Eds.), 44 Cartas desde el Mundo Líquido (pp.65-68). Barcelona: Editorial Espasa libros S.L.U.
} 
En concordancia a lo anteriormente mencionado, lo que también se pretende es evitar la sinergia e identificación de la marca a construir con el pensamiento nocivo del mercado actual de la moda, "“como afirma Hadley Freeman en un resumen sucinto pero incisivo publicado en el Guardián el 9 de septiembre del 2009, a la industria de la moda no le interesa que las mujeres se sientan mejor consigo mismas. La moda consiste en lograr que la gente desee algo improbable de cumplimiento [...] y toda satisfacción lograda resulta fugaz y ligeramente decepcionante".

Posteriormente se procederá a construir un perfil de la marca, que permita que ellas se identifiquen fácilmente. Para ello es importante contar con conceptos teóricos de marketing que sustenten la concreta y correcta creación de la misma, con el fin de lograr el éxito del proyecto. Dicho perfil se estructurará sobre el valor de la marca, "'que tiene un valor positivo cuando los consumidores reaccionan de manera favorable ante ella que ante una versión genérica o privada del mismo producto", para ello es fundamental generar posteriormente el posicionamiento del perfil en la mente de los clientes meta, a través de los atributos, beneficios, creencias y valores de la marca como lo define Philip Kotler/Gary Armstrong $(2012)^{6}$

En dicho camino para el posicionamiento en la mente de la consumidora y sustentabilidad en el tiempo de la marca, el presente proyecto además de diseñar una estrategia de posicionamiento también se apoyará en tópicos claves del marketing, que están relacionados con la construcción de la estrategia de comercialización, política de comunicación adecuada para que le permitan llegar al consumidor meta.

En definitiva, se apoyará en el pensamiento sistémico de Philip Kotler y

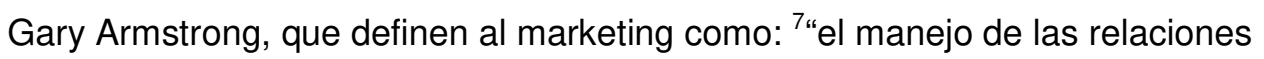
redituables con el cliente. El objetivo consiste en crear valor para los clientes y obtener valor a cambio de ellas, definido en términos generales como un proceso social y administrativo mediante el cual los individuos y las organizaciones obtienen lo que necesitan y desean, creando e intercambiando valor con otros,

\footnotetext{
${ }^{4}$ Zygmunt, B. (2011), La Moda, o el Movimiento Perpetuo. En Espasa Libros (Eds.), 44 Cartas desde el Mundo Líquido (pp.73-77). Barcelona: Editorial Espasa libros S.L.U.

${ }^{5}$ Kotler, P \& Armstrong, G. (2012). Estrategia de asignación de marcas. En Pearson Education (Eds.), Marketing (pp.243-246). Ciudad de México: Pearson Editorial.

${ }^{6}$ Kotler, P \& Armstrong, G. (2012). Marketing. En Pearson Education (Eds.). Ciudad de México: Pearson Editorial.

${ }^{7}$ Kotler, P \& Armstrong, G. (2012). Marketing Creación y Captación de Valor del Cliente. En Pearson Education (Eds.), Marketing (pp.2-9). Ciudad de México: Pearson Editorial.
} 
definiendo como clave de éxito para cualquier negocio y su sustentabilidad a largo del tiempo la investigación de mercados y el entendimiento de las necesidades del cliente para optar por las condiciones adecuadas en el encauce del negocio". 


\section{CONCEPTUALIZACIÓN DEL PERFIL DE MUJER LATINA DE INTERÉS PARA LO QUE DICE EVA}

\subsection{Fisionomía física y la conformación corporal de la mujer latina}

Cualquier marca nueva, o de gran trayectoria en el mercado antes de lanzar un artículo y/o servicio debe cuestionarse primero si tiene verdaderamente en claro las necesidades, los gustos y los motivadores de compra del nicho a cuál va dirigido su lanzamiento. Por tal motivo es pertinente tener como premisa el realizarse el siguiente cuestionamiento: ¿Realmente conozco al público al cual

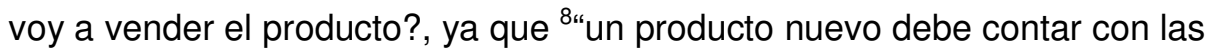
características funcionales requeridas y transmitir además los rasgos psicológicos deseados" por el cliente para que obtenga la mayor probabilidad de éxito dentro del público objetivo.

De lo contrario puede ocasionar el resultado inverso, llevando a generar trastornos en la población, como por ejemplo en las niñas, que serán en un futuro las clientas de la marca Lo que dice Eva, como señala 9"Un estudio longitudinal elaborado por el Reino Unido bajo la dirección de Bob Reitemeier, el presidente de la Children's Society, donde se pone de manifiesto que menos del 20 por ciento de los niños juega fuera de la casa, mientras que la mayoría de las niñas de 10 años <están obsesionadas con el pelo, la moda, y el maquillaje>, y en el 26 por ciento de los casos creen que no están bastante delgadas y se obsesionan con el peso. Reitemeier observa con alarma el rápido incremento de los niveles de ansiedad ente las niñas, que creen que <no están delgadas, que no son

\footnotetext{
${ }^{8}$ Kotler, P \& Armstrong, G. (2012). Diseño de una Estrategia y una Mezcla de Marketing Impulsada por los Consumidores. En Pearson Education (Eds.), Marketing (pp.266-267). Ciudad de México: Pearson Editorial. ${ }^{9}$ Zygmunt, B. (2011), La Llegada de las Niñas-Mujeres. En Espasa Libros (Eds.), 44 Cartas desde el Mundo Líquido (pp.65-68). Barcelona: Editorial Espasa libros S.L.U.
} 
suficientemente guapas, y se comparan con las imágenes imposibles de los ídolos aerografiados en las revistas>"

Es por ello que se tomó la decisión para la creación de la marca mencionada primero hacer un parate y reparar en aquellas generalidades físicas y estéticas de la mujer latinoamericana: como lo son los rasgos corporales específicos que enmarcan y distinguen a la mujer latina dentro del género femenino. Facilitando el abordaje del público objetivo mencionado para la marca, y al mismo tiempo generar satisfacción en ellas al momento que elijan usar las creaciones de ésta.

La raza que construye a la mujer latina ${ }^{10 " n o ~ t i e n e ~ h i s t o r i a ~ c o n o c i d a ~ a n t e s ~ d e ~}$ América. Quizás se originó como referencia a las diferencias fenotípicas entre conquistadores y conquistados, pero lo que importa es que muy pronto fue construida como referencia a supuestas estructuras biológicas diferenciales entre esos grupos.

La idea de raza es, literariamente, un invento. No tiene nada que ver con la estructura biológica de la especia humana. En cuanto a los rasgos fenotípicos, éstos se hallan obviamente en el código genético de los individuos y grupos, y en ese sentido específico son biológicos." Por ello se ha decidido distinguir a la mujer latina en grupos de países que tuvieron un mestizaje similar, a raíz de la migración que vivió su población, creando de esta manera un código genético entre ellos, que permite identificar los diferentes tipos de mujer latina que actualmente pueden existir. Los llamaremos tipos de mujer para establecer un término, y así poder delimitar aspectos físicos equivalentes entre ellas; desde las similitudes de rasgos y características afines que se formaron en los distintos códigos genéticos de las latinas por la mezcla de "razas".

En los países del llamado Cono Sur de América Latina la mayoría es blanca, (Argentina, Chile y Uruguay) ya que sufrieron una colonización parecida a la de Estados Unidos. ${ }^{11 " ~ L o s ~ i n d i o s ~ e n ~ s u ~ m a y o r i ́ a, ~ t a m p o c o ~ f u e r o n ~ i n t e g r a d o s ~ a ~ l a ~ s o c i e d a d ~}$ colonial". ${ }^{12 " E n ~ e s t o s ~ t r e s ~ p a i ́ s e s, ~ t a m b i e ́ n ~ l a ~ p o b l a c i o ́ n ~ n e g r a ~ f u e ~ u n a ~ m i n o r i ́ a ~ d u r a n t e ~ e l ~}$ período colonial, en comparación con otras regiones dominadas por españoles o portugueses. Y los dominantes de los nuevos países del cono sur consideraron, como en el caso de los Estados Unidos, necesaria la conquista del territorio que los indios

\footnotetext{
${ }^{10}$ Quijano, A.(2000). Colonialidad del Poder, Eurocentrismo y América Latina. En La Colonialidad del Saber: Eurocentrismo y Ciencias Sociales. Perspectivas Latinoamericanas. Recuperado de http://bibliotecavirtual.clacso.org.ar/ar/libros/lander/quijano.rtf ${ }_{11}$ Quijano, A.(2000). Colonialidad del Poder, Eurocentrismo y América Latina. En La Colonialidad del Saber: Eurocentrismo y Ciencias Sociales. Perspectivas Latinoamericanas. Recuperado de http://bibliotecavirtual.clacso.org.ar/ar/libros/lander/quijano.rtf

${ }_{12}$ Quijano, A.(2000). Colonialidad del Poder, Eurocentrismo y América Latina. En La Colonialidad del Saber: Eurocentrismo y Ciencias Sociales. Perspectivas Latinoamericanas. Recuperado de http://bibliotecavirtual.clacso.org.ar/ar/libros/lander/quijano.rtf
} 
poblaban y el exterminio de éstos como forma expeditiva de homogenizar la población nacional y de ese modo facilitar el proceso de constitución de un Estado-nación moderno, a la europea. En Argentina y Uruguay eso fue hecho en el siglo XIX. y en Chile durante las primeras décadas del siglo XX”. Llegando a tener una mujer similar en características fenotípicas a la mujer blanca europea y norteamericana.

En cambio, en países como Colombia, Venezuela, Brasil, México, Bolivia y donde los indígenas y negros fueron conservados para trabajar de forma gratuita, hicieron que la estructura poblacional se conformara en un ${ }^{13}$ " $90 \%$ del total de su población por negros, indios y mestizos". Mestizos que nacieron por la mezcla de razas que eran dominadas por"la pequeña minoría blanca que asumió el control de esos Estados gracias a las libertades que se vivía en estos territorios al estar libres de la legislación de la corona española, que se dirigía formalmente a la protección de las razas colonizadas" logrando conformar dos tipos de mujer, una más mestiza similar entre Colombia, Venezuela y Brasil, y otra más con rasgos indígenas similar a la mujer de Perú y Bolivia.

\subsubsection{Síntesis clasificatoria por países según tipo de mujer:}

\begin{tabular}{|c|l|c|}
\hline Agrupación por Países & \multicolumn{1}{|c|}{ Rasgos Clasificatorios } & $\begin{array}{c}\text { Denominación de la } \\
\text { Mujer }\end{array}$ \\
\hline $\begin{array}{c}\text { Argentina-Chile- } \\
\text { Paraguay-Uruguay }\end{array}$ & $\begin{array}{l}\text { Piel: Blanca - Ojos claros } \\
\text { Estatura: } 1.60-1.70 \mathrm{mts} \\
\text { Característica general: Delgada estilizada, piernas } \\
\text { largas, de trasero y busto pequeño }\end{array}$ & $\begin{array}{c}\text { Tipo Uno: Blanca } \\
\text { Anglosajona }\end{array}$ \\
\hline $\begin{array}{c}\text { Colombia-Brasil- } \\
\text { Ecuador- México- }\end{array}$ & $\begin{array}{l}\text { Piel: Mestiza - Ojos claros, semi claros } \\
\text { Estatura: } 1.54-1.65 \text { mts } \\
\text { Característica general: Mediana estatura, caderas } \\
\text { marcadas, cuerpo definido piernas torneadas }\end{array}$ & $\begin{array}{c}\text { Tipo Dos: Mestiza- } \\
\text { mezcla de razas }\end{array}$ \\
\hline Colombia-Bolivia-Perú & $\begin{array}{l}\text { Piel: Mestiza - Ojos oscuros } \\
\text { Estatura: 1.53-1.60 mts } \\
\text { Característica general: rasgos indígenas, } \\
\text { corpulenta, senos y trasero mediano. }\end{array}$ & Tipo Tres-Mujer más \\
indígena
\end{tabular}

${ }^{14}$ Fuente: Tabla elaboración propia a partir de datos recolectados de la OMS-Datos mundial

\footnotetext{
${ }_{13}^{13}$ Quijano, A. (2000). Colonialidad del Poder, Eurocentrismo y América Latina. En La Colonialidad del Saber: Eurocentrismo y Ciencias Sociales. Perspectivas Latinoamericanas. Recuperado de http://bibliotecavirtual.clacso.org.ar/ar/libros/lander/quijano.rtf

${ }^{14}$ OMS Datos Mundial. (2017). Tallas medias de hombres y mujeres. Recuperado el 02 de mayo del 2019 de https://www.datosmundial.com/estatura-promedio.php
} 


\subsection{Pensamiento de la mujer actual en relación a la estética y el mundo de la belleza}

\subsubsection{Construcción conceptual e idealización de la belleza}

Para el caso de estudio es pertinente hacer foco, y centrarse en lo que representa representa el concepto de belleza femenina para la mayoría de las personas de las distintas sociedades. ¿Cuál/Cómo es la belleza femenina?, podemos afirmar que el significado de dichos cuestionamientos para la mayoría de las personas en pleno siglo $\mathrm{XXI}$, sin importar la edad o el sexo, es una composición única que fue adoptada por las distintas sociedades actuales como única y representativa que no se cuestiona, y se sigue validando como "verdad"; ${ }^{15}$ “Es preciso detenerse en esa visión de una belleza única, modelo impuesto al espectador sin que él tenga participación. La escena es casi inicial en la modernidad. En tanto belleza que proviene de otra parte, sería una materia incandescente, una fuerza viva, una fuente de fuego", que nació y se construyó de subjetividades de una sociedad del siglo XVI, que validaron su significado a partir de creencias abstractas que atravesaban a esas comunidades en dicho momento socio cultural.

16“"Existen intentos para definir ese absoluto, los que recurren, entre otros expedientes, a interminables juegos literarios centrados en los indicios físicos de lo bello. En realidad, se trata de juegos formales, donde la verdad es ante todo retórica; en ellos no se encuentra ninguna prueba concreta. Son arcaicos juegos medievales sobre los "puntos de la belleza"” que se persiguen en estos textos del siglo XVI para sistematizarlos. A los nueve puntos de Jacob Alighieri, "por ejemplo, discutidos en el siglo XVI ("juventud, piel blanca, cabellos rubios, brazos y piernas bien delineadas...")".

17،“'La lista de cánones se ha multiplicado” reconoce Marie-Claire Phan en su descripción de la belleza en el Renacimiento. "Alargados", por ejemplo, serán el talle, el pelo y la mano. "Breves", las orejas, los pies, los dientes. "Rojos", las uñas, los labios y las mejillas. "Estrechas", la pelvis, la boca y la cintura. "Pequeñas", la cabeza, la nariz...Dicho de otra manera; diez cualidades, cada una de ellas observadas en tres lugares anatómicos diferentes, para que la dama obedezca al "molde de la perfección"

\footnotetext{
${ }^{15}$ Vigarello,G. (2009). Una sola Belleza, La inexplicable irradiación. En Du Seuil (Eds.), Historia de la Belleza (pp. 40-44). Buenos Aires: Editorial Ediciones Nueva Visión.

"Vigarello,G. (2009). Una sola Belleza, Las "sedes" de belleza. En Du Seuil (Eds.), Historia de la Belleza (pp. 40-44). Buenos Aires: Editorial Ediciones Nueva Visión.

${ }^{17}$ Vigarello,G. (2009). Una sola Belleza, Las "sedes" de belleza. En Du Seuil (Eds.), Historia de la Belleza (pp. 41-42). Buenos Aires: Editorial Ediciones Nueva Visión.
} 
Como menciona Georges Vigarello en el libro anteriormente citado, que necesidad de intentar "enunciar fórmulas de belleza", que resultan ser definitivas para la mujer, en lugar de ser incluyentes resultan claramente excluyentes más para la mujer latina en su mayoría, sobre todo para la tipo dos y tres, por dicha

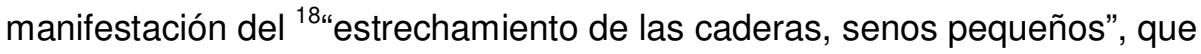
convierten la belleza en una formula única.

Ha sido tal el consenso del inconsciente colectivo sobre el significado de femenina, que las personas siguen validando dicho canon de belleza único que promueven las grandes marcas a través de las aerografías. Donde ${ }^{19}$ "el propósito consiste en alcanzar una cifra que sea como un cómputo: la voluntad de relacionar cada dimensión parcial del cuerpo con su dimensión total, la de establecer las fracciones ideales. La altura de la cabeza, por ejemplo, siempre "debe" ser equivalente a la octava parte de la altura total del cuerpo o la unidad de la cara (entre frente y mentón) siempre "debe" corresponder a tres unidades del tronco, dos de los muslos, dos de las pantorrillas. De ahí también ciertas igualdades notables: el cuerpo humano inmortalizado por Leonardo se inscribe en un círculo, como en un cuadrado, cuyo centro es el ombligo."

Sin embargo, grandes artistas y referentes de dichas sociedades coincidieron y comprueban la dificultad de lograr ${ }^{20 " p r o p o r c i o n e s ~ u n i ́ v o c a s " ~ p a r a ~}$ definir un tipo de belleza femenina para dicha época; menos para la actual y para la mujer de América Latina, que nace de diversas mezclas de rasgos fenotípicos entre las sociedades, que dependen en su mayoría de la migración del territorio al que pertenece. ${ }^{21}$ “Las cifras de Leonardo se vuelven numerosas, contradictorias. Las de Durero se muestran igualmente diversas, presentadas en tipos "característicos", desplegadas desde la "mujer aldeana" hasta la "mujer delgada", formas diferentes entre sí, pero "bellas" a su manera, en tanto bien proporcionadas", coincidiendo que existen diferentes tipos de belleza que puede ser calificada y conceptualizada de diversas formas, dependiendo de la subjetividad que atraviese al interlocutor que la esté observando.

\footnotetext{
${ }^{18}$ Vigarello,G. (2009). Una sola Belleza, Las "sedes" de belleza. En Du Seuil (Eds.), Historia de la Belleza (pp. 41-42). Buenos Aires: Editorial Ediciones Nueva Visión.

${ }^{19}$ Vigarello,G. (2009). Una sola Belleza, El canon y el Ideal. En Du Seuil (Eds.), Historia de la Belleza (pp. 4244). Buenos Aires: Editorial Ediciones Nueva Visión.

${ }^{20}$ Vigarello,G. (2009). Una sola Belleza, El canon y el Ideal. En Du Seuil (Eds.), Historia de la Belleza (pp. 4244). Buenos Aires: Editorial Ediciones Nueva Visión

${ }^{21}$ Vigarello,G. (2009). Una sola Belleza, El canon y el Ideal. En Du Seuil (Eds.), Historia de la Belleza (pp. 4244). Buenos Aires: Editorial Ediciones Nueva Visión
} 


\subsubsection{Mundo consumo, belleza femenina y la mujer latina}

En este tiempo los objetos deseados por la mujer (adolescente y joven mujer), mujer), entre los que encontramos algunas marcas de lencería, ${ }^{22 ، " s o n ~ m a ́ s ~ b a r a t o s, ~ b a j a n ~}$ baratos, bajan de precio y pasan a estar tentadoramente, al alcance de cualquier bolsillo, bolsillo, su adquisición tiende a ser una parte rutinaria de la vida de cualquier persona persona <normal> y corriente, de <cualquiera que sea alguien>, y ya no un acontecimiento extraordinario, excepcional, memorable, por el que haya que dar gracias gracias a Dios o a la buena suerte y escribir a casa para contarlo. El efecto inesperado, y sin embargo ineludible, es que el vínculo emocional con el objeto adquirido brilla casi por su ausencia: lo que verdaderamente cuenta es el momento de la adquisición, o la amistad duradera" con la marca o con el objeto.

Tal vez el significado a este fenómeno anteriormente descrito, que no solo se le atribuye a mujeres de corta edad, sino también atraviesa a hombres. En general no distingue edad o género o nivel socioeconómico, cada individuo tiene sus anhelos personales y por ende podremos encontrar diversidad entre los objetos de deseo proyectados, según el entorno en el que se desenvuelve. En consecuencia una de las tareas a encontrar es ese punto exacto de amistad entre los consumidores y la marca, por tal motivo Lo que dice Eva ha de plantearse en esta instancia es: ¿cuál es ese mercado meta? con el cual puede generar una relación de " fuerza y parentesco", para estar en sincronía con lo que la mujer latina está dispuesta a gastar en lencería, ya que hay muchas mujeres que ${ }^{23 \text { c }}<$ no tienen dinero $>$ para costearse el estilo de vida que la mayoría considera una cuestión de vida o de muerte (social)".

Mujeres que no solo sienten a diario la 24"presión de los anuncios sino también, y probablemente más que ninguna otra cosa, la presión, tal vez menos persistente, pero mucho más efectiva, del entorno social, de los estándares ${ }^{25}$ " de belleza. Estándares que envuelven a la mujer latina a enfocar "su rutina de belleza a lograr que su cuerpo sea, tan esbelto, tonificado, de piel suave, un poco "demasiado" exuberante, quizá, pero bien delineado", que les permita verse armónicas frente al espejo al momento de usar una prenda de lencería, momento tranquilizador a su ego alienado acorde y en armonía, a ese ideal de belleza predefinido, enmarcado anteriormente en el titulo anterior

\section{Construcción Conceptual e Idealización de la Belleza.}

\footnotetext{
${ }^{22}$ Zygmunt, B. (2011), El consumo Adolescente. En Espasa Libros (Eds.), 44 Cartas desde el Mundo Líquido (pp.51-55). Barcelona: Editorial Espasa libros S.L.U.

${ }_{23}$ Zygmunt, B. (2011), El consumo Adolescente. En Espasa Libros (Eds.), 44 Cartas desde el Mundo Líquido (pp.51-55). Barcelona: Editorial Espasa libros S.L.

${ }^{24}$ Zygmunt, B. (2011), El consumo Adolescente. En Espasa Libros (Eds.), 44 Cartas desde el Mundo Líquido (pp.51-55). Barcelona: Editorial Espasa libros S.L.U.

${ }^{25}$ Revista Belleza y Salud. La complexión Latina. Recuperado de: http://www.fucsia.co/belleza-ysalud/articulo/la-complexion-latina/4042
} 


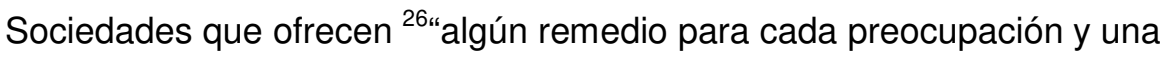
preocupación en cada mujer, así que todas o casi todas las mujeres encontrarán menos un cebo que les haga sentir que el mensaje apunta un dedo acusador amor propio y su orgullo personal, censurándolas por el escaso esmero que cumplimiento de su deber" al no cumplir con ese estándar de belleza que industria de la moda.

Industria, cuyo fin primordial es la generación de rentabilidad para sus accionistas, dejando de lado el interés de acompañar a las mujeres en su camino de la autorrealización, ${ }^{27}$ "como afirma Hadley Freeman en un resumen sucinto pero incisivo publicado en el Guardian el 9 de septiembre del 2009, a la industria de la moda no le interesa que las mujeres se sientan mejor consigo mismas. La moda consiste en lograr que la gente desee algo improbable de cumplimiento [...] y toda satisfacción lograda resulta fugaz y ligeramente decepcionante".

La marca busca actuar en consecuencia y en contraposición a dicha realidad que atraviesa a las diversas sociedades latinas, buscando generar una nueva relación de estrechez con sus consumidoras, vínculo que será construido a partir de aquellos Insight que identifican a la mujer latina, a partir de argumentos que permitan devolverle a la mujer latina esa tranquilidad que les ha sido arrebatada por ser diferentes frente al espejo, y contar con belleza diversa que no es acorde al canon único impuesto y promovido por la industria de la moda.

\subsubsection{Conceptualización de los motivos de elección y usos de la lencería}

Actualmente las mujeres latinas hacen uso de ciertos factores/atributos psicológicos almacenados en el inconciente individual colectivo de las sociedades latinoamericanas para elegir las prendas que lucirán frente al espejo, en pro de satisfacer y encontrar aquel placer irracional alojado en el "ELLO" a través del "YO", afirmación sustentada en los estudios de Sigmund Freud y su teoría del psicoanálisis.

Irracionalidad construida a partir de un concepto de belleza que nació de

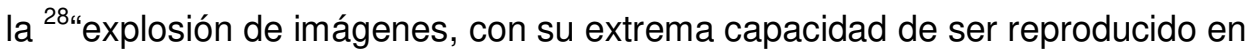

\footnotetext{
${ }^{26}$ Zygmunt, B. (2011), Ahora es el turno de las pestañas. En Espasa Libros (Eds.), 44 Cartas desde el Mundo Líquido (pp.69-72). Barcelona: Editorial Espasa libros S.L.U.

27 Zygmunt, B. (2011), La Moda, o el Movimiento Perpetuo. En Espasa Libros (Eds.), 44 Cartas desde el Mundo Líquido (pp.73-77). Barcelona: Editorial Espasa libros S.L.U.

${ }^{28}$ Vigarello,G. (2009). Una sola Belleza, Acercar las Stars. En Du Seuil (Eds.), Historia de la Belleza (pp. 212229). Buenos Aires: Editorial Ediciones Nueva Visión
} 
todos los continentes, el cine consolida aún más esos criterios-marcas físicas de la vida al aire libre, creciente vigilancia de la silueta, precisión en el maquillaje o en el color del cutis, celebración de los bronceados cuerpos de las sílfides-en el período", generando en el siglo XX ${ }^{29 " u n ~ e s p a c i o ~ P s i c o l o ́ g i c o ~ e n ~ e l ~ q u e ~ l o s ~ i n d i v i d u o s ~ d e ~ l a s ~ s o c i e d a d e s ~}$ democráticas sueñan con innumerables transformaciones, en particular, con someter el conjunto de la apariencia al solo ejercicio de la voluntad".

Explosión comunicacional que marcó un antes y un después en la definición del criterio de belleza, dando cabida a nuevos diseños de lencería y modo de uso de las mismas, modificando automáticamente la forma de consumir de la mujer y el formato de

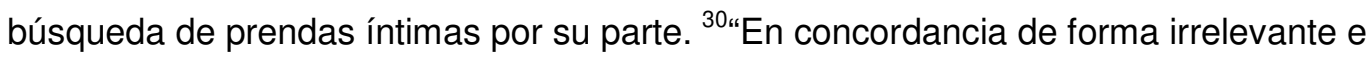
irracionalmente a un estilo de vestir y uso trasgresor de nuevas prendas que surgían y debían asemejarse cada vez más a las que lucían las super stars de la posguerra, las de la década del 50 que a partir de su comportamiento empezaron a imponer el concepto de "libertad" con una nueva tendencia de vestir y comportamiento asociado a un imaginario físico corporal que dieron comienzo a las pautas de hoy, originando el nuevo gusto de la mujer moderna".

Tendencia donde lo primordial ${ }^{31}$ "es la erotización, la presencia de una belleza más provocadora, un aspecto que choca como nunca a las reservas y a los convencionalismos. Las metáforas animales, por ejemplo, triunfan ante la evocación de Bardot, las alusiones felinas sobre todo, añadiendo a los indicadores "exteriores" los de una naturaleza más primitiva por no decir instintiva. Los labios carnosos, el rostro pícaro, la inminencia de los sentidos sugieren a "una hermosura bestezuela de la jungla, enfurruñada, desgreñada.".

32“Las jóvenes de fines de la década del 50, al imitar a B.B., con labios que expresan mohínes enfurruñados, con los sweaters pegados al cuerpo, con su modo de caminar en "espiral", tienen la sensación de estar renovando el registro estético. También tienen la sensación de renovar los comportamientos, consagrando a través de la cobertura carnal de sus aspectos de mujeres fatales un cierto modo de vida. $E$ "brigittismo" introduce entonces algo profundo, una nueva visión del deseo femenino y su libertad, una nueva visión de la conquista estética, más directa más natural."

\footnotetext{
${ }^{29}$ Vigarello,G. (2009). Una sola Belleza, Triunfos de la estética, Triunfos de la Voluntad. En Du Seuil (Eds.), Historia de la Belleza (pp. 220-223). Buenos Aires: Editorial Ediciones Nueva Visión

${ }^{30}$ Vigarello,G. (2009). El "Más hermoso Objeto de Consumo". En Du Seuil (Eds.), Historia de la Belleza (pp. 230-242). Buenos Aires: Editorial Ediciones Nueva Visión

${ }^{31}$ Vigarello,G. (2009). El "Más hermoso Objeto de Consumo". En Du Seuil (Eds.), Historia de la Belleza (pp. 230-242). Buenos Aires: Editorial Ediciones Nueva Visión

${ }^{32}$ Vigarello,G. (2009). El "Más hermoso Objeto de Consumo". En Du Seuil (Eds.), Historia de la Belleza (pp. 230-242). Buenos Aires: Editorial Ediciones Nueva Visión
} 
Tendencia que indiscutiblemente cambió la forma de consumir y dió paso a nuevos motivos de elección de las mujeres, generando una transformación de 180 en el mundo de la lencería. Nuevos diseños que tenían como objetivo traducir atributos irracionales que se han deslizado hasta el momento: libertad, belleza más corporal, exterioridad, nueva estética, marcación de la silueta "delgadez"; que se debían a aquella ilusión que se imponía y se impone hoy en

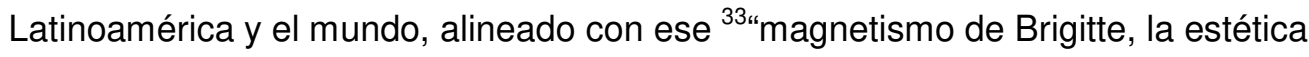
insensiblemente se vuelve saber "convertirse en sí mismo"'.

En conclusión claramente se instauro un nuevo formato de consumo femenino estético que cobró fuerza desde la década del 30 y fue mutando hasta la actualidad, pero siempre conservando e incentivando esa necesidad, ese motivo de elección de la mujer por remarcar su individualidad y libertad a través de la exteriorización corporal, de las prendas usadas y los accesorios lucidos, que menciona Sócrates ${ }^{34 “ l a ~ i m i t a c i o ́ n ~ e s ~ a d e c u a d a ~ p a r a ~ u n a ~ f o t o c o p i a d o r a, ~ p e r o ~}$ nunca dará lugar a la creación artística original que la vida humana debe afanarse en ser"

En donde el "hedonismo", tiempo libre y sobre todo, el consumo parecen triunfar durante la década de 1950, convirtiéndose en factores que arrastran al conjunto del universo estético

\subsection{Análisis del mercado de lencería latinoamericano}

Para evitar ambigüedad de lector y caer en subjetividades individuales es pertinente enmarcar y definir lo que entendemos por lencería y cuales son aquellos artículos que componen su oferta: ${ }^{35}$ “todas aquellas prendas femeninas de vestir que no se utilizan para salir o ser vistas por la calle. Equivale a la expresión coloquial ropa interior (que comprende el sostén, la braga, el slip, la camiseta, la combinación y ciertos tipos de body), si bien dentro de la lencería cabe incluir las prendas de dormir, como el camisón, pijama y la bata”.

\footnotetext{
${ }^{33}$ Vigarello,G. (2009). El "Más hermoso Objeto de Consumo". En Du Seuil (Eds.), Historia de la Belleza (pp. 230-242). Buenos Aires: Editorial Ediciones Nueva Visión

${ }^{34}$ Zygmunt, B. (2011), destino y Carácter. En Espasa Libros (Eds.), 44 Cartas desde el Mundo Líquido (pp.201-204). Barcelona: Editorial Espasa libros S.L.U.

${ }^{35}$ Riviére, M. (2014). Diccionario de la Moda Los Estilos del Siglo XX, Diversos (Eds.), (pp. 352). Editorial: Google Pay Libros.
} 
Al mismo tiempo Carolina Aubele en uno de sus libros define que ${ }^{36 \text { "existen }}$ muchos tipos de ropa interior que se distinguen por las necesidades y los usos finales. La finales. La industria de la ropa interior femenina está muy desarrollada y la oferta es muy es muy variada." 37"La ropa interior tiene tres usos básicos. El primero y elemental es el es el que explicita su nombre: es ropa para el interior y se usa debajo del exterior. Otras Otras veces se elige para que se vea debajo de la ropa, ya sea porque usamos prendas prendas transparentes o porque las prendas dejan ver un bretel o un elástico. Finalmente, Finalmente, está la que usamos para seducir cuando estamos dispuestas a quitarnos la ropa: en estos casos hablamos de etiqueta sexual".

Esta última definición es la que toma mayor fuerza al momento de definir lo comprendido por lencería, según el insight colectivo femenino, ya que es la que deja más expuesta a la mujer que busca ser aceptada ante la mirada del otro. Sin embargo, es pertinente no olvidar otra deducción antes de empezar a profundizar en lo referido propiamente dicho a las marcas, sus personalidades, formas de comunicación y tipo de mujer objetivo.

38“"En general, si hablamos de ropa interior sexy, lo importante es elegir lo que acompañe el estado de ánimo que se tiene y el personaje que se quiere jugar, sea inocente, sutil, romántico o perverso. Lo importante es sentirse cómoda y segura."

El comportamiento de este mercado es especial y claramente no se habla de commodities, ya que hay dos puntas que tienen que ir en sincronía total para no generar insatisfacción en el género femenino, la primera y principal es la complacencia comportamental de las clientes en las necesidades expuestas, y la segunda es la

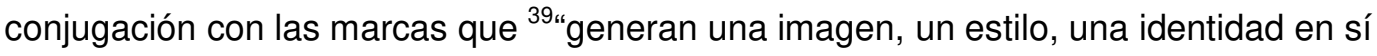
misma cargada de valores que se traducen en el producto. A veces, las prendas de un diseñador dependen menos de las telas, los cortes, los materiales y la calidad de confección, que, de la imagen de la marca, el posicionamiento del logo, las campañas y el arte realizado sobre una prenda y el packaging. La industria de la moda es una de las más competitivas del mundo. Cuando se paga una prenda de marca, lo que se paga es toda la inversión que la marca realiza para su posicionamiento y para crear el valor que tiene, de modo que, si la adquirimos, sintamos que pertenecemos, que podemos seducir,

\footnotetext{
${ }^{36}$ Aubele, C. (2010). La Ropa Interior. En Aguilar (Eds.), Secretos del Vestidor (pp. 114-120). Buenos Aires: Editorial Aguilar, Altea, Taurus, Alfaguara, S.A.

${ }^{37}$ Aubele, C. (2010). La Ropa Interior. En Aguilar (Eds.), Secretos del Vestidor (pp. 114-120). Buenos Aires: Editorial Aguilar, Altea, Taurus, Alfaguara, S.A.

${ }^{38}$ Aubele, C. (2010). La Ropa Interior. En Aguilar (Eds.), Secretos del Vestidor (pp. 114-120). Buenos Aires: Editorial Aguilar, Altea, Taurus, Alfaguara, S.A.

${ }^{39}$ Aubele, C. (2010). La Religión de las Marcas. En Aguilar (Eds.), Secretos del Vestidor (pp. 28-29). Buenos Aires: Editorial Aguilar, Altea, Taurus, Alfaguara, S.A.
} 
que tenemos estatus. A veces, cuando se compra una marca lo que se compra es el poder de comunicar a los gritos que se tiene la posibilidad de acceder a determinado nivel".

En la actualidad el mercado se compone por dos grandes grupos oferentes prendas: las marcas de ropa interior de "consumo masivo o uso diario" y las casas lencería femenina con diseño de autor como son llamadas en algunos países de Latinoamérica. De igual forma coinciden en su bajada conceptual generalmente y política empresarial en cuanto a talles ofertados se refiere, es decir ofrecen productos/artículos que no favorecen todos los tipos de cuerpo. Podemos tomar a Argentina como muestra de lo que pasa en otros países del territorio analizado, y 40“lo cierto es que un alto porcentaje del público femenino argentino no siente comodidad con la oferta que propone el mercado y dicha problemática no ha sido abordada en profundidad por los diseñadores nacionales"

\subsubsection{Análisis de grandes marcas}

- Victoria's Secret

\begin{tabular}{|c|c|}
\hline Logo & VICTORIA'S SECRET \\
\hline $\begin{array}{l}\text { Raíces de la } \\
\text { Marca }\end{array}$ & $\begin{array}{l}\text { "Empresa que nació en San Francisco EEUU por Roy Raymond quien la } \\
\text { vendió en } 1982 \text { a la corporación «The Limited Inc.» y ahora es propiedad de } \\
\text { su sucesora, la compañía Limited Brands - empresa que se dedica a la } \\
\text { producción de prendas de lencería y productos de belleza femenina." }{ }^{42 “ L a ~} \\
\text { idea es que los hombres se sintieran cómodos al momento de entrar al local } \\
\text { de lencería y comprarles a sus esposas o mujeres." }\end{array}$ \\
\hline
\end{tabular}

\footnotetext{
${ }^{40}$ Castro Telgado, C. (2011). Diseño de colección según los estereotipos corporales y la demanda de la sociedad argentina (Proyecto de Grado, Universidad de Palermo, Buenos Aires). Recuperada de http://fido.palermo.edu/servicios_dyc/proyectograduacion/archivos/431.pdf

${ }^{41}$ Wikipedia. (2017). Victoria's Secret. Recuperado el 07 de febrero del 2018 de https://es.wikipedia.org/wiki/Victoria's Secret.html

${ }^{42}$ Victoria's, S. (10 de abril del 2013). Introducción al femenino mundo de The Victoria's Secret (Mensaje en un blog). Recuperado de http://victoriassecr.blogspot.com.ar/.html
} 


\begin{tabular}{|c|c|}
\hline Target & $\begin{array}{l}\text { Mujeres de un NSE ABC1 - entre } 25 \text { a } 65 \text { años principalmente para las de } \\
\text { raza anglosajona, escandinava } 43 \text { “con poder adquisitivo, que les gusta } \\
\text { sentirse sexys, no pasar desapercibidas, sentirse cómodas y elegantes.” }\end{array}$ \\
\hline $\begin{array}{l}\text { Insigth de la } \\
\text { Marca }\end{array}$ & La mujer debe ser moderna, elegante, exclusiva y sensual. \\
\hline $\begin{array}{l}\text { Personalidad / } \\
\text { Razones para } \\
\text { creer }\end{array}$ & $\begin{array}{l}\text { Marca con diseños innovadores con alta calidad, sinónimo de elegancia, } \\
\text { buen gusto, sensualidad y exclusividad - que tiene como política y estrategia } \\
\text { comunicacional mostrarse a través de modelos famosas. }\end{array}$ \\
\hline $\begin{array}{l}\text { Canales de } \\
\text { Venta }\end{array}$ & $\begin{array}{l}\text { Tiendas en los principales centros Urbanos "capitales" y ciudades } \\
\text { importantes alrededor del mundo, tiendas libres de impuestos y venta por } \\
\text { Internet/ e-shop }\end{array}$ \\
\hline
\end{tabular}

Fuente: Tabla elaboración propia a partir de datos recolectados del blog de Victoria's Secret

- Leonisa

\begin{tabular}{|l|l|}
\hline Logo & $\begin{array}{l}\text { "4“"Empresa global, nació en Colombia en el año 1956. Fundada por los } \\
\text { hermanos Joaquín Urrea, Eduardo y Julio Ernesto. Crearon una empresa } \\
\text { especializada en prendas íntimas para la mujer con altos estándares de } \\
\text { calidad, resistencia y durabilidad de las prendas." }\end{array}$ \\
\hline Raíces de la & $\begin{array}{l}\text { 45“Niñas a partir de 14 años principalmente, adolescentes y Mujeres de } \\
\text { todas las edades con un NSE C3 - C2 y ABC1 - Para personas de todas } \\
\text { las razas, contextura física. (mujeres comunes)" }\end{array}$ \\
\hline Target & $\begin{array}{l}\text { Las mujeres somos seres en constante cambio que necesitamos } \\
\text { sentirnos entendidas, cómodas, sensuales, libres o atractivas según } \\
\text { el momento y la situación en la que nos encontremos. }\end{array}$ \\
\hline Insigth de la \\
Marca
\end{tabular}

${ }^{43}$ Victoria's, S. (10 de abril del 2013). Mercado Victoria's Secret (Mensaje en un blog). Recuperado el 07 de febrero del 2018 de http://victoriassecr.blogspot.com.ar/.html

${ }^{44}$ Leonisa. Compañía. (2017). Recuperado el 09 de febrero del 2018 de. http://www.leonisa.com/sp/.htm

${ }^{45}$ Leonisa. Compañía. (2017). Recuperado el 09 de febrero del 2018 de

http://leonisavirtual.leonisa.com/ventaporcatalogo/.htm. 


\begin{tabular}{|l|l|}
\hline $\begin{array}{l}\text { Razones para } \\
\text { Creer }\end{array}$ & $\begin{array}{l}\text { Calidad de prendas, que entiende que la mujer es un ser en cambio y } \\
\text { evolución constante. }\end{array}$ \\
\hline $\begin{array}{l}\text { Canales de } \\
\text { Venta }\end{array}$ & $\begin{array}{l}\text { Tienda Online, Hipermercados, Venta por catálogo, Tiendas especializadas } \\
\text { Leonisa, Tiendas libres de impuestos y Tiendas Outlet. Presencia en } \\
\text { Estados Unidos, España, Chile, Colombia, Costa Rica, Ecuador, } \\
\text { Guatemala, México, Panamá, Perú, Portugal y Puerto Rico. }\end{array}$ \\
\hline
\end{tabular}

- $\quad$ Calvin klein

\begin{tabular}{|c|c|}
\hline Logo & \\
\hline $\begin{array}{l}\text { Raíces de la } \\
\text { Marca }\end{array}$ & $\begin{array}{l}\text { Nació en New York EEUU en el año } 1968 \text { con diseños de abrigos } \\
\text { minimalistas que marcaron la tendencia de la moda de la década. }{ }^{46 \text { “La }} \\
\text { sencillez y elegancia de sus diseños de ropa interior convierte a la marca en } \\
\text { provocadora, sugerente y polémica de la industria”. }\end{array}$ \\
\hline Target & 47“Mujeres de NSE ABC1 - C2, a partir de los 25 años hasta los 75 años \\
\hline $\begin{array}{l}\text { Insigth de la } \\
\text { Marca }\end{array}$ & $\begin{array}{l}\text { 48“"La lencería es para todo tipo de mujer que decida estar a la vanguardia de } \\
\text { la moda- la elegancia, la sensualidad, el lucir prendas con estilo no tiene } \\
\text { límite de edad." }\end{array}$ \\
\hline $\begin{array}{l}\text { Personalidad / } \\
\text { Razones para } \\
\text { Creer }\end{array}$ & $\begin{array}{l}\text { Marca con calidad, con diseños sugestivos, a la vanguardia de la moda, } \\
\text { elegantes que reflejan la belleza de cualquier tipo de mujer sin importar raza } \\
\text { o edad. Marca que eligen las mujeres más emblemáticas del mundo. }\end{array}$ \\
\hline $\begin{array}{l}\text { Canales de } \\
\text { Venta }\end{array}$ & $\begin{array}{l}\text { Tiendas Calvin Klein, tiendas libres de impuestos en los principales centros } \\
\text { urbanos del mundo }\end{array}$ \\
\hline
\end{tabular}

${ }^{46}$ Vogue España. (s.f). Calvin Klein Diseñador. Recuperado el 09 de febrero del 2018 de http://www.vogue.es/moda/modapedia/disenadores/calvin-klein/266.htm ${ }^{47}$ Diario Clarín. (2017. Calvin Klein eligió a una modelo de 73 años para su campaña de ropa interior. Recuperado el 11 de febrero del 2018 de https://entremujeres.clarin.com/entremujeres/moda/lo-mastrendy/calvin-klein-eligio-modelo-73-anos-campana-ropa-interior 0 BkH-TM60l.html.htm ${ }^{48}$ Diario Clarín. (2017. Calvin Klein eligió a una modelo de 73 años para su campaña de ropa interior. Recuperado el 11 de febrero del 2018 de https://entremujeres.clarin.com/entremujeres/moda/lo-mastrendy/calvin-klein-eligio-modelo-73-anos-campana-ropa-interior 0 BkH-TM60l.html.htm 


\subsubsection{Análisis marcas con diseño de autor}

- Touché

\begin{tabular}{|c|c|}
\hline Logo & 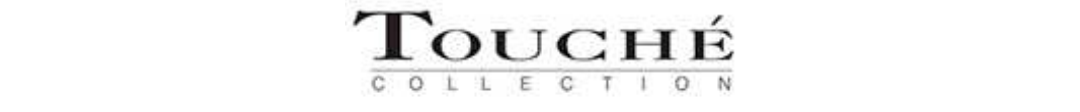 \\
\hline Raíces de la Marca & $\begin{array}{l}\text { 49"Marca Colombiana que nació en } 1987 \text { - diseño minimalista, } \\
\text { vanguardista, calidad, delicadeza de sus materiales, elegancia, enfoque } \\
\text { romántico, sensualidad y variedad de colores." }\end{array}$ \\
\hline Target & Mujeres entre 25 años y 45 años de NSE ABC1 y C2. \\
\hline Insigth de la Marca & $\begin{array}{l}\text { Las mujeres bellas, elegantes de hoy merecen la ropa interior con la } \\
\text { mejor calidad, y con diseños de vanguardia. }\end{array}$ \\
\hline $\begin{array}{l}\text { Personalidad / } \\
\text { Razones para } \\
\text { Creer }\end{array}$ & $\begin{array}{l}\text { Marca para mujeres que se consideran elegantes, delicadas, que buscan } \\
\text { prendas con calidad y diseños innovadores. }\end{array}$ \\
\hline Canales de Venta & $\begin{array}{l}\text { E-shop propio, "con presencia en más de } 25 \text { países a través de tiendas } \\
\text { propias, franquicias, cadenas departamentales y boutiques } \\
\text { especializadas" }\end{array}$ \\
\hline
\end{tabular}

- Jesús Fernández

\begin{tabular}{|l|l|}
\hline Logo & \\
\hline $\begin{array}{l}\text { Raíces de la } \\
\text { Marca }\end{array}$ & $\begin{array}{l}\text { 51"Marca Argentina creada en el 2003, en sus inicios marca que reciclaba } \\
\text { prendas, accesorios y, a su vez intervenía los diferentes tejidos y materiales } \\
\text { para obtener nuevas texturas. Con el fin de crear prendas únicas con un } \\
\text { enfoque en prendas Vintage inspiradas en la sensualidad y el diseño." }\end{array}$ \\
\hline
\end{tabular}

${ }^{49}$ Touché. (2017). Compañía. Recuperado el 10 de marzo del 2018 de http://touche.com.co/compania/.htm

50 Touché. (2017). Compañía. Recuperado el 10 de marzo del 2018 de http://touche.com.co/compania/.htm

${ }^{51}$ Castro, T.C. (2011). Lencería a Medida (tesis de grado). Recuperado el 23 de julio de

http://fido.palermo.edu/servicios dyc/proyectograduacion/archivos/431.pdf.htm 


\begin{tabular}{|c|c|}
\hline Target & 52“"Mujeres entre 20 a 55 años de NSE ABC1 - C2” \\
\hline $\begin{array}{l}\text { Insigth de la } \\
\text { Marca }\end{array}$ & $\begin{array}{l}\text { Las mujeres glamorosas buscan prendas exclusivas, de diseño, finas que } \\
\text { resalten su sensualidad y belleza. }\end{array}$ \\
\hline $\begin{array}{l}\text { Personalidad / } \\
\text { Razones para } \\
\text { Creer }\end{array}$ & $\begin{array}{l}\text { Glamour, sensualidad, exclusividad, diseños originales que conjugan la } \\
\text { atemporalidad, calidad, que hace única a la mujer que usa sus prendas. }\end{array}$ \\
\hline Canales de Venta & $\begin{array}{l}\text { E-shop propio y cuenta con locales propios en La ciudad autónoma de } \\
\text { Buenos Aires Argentina. }\end{array}$ \\
\hline
\end{tabular}

${ }^{52}$ Castro, T.C. (2011). Lencería a Medida (tesis de grado). Recuperado el 23 de julio de http://fido.palermo.edu/servicios dyc/proyectograduacion/archivos/431.pdf.htm 


\section{RELEVAMIENTO DEL PENSAMIENTO DE LA DEMANDA}

\subsection{Encuestas de opinión a la mujer actual sobre la lencería, usos y necesidades}

En el capítulo anterior del presente trabajo de tesis se han planteado diferentes temáticas argumentales e hipótesis sobre el pensamiento de la mujer acerca del concepto de belleza, mundo de la moda, el mercado de lencería femenina y la forma en el que el mercado de interés (lencería femenina) se desarrolla actualmente, con el objetivo de dar soporte a la creación y posicionamiento de la marca Lo que dice Eva.

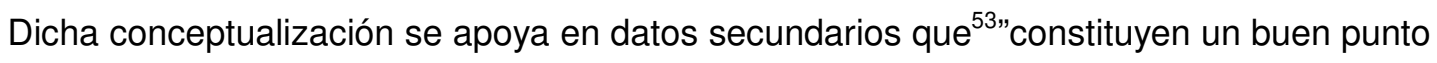
de inicio para la investigación y con frecuencia ayudan a definir problemas y objetivos de investigación. Sin embargo, en la mayoría de los casos la empresa también debe recabar datos primarios", al igual que lo debe hacer un investigador académico para darle cierre y encontrar conclusiones asertivas que den forma y sustento al trabajo de investigación esbozado.

En consecuencia, se ha incluido en el presente trabajo de tesis una investigación por encuestas, ${ }^{54 " m e ́ t o d o ~ m a ́ s ~ u t i l i z a d o ~ p a r a ~ r e c a b a r ~ d a t o s ~ p r i m a r i o s, ~ e s ~ l a ~ e s t r a t e g i a ~ m a ́ s ~}$ adecuada para reunir información descriptiva". Para ello se diseñó una encuesta (anexo 1) realizada al sexo femenino con edad superior a15 años, dirigidas solamente a Latinoamericanas.

A continuación, se mostrarán los resultados, referidos al pensamiento de las encuestadas en cuanto a: nivel de satisfacción del mercado actual de lencería, marcas, actitudes, preferencias, usos y comportamientos de compra. Información complementaria que permitirá construir los capítulos siguientes referidos a la conceptualización/perfil de la marca y desarrollo de la estrategia comercial y posicionamiento.

\footnotetext{
${ }^{53}$ Kotler, P \& Armstrong, G. (2012). Administración de la información de marketing para conocer a los clientes. En Pearson Education (Eds.), Marketing (pp.96-107). Ciudad de México: Pearson Editorial.

${ }^{54}$ Kotler, P \& Armstrong, G.(2012).Marketing Real. En Pearson Education (Eds.), Marketing (pp.108-114). Ciudad de México: Pearson Editorial.
} 


\subsection{Datos generales del relevamiento}
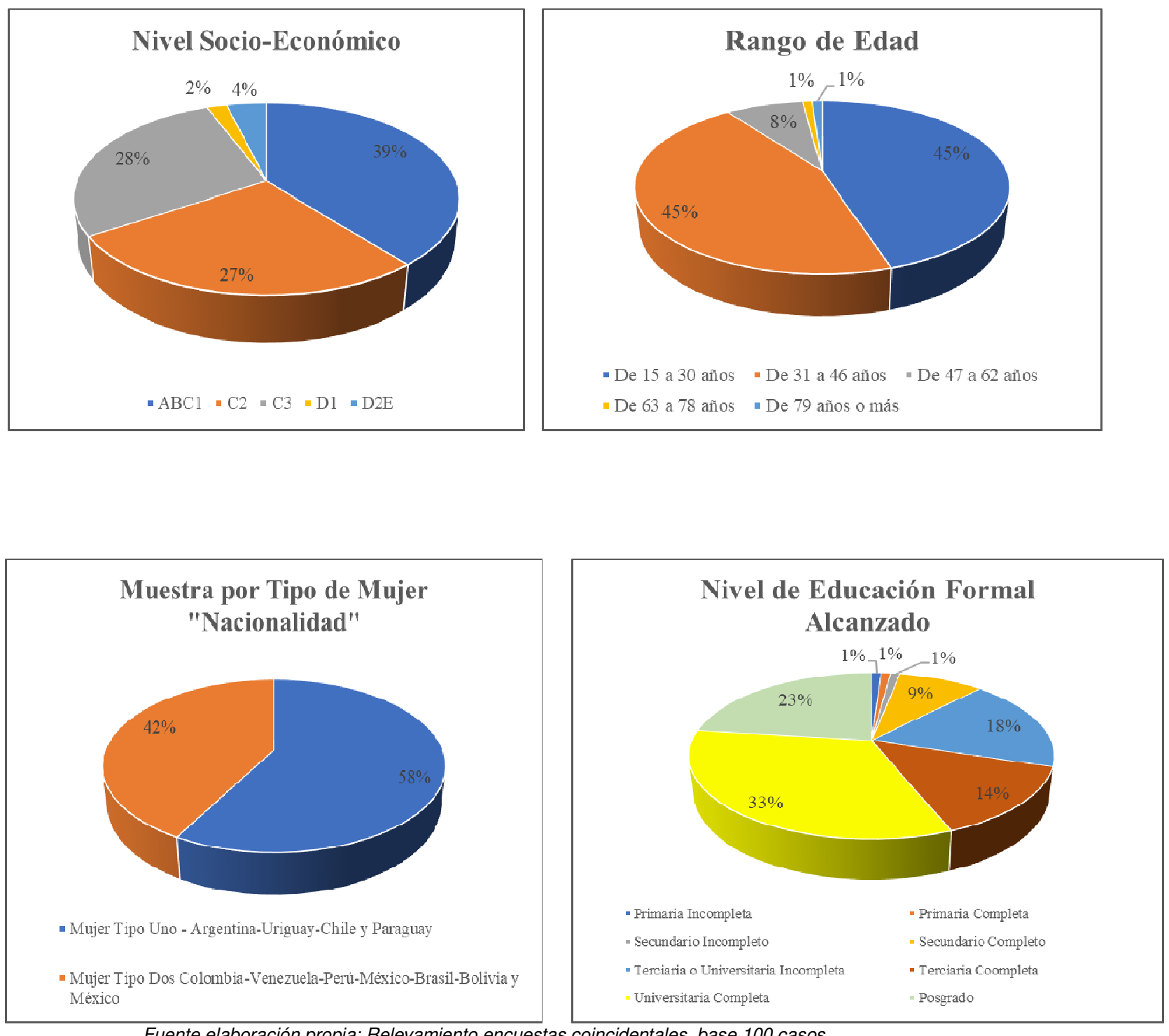

Fuente elaboración propia: Relevamiento encuestas coincidentales, base 100 casos

2.3 Nivel de satisfacción - preguntas de la encuesta.

¿Actualmente usted encuentra satisfechas todas sus necesidades en

lo referido a lencería femenina, por las marcas que ofrece el mercado? 


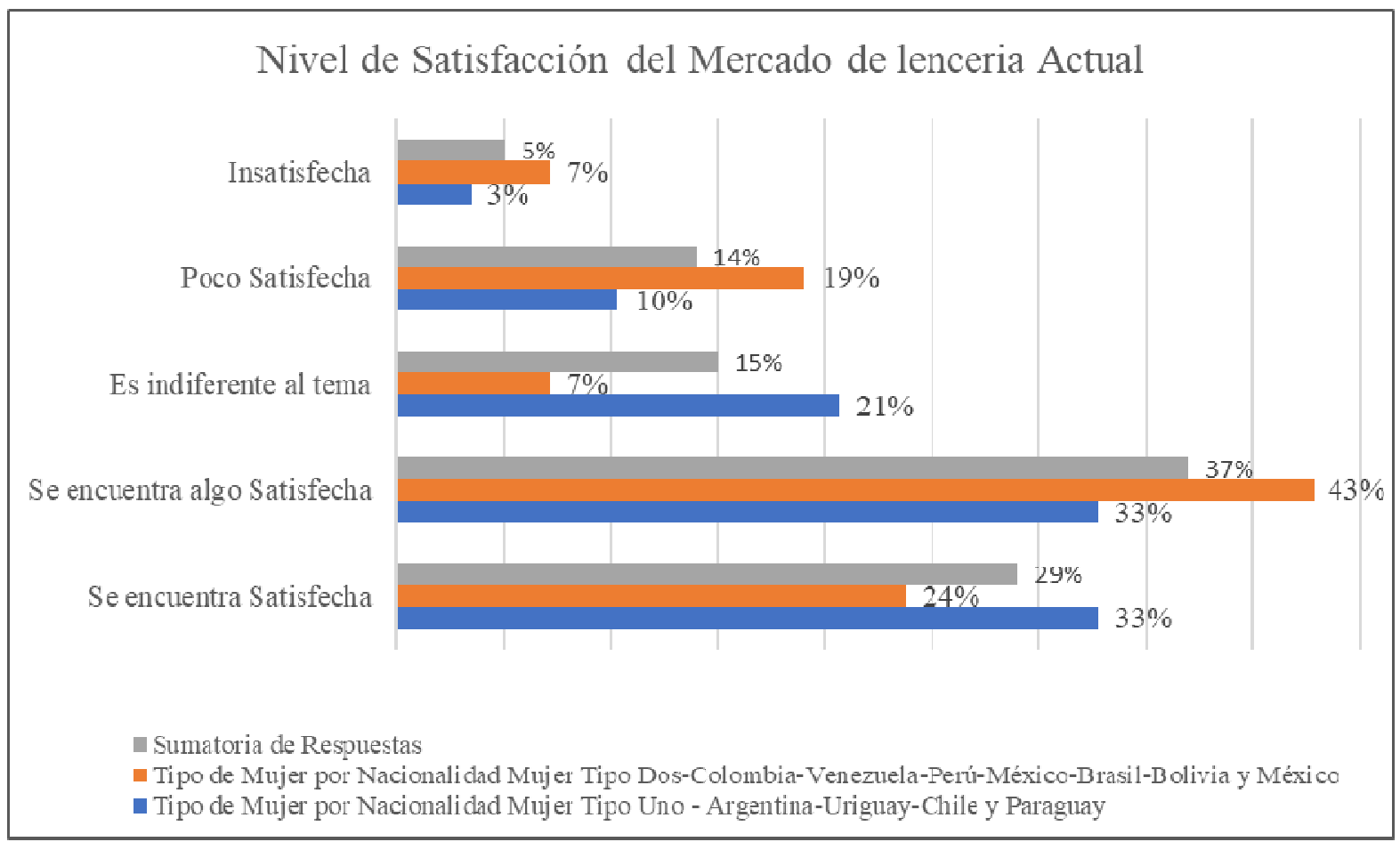

Fuente elaboración propia: Relevamiento encuestas coincidentales, base 100 casos

Los porcentajes que muestran mayor relevancia es de la respuesta se encuentra algo satisfecha con una sumatoria de $37 \%$ del total de mujeres consultadas de las distintas nacionalidades, siendo mayor las mujeres tipo (Dos+Tres) con un 43\%, las tipo

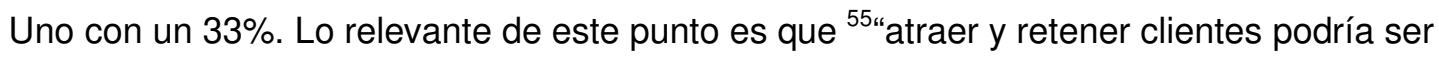
una tarea difícil. A menudo los clientes se enfrentan a una selección confusa de productos y servicios para elegir." Mostrando claramente que las clientas no terminan de estar fidelizadas por las marcas actuales y completamente satisfechas con los productos existentes por los diversos mercados actuales. Si hacemos foco en las respuestas (insatisfecha, poco satisfecha, es indiferente al tema) vemos que el 34\% de las mujeres encuestadas ha respondido alguna de estas, por lo cual se puede concluir a priori que existen posibilidades para la marca Lo que dice Eva de desempeñarse con éxito.

Finalmente, la definición se refuerza con la prueba estadística, mostrando que no hay certeza de ocurrencia que la respuesta elegida sea: Se encuentra Satisfecha, (shi=6,307 y $p>0,05$ ), con lo cual se hace necesario ampliar el análisis, por ello se va a complementar con el análisis de las siguientes afirmaciones:

\footnotetext{
${ }^{55}$ Kotler, P \& Armstrong, G. (2012). Establecimiento de las relaciones con el cliente. En Pearson Education (Eds.), Marketing (pp.12-13). Ciudad de México: Pearson Editorial.
} 


\subsubsection{Relación tipo de mujer con las marcas}

"Le voy a leer una serie de afirmaciones relacionadas con prendas/mercado de lencería femenina, le pido por favor que indique su grado de acuerdo o desacuerdo con cada una de ellas" textual encuesta.

Para enriquecer el análisis se decidió hacer el cruce con la pregunta: En su opinión siente usted que las marcas de lencería femenina son excluyentes con mujeres de su tipo. Si o no.

\begin{tabular}{|c|c|c|c|c|}
\hline \multicolumn{2}{|c|}{$\begin{array}{l}\text { En su opinión siente usted que las marcas de lencería femenina } \\
\text { son excluyentes con mujeres de su tipo }\end{array}$} & \multirow{2}{*}{$\begin{array}{c}\mathrm{Si} \\
45 \%\end{array}$} & \multirow{2}{*}{$\begin{array}{l}\text { No } \\
19 \%\end{array}$} & \multirow{2}{*}{$\begin{array}{l}\text { Total } \\
28 \%\end{array}$} \\
\hline \multirow{4}{*}{$\begin{array}{l}\text { Las marcas de lencería proponen un tipo de } \\
\text { mujer perfecta (piernas alargadas, estilizada, } \\
\text { joven) que hace sentir frustración a la } \\
\text { mayoría de las mujeres }\end{array}$} & Muy de Acuerdo & & & \\
\hline & De acuerdo & $52 \%$ & $45 \%$ & $47 \%$ \\
\hline & $\begin{array}{l}\text { Ni de acuerdo, ni en } \\
\text { desacuerdo }\end{array}$ & $3 \%$ & $21 \%$ & $15 \%$ \\
\hline & En desacuerdo & $0 \%$ & $15 \%$ & $10 \%$ \\
\hline Total Casos Relevados & & 33 & 67 & 100 \\
\hline Total Peso Porcentual & & $100 \%$ & $100 \%$ & $100 \%$ \\
\hline
\end{tabular}

Lo interesante del cuadro es que el $67 \%$ de las mujeres encuestadas piensan que las marcas no son excluyentes con mujeres de su tipo, pero lo llamativo es que el $45 \%$ de ellas dicen estar de acuerdo con la hipótesis que las marcas de lencería femenina proponen un tipo de mujer perfecta, un estilo de belleza que las hace sentir frustración. El 19\% de ellas dice estar muy de acuerdo, al igual que las que respondieron que SI se sienten excluidas por las marcas de lencería, asintieron en un $45 \%$ estar muy de acuerdo, y un $52 \%$ de acuerdo con la hipótesis de las marcas. Lo cual indica la afirmación propuesta es válida. Sustento estadístico (shi $=15,20$ y $\mathrm{p}<0,00)$.

En consecuencia, presentamos otra tabla donde se muestra que la mujer latina se siente alejada de dicho prototipo de belleza que promueven las marcas. Siendo que de 67 casos de mujeres que respondieron que no se sienten excluidas por las marcas, el $57 \%$ de ellas está de acuerdo que se encuentra alejada de ese modelo de belleza promovido, más el 19\% que dicen estar muy de acuerdo, sustento estadístico (shi=9,28 y $\mathrm{p}<0,049)$ : 


\begin{tabular}{|c|c|c|c|c|}
\hline \multicolumn{2}{|c|}{$\begin{array}{c}\text { Siente usted que las marcas de lencería } \\
\text { femenina son excluyentes con mujeres de su } \\
\text { tipo }\end{array}$} & \multirow{2}{*}{$\begin{array}{l}\mathrm{Si} \\
45 \%\end{array}$} & \multirow{2}{*}{$\begin{array}{l}\text { No } \\
19 \%\end{array}$} & \multirow{2}{*}{$\begin{array}{l}\text { Total } \\
28 \%\end{array}$} \\
\hline \multirow{5}{*}{$\begin{array}{l}\text { La mayoría de las mujeres } \\
\text { se encuentra alejada del } \\
\text { modelo de belleza perfecta } \\
\text { que promueven las marcas } \\
\text { de lencería }\end{array}$} & Muy de Acuerdo & & & \\
\hline & De acuerdo & $39 \%$ & $57 \%$ & $51 \%$ \\
\hline & $\begin{array}{l}\text { Ni de acuerdo, ni } \\
\text { en desacuerdo }\end{array}$ & $6 \%$ & $16 \%$ & $13 \%$ \\
\hline & En desacuerdo & $9 \%$ & $6 \%$ & $7 \%$ \\
\hline & $\begin{array}{l}\text { Muy en } \\
\text { desacuerdo }\end{array}$ & $0 \%$ & $1 \%$ & $1 \%$ \\
\hline \multicolumn{2}{|l|}{ Total Casos Relevados } & $33 \%$ & $67 \%$ & $100 \%$ \\
\hline
\end{tabular}

Ahora bien, para terminar de cerrar el análisis del nivel de satisfacción que presenta la mujer latina, y poder concluir vamos a presentar otra tabla que tienen relación con el producto terminado "prendas" que comercializan:

\begin{tabular}{|ccccc|}
\hline $\begin{array}{c}\text { En su opinión siente usted que las marcas de } \\
\text { lencería femenina son excluyentes con mujeres } \\
\text { de su tipo }\end{array}$ & $\mathrm{Si}$ & No & Total \\
\hline & Muy de Acuerdo & $48 \%$ & $15 \%$ & $26 \%$ \\
\cline { 2 - 5 } & De acuerdo & $27 \%$ & $40 \%$ & $36 \%$ \\
\cline { 2 - 5 } $\begin{array}{c}\text { Las prendas de mejor diseño } \\
\text { calidad son para personas } \\
\text { adineradas }\end{array}$ & $\begin{array}{c}\text { Ni de acuerdo, ni } \\
\text { en desacuerdo }\end{array}$ & $18 \%$ & $21 \%$ & $20 \%$ \\
\cline { 2 - 5 } & En desacuerdo & $6 \%$ & $16 \%$ & $13 \%$ \\
\cline { 2 - 5 } & En desacuerdo & $0 \%$ & $7 \%$ & 100 \\
\hline Total Casos Relevados & 33 & 67 & $100 \%$ \\
\hline Total Peso Porcentual & $100 \%$ & $100 \%$ & \\
\hline
\end{tabular}

Fuente elaboración propia: Relevamiento encuestas coincidentales, base 100 casos

El $40 \%$ del $67 \%$ de mujeres que responde que no se sienten excluidas por las marcas de lencería femenina, dice estar de acuerdo con la afirmación que las prendas de mejor diseño y calidad son para personas adineradas. Mientras que el $48 \%$ de mujeres del 33\%, que respondió sentirse excluida respondió estar muy de acuerdo con la afirmación analizada. Sustento estadístico ( $(\mathrm{shi}=14,98$ y $\mathrm{p}<0,03)$ : 
Con base en los argumentos presentados, se puede decir que la mujer latina actual, en su gran mayoría no se siente excluida por las marcas de lencería, su forma de comunicar sus productos y el prototipo de belleza que promueven. Pero esto no quiere decir que la ecuación sea perfecta, ya que se deja ver a través de las encuestas realizadas que: la mujer latina a pesar de sentirse incluida por las marcas, no está de acuerdo con el prototipo de belleza promulgado por la industria, piensan que la mayoría de las mujeres están alejadas de dicho modelo y que se les causa frustración, además que las prendas de mejor calidad y diseño son para personas adineradas, siendo esto argumento suficiente para concluir que el nivel de satisfacción de ellas no está del todo cubierto.

\subsection{Atributos de la marca según la consumidora latinoamericana}

En esta parte del presente trabajo se ha de presentar el pensamiento de la mujer latina sobre los atributos que para ellas debe tener una marca, para ello se utilizaron 4 preguntas contenidas en la encuesta realizada, a raíz que las 56،marcas representan las percepciones y los sentimientos de los consumidores acerca del producto y su desempeño, es decir, todo lo que el producto significa para los consumidores. Como señaló una ocasión un mercadólogo muy respetado: "los productos se crean en la fábrica, pero las marcas se crean en la mente". Jason Kilar, director del, director general del servicio de video en línea Hulu añade: "la marca es lo que la gente dice de ti cuando no estas presente".

Como punto de partida se consultó sobre las marcas presentes en los distintos mercados/países donde vivían las mujeres encuestadas:

\subsubsection{Top of mind de marcas de lencería para la mujer latina}

\section{¿Cuáles son las 3 marcas de lencería femenina que considera usted que satisfacen sus necesidades?, siendo 1 la más importante y 3 la menos importante.}

\footnotetext{
${ }^{56}$ Kotler, P \& Armstrong, G. (2012). Estrategia de asignación de marcas: creación de marcas fuertes. En Pearson Education (Eds.), Marketing (pp.243-246). Ciudad de México: Pearson Editorial.
} 


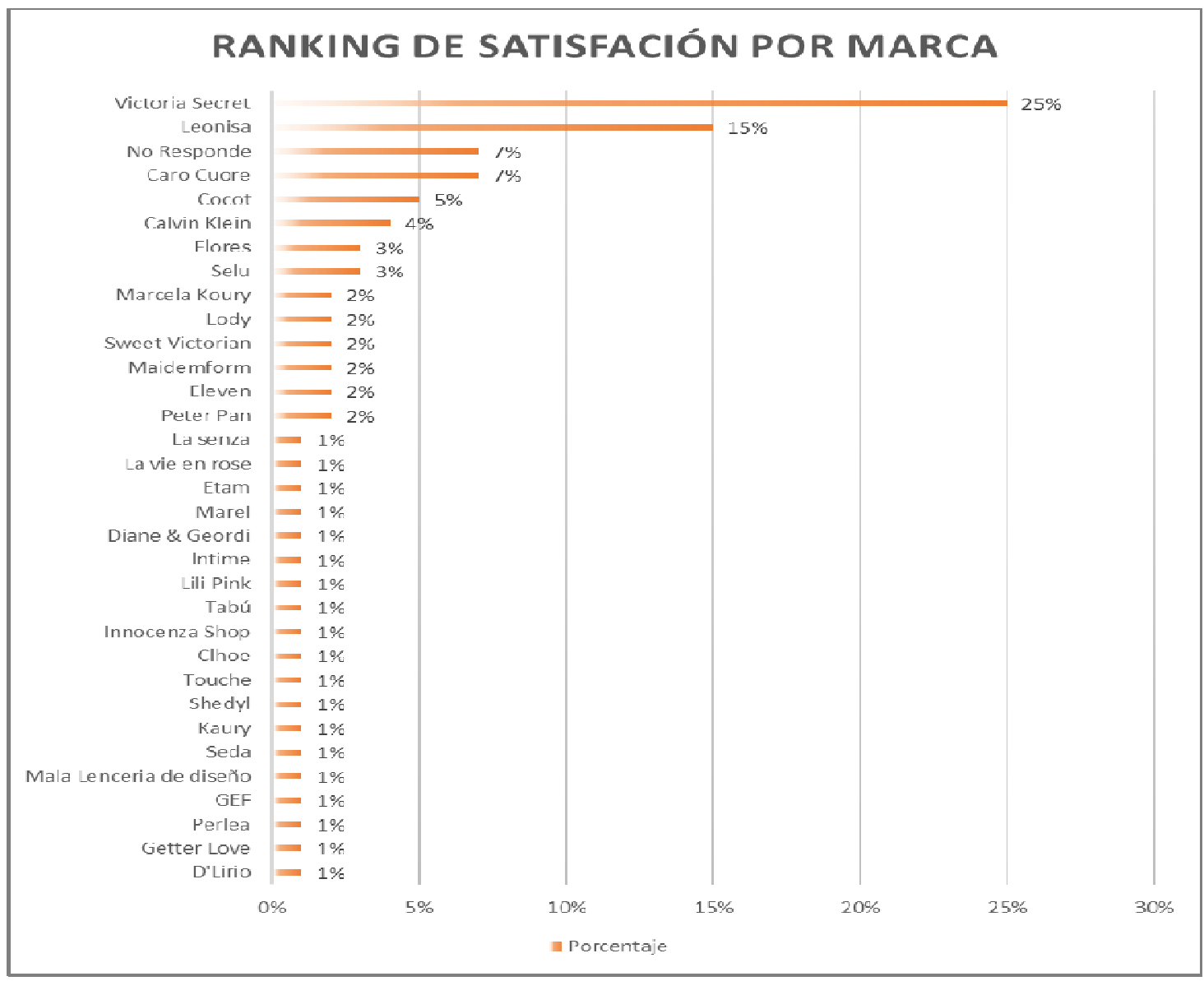

Fuente elaboración propia: Relevamiento encuestas coincidentales, base 100 casos

\subsubsection{Mención de marcas por grupo de mujeres de interés:}

\begin{tabular}{|l|c|c|c|}
\hline $\begin{array}{c}\text { ¿Cuáles son las } 3 \text { marcas de lencería } \\
\text { Femenina que considera usted que } \\
\text { satisfacen sus necesidades }\end{array}$ & $\begin{array}{c}\text { Mujer Tipo Uno - } \\
\text { Argentina- } \\
\text { Uruguay-Chile y } \\
\text { Paraguay }\end{array}$ & $\begin{array}{c}\text { Mujer Tipo Dos } \\
\text { Colombia- } \\
\text { Venezuela-Perú- } \\
\text { México-Brasil- } \\
\text { Bolivia y México }\end{array}$ & Total \\
\hline Victoria Secret & $15 \%$ & $10 \%$ & $25 \%$ \\
\hline Leonisa & $0 \%$ & $15 \%$ & $15 \%$ \\
\hline Caro Cuore & $6 \%$ & $1 \%$ & $7 \%$ \\
\hline No Responde & $4 \%$ & $3 \%$ & $7 \%$ \\
\hline Otras Marcas $\quad$ Total & $33 \%$ & $13 \%$ & $46 \%$ \\
\hline
\end{tabular}

Fuente elaboración propia: Relevamiento encuestas coincidentales, base 100 casos

\subsubsection{Atributos de marca de lencería femenina para la mujer latina}

Para encontrar los atributos que tiene que tener una marca según las mujeres latinas, se utilizó la siguiente pregunta, mediante una encuesta coincidental a mujeres sin 
importar su edad ni su nacionalidad, solo eran excluidas las que no eran de nacionalidad latina:

Pregunta utilizada: De la siguiente lista de atributos que debe inspirar una marca de lencería, ¿Cuáles considera usted que debe tener la marca que elegiría?, mencione cinco, enumérelas del 1 al 5 , siendo 1 la más importante y 5 la menos importante para usted.

\begin{tabular}{|c|c|c|c|c|}
\hline Preferencia & Atributo & $\begin{array}{c}\text { Mujer Tipo Uno - } \\
\text { Argentina-Uruguay- } \\
\text { Chile y Paraguay }\end{array}$ & $\begin{array}{c}\text { Mujer Tipo Dos Colombia- } \\
\text { Venezuela-Perú-México- } \\
\text { Brasil-Bolivia y México }\end{array}$ & Total \\
\hline Primero & Calidad & $33 \%$ & $48 \%$ & $39 \%$ \\
\hline Segundo & Confort & $19 \%$ & $31 \%$ & $24 \%$ \\
\hline Tercero & Diseño & $19 \%$ & $17 \%$ & $18 \%$ \\
\hline Cuarto & Buen Precio & $29 \%$ & $10 \%$ & $21 \%$ \\
\hline Quinto & Sensualidad & $22 \%$ & $14 \%$ & $19 \%$ \\
\hline
\end{tabular}

Para la construcción de la tabla se seleccionaron aquellos atributos que fueron destacados por las mujeres encuestadas, de un grupo de 11 respuestas pre-establecidas de antemano en el cuestionario. Para facilitar el análisis se agruparon las distintas nacionalidades en dos grandes grupos que guardan similitud de rasgos fenotípicos y comportamentales que construyen su propia subjetividad de opinión, mostrando que existe una escala de importancia. El total finalmente es el peso porcentual de la respuesta mostrada dentro de esos 11 atributos expuestos inicialmente.

\subsubsection{Relación marca - precio}

La relación precio-marca es esencial para entender cuál es el nivel perfecto donde se maximiza parte del beneficio para el cliente en relación con una marca. Aún más relevante y enriquecedor resulta ser, cuando es destacado por las personas encuestadas, como sucede en el presente trabajo de tesis, ya que fue destacado como atributo esencial de una marca de lencería femenina. En post de encontrar la ecuación perfecta que a su vez genere ese nivel de rentabilidad para el negocio/marca a construir. Se tomó como parámetro comparativo a dos grandes marcas internacionales y el aspiracional que generan las mismas con relación al precio que ofertan sus diseños, con el fin de generar otra herramienta 
que permita construir una marca exitosa, llegando a la siguiente relación mostrada a través del siguiente cuadro:

\begin{tabular}{|c|c|c|c|c|c|c|}
\hline \multirow{2}{*}{$\begin{array}{l}\text { Grado de concordancia con la } \\
\text { afirmación: Las prendas de } \\
\text { lencería femenina de marcas } \\
\text { internacionales como Victoria's } \\
\text { Secret, Calvin Klein son las que } \\
\text { mejor calidad y diseños tienen: }\end{array}$} & \multicolumn{5}{|c|}{$\begin{array}{c}\text { Las prendas de mejor diseño y calidad son para } \\
\text { personas adineradas }\end{array}$} & \multirow[b]{2}{*}{ Total } \\
\hline & $\begin{array}{l}\text { Muy de } \\
\text { Acuerdo }\end{array}$ & $\begin{array}{l}\text { De } \\
\text { acuerdo }\end{array}$ & $\begin{array}{c}\text { Ni de } \\
\text { acuerdo, ni } \\
\text { en } \\
\text { desacuerdo }\end{array}$ & $\begin{array}{c}\text { En } \\
\text { desacuerdo }\end{array}$ & $\begin{array}{c}\text { En } \\
\text { desacuerdo }\end{array}$ & \\
\hline Completamente de acuerdo & $58 \%$ & $25 \%$ & $5 \%$ & $15 \%$ & $20 \%$ & $28 \%$ \\
\hline Parcialmente de acuerdo & $15 \%$ & $47 \%$ & $20 \%$ & $46 \%$ & $40 \%$ & $33 \%$ \\
\hline $\begin{array}{l}\text { Ni acuerdo, ni en } \\
\text { desacuerdo }\end{array}$ & $19 \%$ & $19 \%$ & $50 \%$ & $15 \%$ & $20 \%$ & $25 \%$ \\
\hline $\begin{array}{l}\text { Parcialmente en } \\
\text { desacuerdo }\end{array}$ & $0 \%$ & $8 \%$ & $15 \%$ & $23 \%$ & $0 \%$ & $9 \%$ \\
\hline $\begin{array}{l}\text { Completamente en } \\
\text { desacuerdo }\end{array}$ & $8 \%$ & $0 \%$ & $10 \%$ & $0 \%$ & $20 \%$ & $5 \%$ \\
\hline
\end{tabular}

Fuente elaboración propia: Relevamiento encuestas coincidentales, base 100 casos (shi=38,23 y p <0,03)

Lo relevante de la tabla enunciada es como las mujeres latinas opinan que las prendas con mejor diseño y calidad de lencería son de marcas internacionales y son para personas adineradas, y pertenecen a grandes marcas, como a las que se les hace mención.

\subsection{Motivos de elección que movilizan a la mujer latina}

El objetivo de la presente sección del trabajo es presentar patrones, similitudes en el pensamiento femenino encuestado, que sean determinantes al momento de compra de la lencería. Es esencial recabar la mayor cantidad de información que permita construir parte de los pilares y de las bases ideológicas que aporten a la construcción de la personalidad de la marca Lo que dice Eva. ${ }^{57 " L a}$ idea es que las marcas también tienen personalidades, y que los consumidores probablemente eligen las marcas cuyas personalidades coinciden con la suya", para ello se construyeron preguntas objetivas implementadas a las mujeres latinas a través la encuesta coincidental aplicada.

Para lograr un análisis efectivo de la información recabada a través de las encuestas, es preciso entender previamente que existe otro concepto que aporta a la construcción de cualquier marca, y es el estilo de vida de cualquier ser humano que

\footnotetext{
${ }^{57}$ Kotler, P \& Armstrong, G. (2012). Mercados de consumo y comportamiento de compra. En Pearson Education (Eds.), Marketing (pp.132-163). Ciudad de México: Pearson Editorial.
} 
58،incluye algo más que la clase social o la personalidad de la mujer: perfila su patrón completo de participación en el mundo e interacción con éste.

Cuando se utiliza de forma cuidadosa, el concepto de estilo de vida puede ayudar a los mercadólogos a entender los valores cambiantes de los consumidores y la manera en que afectan el comportamiento de compra. Los consumidores no sólo compran productos, sino que adquieren los valores del estilo de vida que representan tales productos".

\subsubsection{Tipo de lencería más usada}

Pregunta Utilizada: Mencione el orden de preferencia del tipo de lencería que elige usualmente al momento de efectuar la compra. Siendo 1 la opción más importante y 5 la menos importante para usted.

Tabla - Medición por tipo de Lencería

\begin{tabular}{|c|c|c|c|l|}
\hline Preferencia & Tipo de Lencería & $\begin{array}{c}\text { Mujer Tipo Uno - } \\
\text { Argentina- } \\
\text { Uruguay-Chile- } \\
\text { Paraguay }\end{array}$ & $\begin{array}{c}\text { Mujer Tipo Dos } \\
\text { Colombia- } \\
\text { Venezuela-Perú- } \\
\text { México-Brasil- } \\
\text { Bolivia-México }\end{array}$ & Total \\
\hline Primera & Uso diario, cómoda & $78 \%$ & $88 \%$ & $82 \%$ \\
\hline Segunda & Sensual de diseño & $24 \%$ & $52 \%$ & $36 \%$ \\
\hline Tercera & Deportiva & $28 \%$ & $36 \%$ & $31 \%$ \\
\hline Cuarta & Pijamas, ropa de descanso & $33 \%$ & $31 \%$ & $32 \%$ \\
\hline Quinta & Reductora, para modelar el cuerpo & $52 \%$ & $57 \%$ & $54 \%$ \\
\hline
\end{tabular}

Fuente elaboración propia: Relevamiento encuestas coincidentales, base 100 casos

Lo interesante a destacar de la tabla anterior es que, para los dos grandes grupos de mujeres armados con características similares entre ellas, entendiendo su estilo de vida, y los rasgos que llevan a entender que tienen personalidades similares. Vemos que las prendas que más les incentiva comprar es la lencería de uso diario, cómoda; el total de la tercera columna es el peso porcentual parcial para cada respuesta tabulada tienen sobre la tabulación individual de las cinco respuestas posibles.

Ahora bien, en la misma línea de información a analizar miremos la frecuencia de compra, para ello se implementó la siguiente pregunta, cuyas

\footnotetext{
${ }^{58}$ Kotler, P \& Armstrong, G. (2012). Mercados de consumo y comportamiento de compra. En Pearson Education (Eds.), Marketing (pp.132-163). Ciudad de México: Pearson Editorial.
} 
respuestas para la tabulación lo haremos con el tipo de lencería que prefiere para enriquecer la información resultante:

\subsubsection{Frecuencia de compra de la mujer latina}

Pregunta: Por favor, ¿Mencione la frecuencia con la que usted suele comprar lencería?

\begin{tabular}{|c|c|c|c|c|c|c|c|}
\hline \multirow{2}{*}{\multicolumn{2}{|c|}{$\begin{array}{l}\text { ¿Mencione la frecuencia } \\
\text { con la que usted suele } \\
\text { comprar lencería? }\end{array}$}} & \multicolumn{5}{|c|}{$\begin{array}{l}\text { Al momento de comprar lencería para usted, mencione el orden de } \\
\text { preferencia del tipo de lencería que elige usualmente al momento de } \\
\text { efectuar la compra. Siendo } 1 \text { la opción más importante y } 5 \text { la menos } \\
\text { importante para usted. }\end{array}$} & \multirow{3}{*}{$\begin{array}{l}\text { Tota } \\
4 \%\end{array}$} \\
\hline & & & & $\begin{array}{l}\text { Lencería } \\
\text { reductora, }\end{array}$ & Pijamas, ropa & Lencería & \\
\hline \multirow{4}{*}{$\begin{array}{c}\text { ¿Mencione } \\
\text { la } \\
\text { frecuencia } \\
\text { con la } \\
\text { usted que } \\
\text { suele } \\
\text { comprar } \\
\text { lencería? }\end{array}$} & $\begin{array}{c}\text { Cada mes o } \\
\text { menos }\end{array}$ & $2 \%$ & $18 \%$ & $0 \%$ & $0 \%$ & $0 \%$ & \\
\hline & $\begin{array}{c}\text { Cada dos } \\
\text { meses }\end{array}$ & $16 \%$ & $18 \%$ & $50 \%$ & $100 \%$ & $0 \%$ & $18 \%$ \\
\hline & $\begin{array}{c}\text { Cada tres } \\
\text { meses }\end{array}$ & $32 \%$ & $18 \%$ & $25 \%$ & $0 \%$ & $0 \%$ & $29 \%$ \\
\hline & $\begin{array}{l}\text { Cada seis } \\
\text { meses o } \\
\text { mas }\end{array}$ & $50 \%$ & $45 \%$ & $25 \%$ & $0 \%$ & $100 \%$ & $49 \%$ \\
\hline \multicolumn{2}{|c|}{ Total Casos } & $82 \%$ & $11 \%$ & $4 \%$ & $1 \%$ & $2 \%$ & 100 \\
\hline
\end{tabular}

Fuente elaboración propia: Relevamiento encuestas coincidentales, base 100 casos (shi=13,23 y p <0,035)

El $82 \%$ de las mujeres que respondieron como primera opción de compra la lencería de uso diario, coincide un $50 \%$ de ellas que su frecuencia de compra es cada seis meses o más, y el $32 \%$ cada tres meses, que sería el foco de la marca. La frecuencia mensual relevada es un dato que la marca debe revisar, como indicador relevante para el funcionamiento de su negocio.

La siguiente incógnita que se presenta y no es menor para las mujeres al momento de decidir por una prenda (marca), y actúa de forma complementaria de la multiculturalidad que las atraviesa, costumbres y rasgos fenotípicos, es en donde se informan regularmente las mujeres para tomar decisiones de las prendas a comprar, a quien le deben comprar, y a donde deben dirigirse. Este es un punto que consideran los mercadólogos y analizan, ${ }^{59}$ “la forma en que los estímulos se convierten en respuesta dentro de la caja negra del consumidor". Para ello se les pregunto:

\subsubsection{Sondeo de información de producto. ¿Cuáles son los medios/lugares que usted consulta regularmente para enterarse del mundo de la lencería y sus marcas?}

\footnotetext{
${ }^{59}$ Kotler, P \& Armstrong, G. (2012). Mercados de consumo y comportamiento de compra. En Pearson Education (Eds.), Marketing (pp.132-163). Ciudad de México: Pearson Editorial.
} 


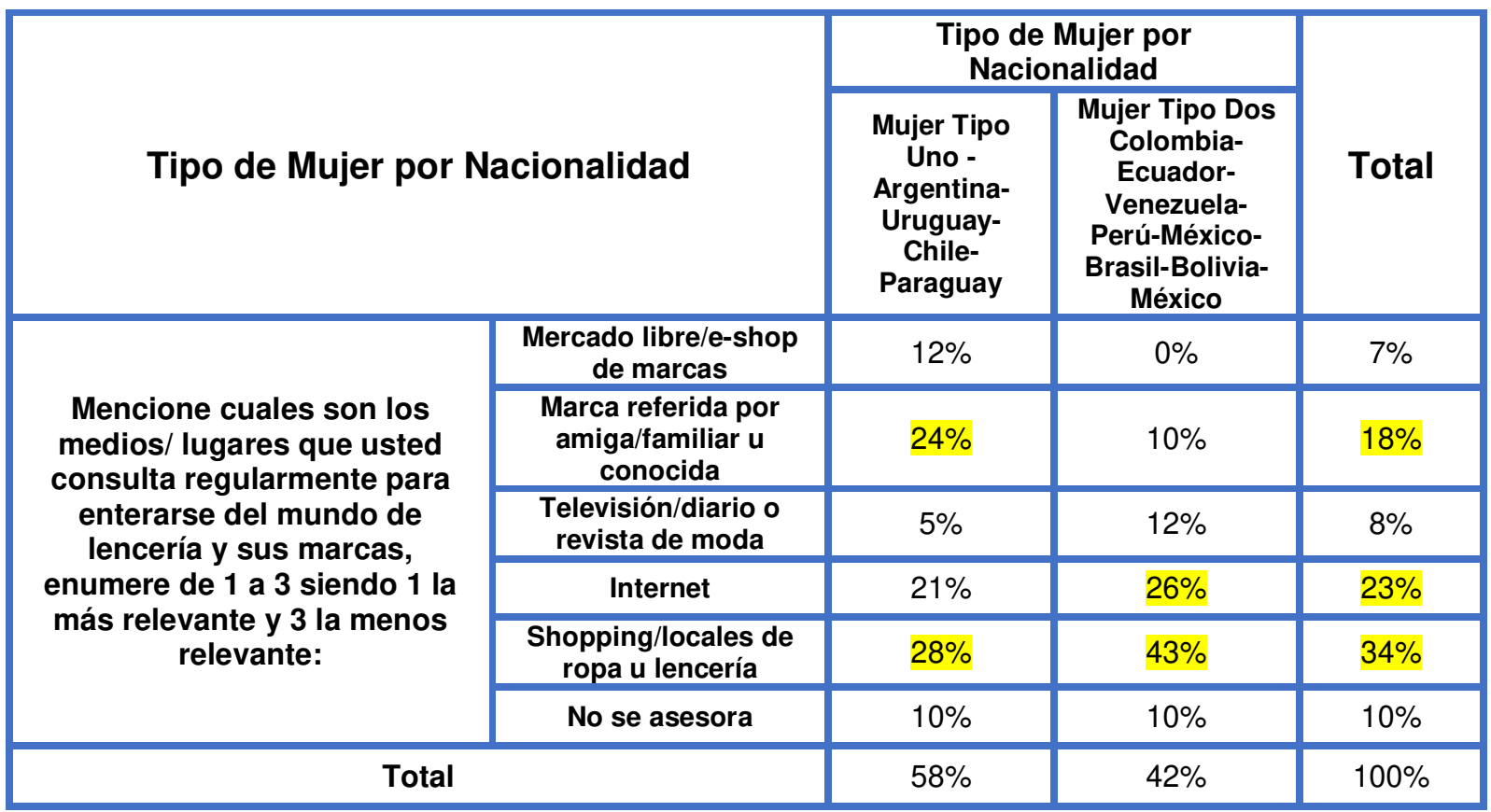

Fuente elaboración propia: Relevamiento encuestas coincidentales, base 100 casos (shi=14,086 y p $<0,015)$

El principal medio de consulta para las latinas son los comercios físicos (retail) con un $34 \%$, seguido por un $23 \%$ el mundo digital (internet), y finalmente por el vigente de boca en boca (referido). Pero al mismo tiempo las argentinas, uruguayas, chilenas y paraguayas prefieren primero consultar el retail, seguido por la marca referida, mientras que el segundo grupo compuesto por las nacionalidades restantes, sigue el orden mencionado inicialmente.

Finalmente nos quedan dos incógnitas claves por abordar, donde prefieren comprar las mujeres analizadas y cuales atributos del producto son más relevantes para ellas al momento de efectuar la compra, para ello se incluyeron dos preguntas incluidas en la encuesta utilizada implementada, mostradas a continuación:

\subsubsection{Lugar de compra: ¿usualmente cuando compra donde lo hace?}

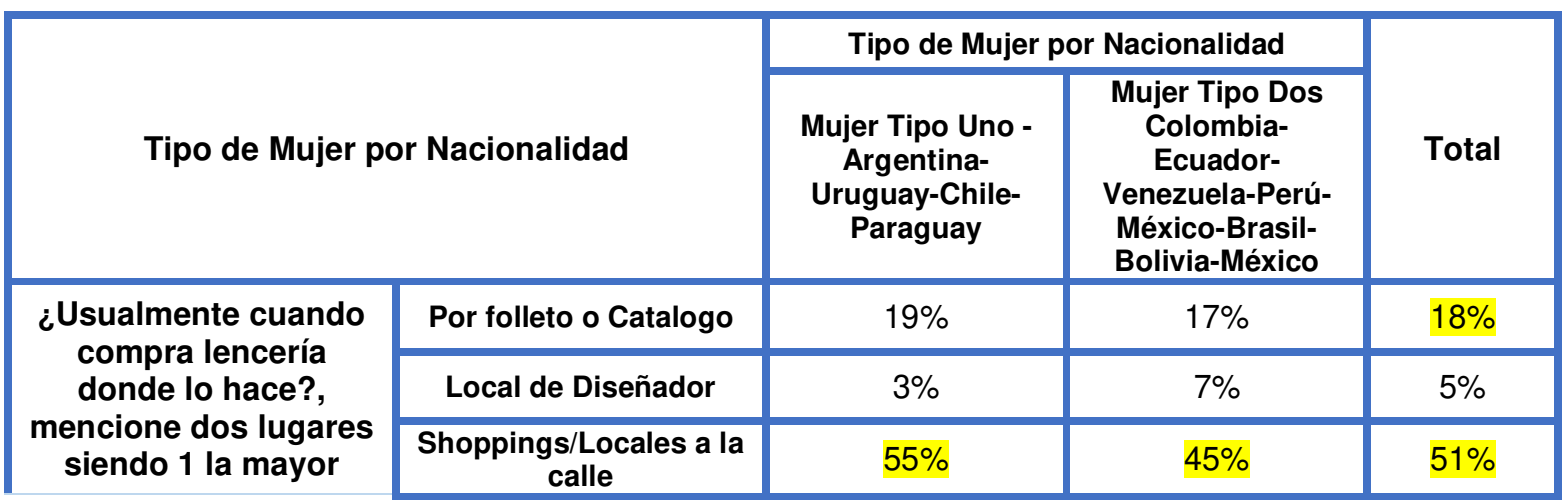




\begin{tabular}{|c|c|c|c|c|}
\hline \multirow{2}{*}{$\begin{array}{c}\text { frecuencia y 2 el de } \\
\text { menor frecuencia. }\end{array}$} & Hipermercados & $7 \%$ & $17 \%$ & $11 \%$ \\
\cline { 2 - 6 } & $\begin{array}{c}\text { Por internet } \\
\text { Mercados } \\
\text { internacionales u Duty } \\
\text { Free }\end{array}$ & $5 \%$ & $0 \%$ & $3 \%$ \\
\hline Total & & $10 \%$ & $14 \%$ & $12 \%$ \\
\hline
\end{tabular}

Fuente elaboración propia: Relevamiento encuestas coincidentales, base 100 casos

Los dos canales de compra más utilizados son con un $51 \%$ de relevancia los Shoppings/Locales a la calle y la venta directa con un $18 \%$, que es una modalidad de venta que tiene mucha relación con el boca a boca, que es una venta referenciada por una consultora de venta, que habla de calidad, precio y marca referida. Sin embargo, en plena era de crecimiento del comercio electrónico, es el canal que menos menciones muestra con un $3 \%$ del total de las opciones referenciadas.

\subsubsection{Atributos del producto: prioridad al momento de compra que tienen para usted al elegir}

\begin{tabular}{|c|c|c|c|c|}
\hline \multirow{2}{*}{\multicolumn{2}{|c|}{$\begin{array}{l}\text { Al momento de elegir una prenda de } \\
\text { lencería para comprar. Ordene del } 1 \text { al } 6 \\
\text { siendo } 1 \text { la más Importante }\end{array}$}} & \multicolumn{2}{|c|}{ Tipo de Mujer por Nacionalidad } & \multirow[b]{2}{*}{ Total } \\
\hline & & $\begin{array}{l}\text { Mujer Tipo Uno - } \\
\text { Argentina- } \\
\text { Uruguay-Chile y }\end{array}$ & $\begin{array}{l}\text { Mujer Tipo Dos } \\
\text { Colombia- } \\
\text { Ecuador- } \\
\text { Venezuela- }\end{array}$ & \\
\hline \multirow{6}{*}{$\begin{array}{l}\text { Determine qué nivel } \\
\text { de prioridad tienen } \\
\text { para usted al } \\
\text { momento de elegir } \\
\text { una prenda de } \\
\text { lencería para } \\
\text { comprar. Ordene del } 1 \\
\text { al } 6 \text { siendo } 1 \text { la más } \\
\text { importante y } 6 \text { la } \\
\text { menos importante. }\end{array}$} & 1) Calidad & $59 \%$ & $55 \%$ & $57 \%$ \\
\hline & 2) Precio & $40 \%$ & $17 \%$ & $30 \%$ \\
\hline & $\begin{array}{l}\text { 3) Variedad de } \\
\text { Diseños }\end{array}$ & $40 \%$ & $14 \%$ & $29 \%$ \\
\hline & $\begin{array}{l}\text { 4) Variedad de } \\
\text { Colores }\end{array}$ & $34 \%$ & $24 \%$ & $30 \%$ \\
\hline & $\begin{array}{l}\text { 5) Packaging } \\
\text { llamativo }\end{array}$ & $34 \%$ & $33 \%$ & $34 \%$ \\
\hline & $\begin{array}{l}\text { 6) Marca } \\
\text { reconocida }\end{array}$ & $31 \%$ & $29 \%$ & $30 \%$ \\
\hline
\end{tabular}

Fuente elaboración propia: Relevamiento encuestas coincidentales, base 100 casos

El análisis del presente cuadro es lineal por atributo relevado, y la incidencia de los porcentajes es individual sobre el total de los demás atributos, por lo tanto, claramente el que mayor impacto genera es la calidad con un $57 \%$ de menciones sobre una base de 100 casos relevados, seguido por el precio, la variedad de diseños, los colores de las prendas, el packaging presentado y por último la marca.

Lo importante es que la variable con mayor peso al momento de elección por las mujeres sin importar el tipo de mujer o nacionalidad es la calidad que pueden presentar las prendas de las distintas marcas al momento de elegir. 


\section{DEFINICIÓN DE LA CONCEPTUALIZACIÓN DE LA MARCA LO QUE DICE EVA}

\subsection{Definición del prototipo y perfil de mujer de interés para la marca}

Como primera medida es necesario tener en cuenta una tarea que regularmente es desarrollada por los gerentes de marketing de cualquier empresa, en la que se identifica cuáles son esas fuerzas externas al marketing que pueden interrumpir o afectar las relaciones exitosas de las empresas con los clientes meta, como lo define Gary Armstrong y Philip Kotler (2012). ${ }^{60}$ Para ello "cuentan con métodos disciplinarios, tales como la investigación de mercados y la inteligencia de marketing para reunir información acerca del entorno de marketing" y a su vez del cliente de interés.

Para tal efecto, y siguiendo dicha premisa se implementaron encuestas coincidentales a distintas mujeres latinas, cuyos resultados fueron esbozados y dados a conocer en el capítulo anterior. Uno de los objetivos de dicho ejercicio era recabar información real que permitiera la construcción del perfil de interés de la clienta para la marca, a través de la identificación de deseos, necesidades e insatisfacciones de las mujeres. Las cuales vislumbran el nicho de interés claro que encaje con la hipótesis planteada inicialmente.

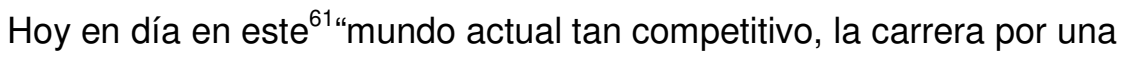
ventaja es en realidad una carrera por la obtención de conocimientos del cliente y del mercado" y "al estudiar cuidadosamente el entorno, seremos capaces de adaptar estrategias para enfrentar nuevos desafíos y aprovechar las oportunidades del mercado" actual.

\footnotetext{
${ }^{60}$ Kotler, P \& Armstrong, G. (2012). Análisis del entorno del Marketing. En Pearson Education (Eds.), Marketing (pp.64-95). Ciudad de México: Pearson Editorial.

${ }^{61}$ Kotler, P \& Armstrong, G. (2012). Información de marketing y compresión de los clientes. En Pearson Education (Eds.), Marketing (pp.98-107). Ciudad de México: Pearson Editorial.
} 
Por consiguiente ¿dónde está ese público de interés? Se encuentra en el mercado

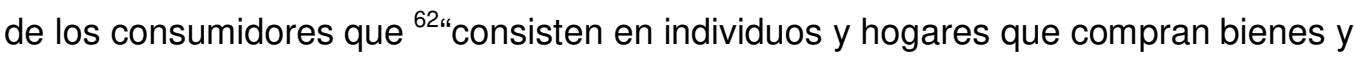
servicios para el consumo personal".

\subsection{Mercado meta de interés para la marca}

Emplearemos el fundamento de marketing meta, el cual permite ${ }^{63 \text { "identificar }}$ segmentos del mercado y seleccionar a uno o más de ellos, y desarrollar productos y programas de marketing a la medida de cada uno de ellos". Consiste en identificar aquellos compradores que muestran interés por los valores que tenemos pensados para la marca, para ello se emplearon las principales variables de segmentación: Geográficas, demográficas y psicográficas.

\subsubsection{Segmentación geográfica}

Los expertos afirman que, al dividir el mercado por zonas geográficas, países etc, le permite operar a las marcas, empresas en dichas zonas. Hablarle a dicho público de forma asertiva, a pesar de que el cliente, pueda encontrarse en otros territorios similares en rasgos definitorios al demarcado inicialmente, ya que nos encontramos en un mundo globalizado, dicho ejercicio genera la conformación de estrategias ajustadas a necesidades, selección de productos, publicidad, promoción y ventas, como lo afirma Gary Armstrong y Philip Kotler (191). ${ }^{64}$

En el primer capítulo para llegar a la conformación de la hipótesis se tuvo en cuenta los rasgos fenotípicos de las mujeres, en cuanto a la estética se refiere. Además, la colonización por zonas, que llevó a la construcción de un pensamiento y costumbres similares entre países. Con la finalidad de saber cuál iba a ser ese público por encuestar dentro del mercado de consumo definido (Latinoamérica). Posteriormente en el segundo capítulo a partir de la tabulación y análisis de las encuestas, resultaron dos grandes grupos de mujeres. La agrupación se hizo por nacionalidades, tomando en cuenta las particularidades de dichos países:

\begin{tabular}{|l|l|l|}
\hline Grupo Uno & Argentina - Uruguay - Chile y Paraguay \\
\hline
\end{tabular}

\footnotetext{
62 Kotler, P \& Armstrong, G. (2012). Análisis del entorno del Marketing. En Pearson Education (Eds.), Marketing (pp.64-95). Ciudad de México: Pearson Editorial.

${ }^{63}$ Kotler, P \& Armstrong, G. (2012). Estrategia del Marketing impulsada por el cliente. En Pearson Education (Eds.), Marketing (pp.190 -198). Ciudad de México: Pearson Editorial.

${ }^{64}$ Kotler, P \& Armstrong, G. (2012). Estrategia del Marketing impulsada por el cliente. En Pearson Education (Eds.), Marketing (pp.190 -198). Ciudad de México: Pearson Editorial.
} 


\section{Grupo Dos Colombia - Venezuela - Perú - Ecuador - México -Brasil y Bolivia}

Fuente elaboración propia: Armado a partir del trabajo de campo realizado a través de las encuestas.

\subsubsection{Segmentación demográfica}

65“Los factores demográficos son las bases más populares para segmentar de clientes. Una razón es que las necesidades de los clientes, sus deseos y su frecuencia de uso suelen variar de acuerdo a las variables demográficas", que son edad, género, ingreso, ocupación, escolaridad, religión y nacionalidad.

Tomando dichos factores y apoyándonos en el análisis de la investigación de campo definieron los siguientes rasgos que debe tener la cliente de la marca:

\begin{tabular}{|c|c|}
\hline Variables & Definición \\
\hline Edad & De 25 a 50 años \\
\hline Escolaridad & $\begin{array}{l}\text { Terciario - Universitario Incompleta - Terciario y Universitario Completo - } \\
\text { Posgrado }\end{array}$ \\
\hline $\begin{array}{l}\text { Nacionalidad - Agrupación } \\
\text { realizada en los dos } \\
\text { grandes grupos. }\end{array}$ & $\begin{array}{l}\text { Argentina, Brasil, Colombia, Venezuela, Chile, Perú, México, Bolivia, } \\
\text { Paraguay, Ecuador y Uruguay. }\end{array}$ \\
\hline Nivel Socioeconómico & Ingreso Superior o igual a 1.000 USD mensuales aproximadamente \\
\hline Generación & $\begin{array}{l}\text { Se apunta a las personas nacidas a partir de 1965, que abarca la } \\
\text { Generación X (nacidos 1965) y la del milenio (nacidos } 1976 \text { al 2000), ya } \\
\text { que son los que más pueden estar en contacto con tecnología digital } \\
\text { (celulares inteligentes, redes sociales, Tablet y computadoras) (73) }\end{array}$ \\
\hline Ocupación & $\begin{array}{l}\text { Profesional y Técnica; gerentes y empresarios; funcionarios, oficinistas, } \\
\text { supervisores; estudiantes y amas de casa. }\end{array}$ \\
\hline Genero & Femenino incluidos transgéneros \\
\hline Religión & $\begin{array}{l}\text { Católica - Judía - Musulmana - Hinduismo - Budismo - Personas sin } \\
\text { credo definido. }\end{array}$ \\
\hline \multicolumn{2}{|c|}{ Fuente elaboración propia: Armado a partir del trabajo de campo realizado a través de las } \\
\hline $\begin{array}{l}{ }^{65} \text { Kotler, P \& Armstrong, G. (201 } \\
\text { (Eds.), Marketing (pp.190 -198). } \\
{ }^{66} \text { Kotler, P \& Armstrong, G. (201 } \\
\text { Marketing (pp.64-95). Ciudad de }\end{array}$ & $\begin{array}{l}\text { Estrategia del Marketing impulsada por el cliente. En Pearson Education } \\
\text { udad de México: Pearson Editorial. } \\
\text { Análisis del entorno del Marketing. En Pearson Education (Eds.), } \\
\text { léxico: Pearson Editorial. }\end{array}$ \\
\hline
\end{tabular}




\subsubsection{Segmentación psicográficas}

Esta segmentación permite dividir a los ${ }^{67}$ "consumidores en diferentes grupos grupos según la clase social, el estilo de vida o las características de personalidad". Como se hizo mención en una primera instancia, se armaron dos grandes grupos denominados tipo de mujer, donde se agrupó a las mujeres por países según sus similitudes generales, el cual se complementó con la información recabada en el campo, a través de la investigación de mercados, de donde se extrajeron los rasgos de la personalidad. Es importante y primordial para el éxito de la marca lo mencionado por los autores citados, ya que a pesar de que todas las encuestadas pertenecen a una misma región muestran diferentes rasgos, y no tuvieron reparo en dejarlo a la vista, en cuanto a gustos tan sencillos como preferencias de colores, tipo de prendas que suelen usar, que enmarcan las pautas de comportamiento por las cuales suelen regirse, y sería un error desechar sin previo análisis.

\begin{tabular}{|l|l|l|l|}
\hline Grupos Femeninos & Estilo de Vida & Personalidad & Clase Social \\
\hline $\begin{array}{l}\text { Tipo Uno - Argentina, } \\
\text { Chile, Uruguay y } \\
\text { Paraguay }\end{array}$ & $\begin{array}{l}\text { Vanidad equilibrada - } \\
\text { discreta - exitosas - } \\
\text { deseo por el confort }\end{array}$ & $\begin{array}{l}\text { Inquieta/curiosa - } \\
\text { reservada pero no pacata } \\
\text { - ambiciosa - segura - } \\
\text { inteligente - buen gusto - } \\
\text { autentica }\end{array}$ & $\begin{array}{l}\text { ABC1 - Clase Alta } \\
\text { C3 - Clase Media Alta } \\
\text { C2 - Clase Media }\end{array}$ \\
\hline $\begin{array}{l}\text { Tipo Dos - Colombia, } \\
\text { Venezuela, Perú, } \\
\begin{array}{l}\text { México, Brasil, Bolivia } \\
\text { y Ecuador }\end{array}\end{array}$ & $\begin{array}{l}\text { Vanidad y Belleza } \\
\text { aumentada - } \\
\text { Luchadoras - deseo por } \\
\text { el confort }\end{array}$ & $\begin{array}{l}\text { Sociable - Coqueta - } \\
\text { Histriónica - ambiciosa - } \\
\text { segura -inteligente - } \\
\text { buen gusto - auténtica }\end{array}$ & $\begin{array}{l}\text { ABC1 - Clase Alta } \\
\text { C3 - Clase Media Alta } \\
\text { C2 - Clase Media }\end{array}$ \\
\hline
\end{tabular}

Fuente elaboración propia: Armado a partir del trabajo de campo realizado a través de las encuestas.

\subsection{Diseño y desarrollo del perfil de la marca}

La creación, desarrollo y diseño del perfil de la marca es el armado de la personalidad, los valores, la propuesta de valor, la impronta que va a expresar la marca "Lo que dice Eva" para los clientes y el mercado. La finalidad es crear una marca que esté alineada con los deseos que presentan las mujeres segmentadas, llamadas tipo uno

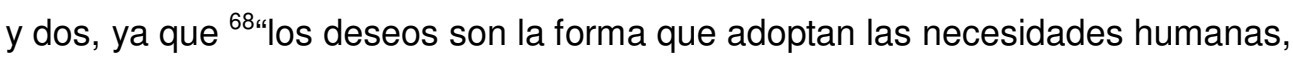
moldeadas por la cultura y la personalidad individual".

\footnotetext{
${ }^{67}$ Kotler, P \& Armstrong, G. (2012). Estrategia del Marketing impulsada por el cliente. En Pearson Education (Eds.), Marketing (pp.190 -198). Ciudad de México: Pearson Editorial.

${ }^{68}$ Kotler, P \& Armstrong, G. (2012). Qué es el Marketing. En Pearson Education (Eds.), Marketing (pp.4-13). Ciudad de México: Pearson Editorial.
} 
Al mismo tiempo es importante contextualizar el significado de lo que son las necesidades humanas que ${ }^{69}$ "son estados de carencia percibida, e incluyen las necesidades físicas básicas de alimento, ropa, calidez y seguridad; las necesidades sociales de pertenencia y afecto; y las necesidades individuales de conocimiento y expresión personal", con la finalidad de aclararle el camino al éxito, para la naciente marca.

Ahora bien, tomando los resultados del trabajo de campo realizado, podemos comenzar a darle marco de creación al perfil de marca. Lo interesante es que el marco que se va a mostrar a continuación, guarda relación y reconfirma la hipótesis que se planteó inicialmente para el presente trabajo académico. Para ello se traerá a colación las respuestas de las mujeres encuestadas de una pregunta y de una afirmación propuesta a validación: ¿las marcas de lencería femenina son excluyentes con mujeres de su tipo? - afirmación: Las marcas de lencería proponen un tipo de mujer perfecta (piernas alargadas, estilizadas, jóvenes) que hace sentir frustración a la mayoría de las mujeres. El $48 \%$ de las mujeres respondió estar muy de acuerdo y el $27 \%$ estar de acuerdo, tabla de resultados mostrada en la página 33 del presente trabajo. Dicho esto, el perfil de la marca Lo que dice Eva debe estar enmarcada por el entendimiento principalmente de dos necesidades: las individuales y las sociales, que se conjugan y traducen la necesidad de la mujer latina por expresarse a nivel corporal, sentirse aceptada y al mismo tiempo sentirse reconocida por el círculo social en el que se desenvuelve.

\subsubsection{Raíces de la marca}

70“Una marca es un nombre, término, letrero, símbolo o diseño, o la combinación de estos elementos, que identifica al fabricante o vendedor de un producto o servicio". Lo interesante es que cada marca sea conocida, distinguida por sus compradores por beneficios que les otorgan, ya sea por sus productos 0 por el valor de la propuesta que genera conexión con sus clientes a nivel emocional. Estos factores van a ser las fortalezas de la marca, es el material con el que cuentan los mercadólogos para hacer conocida la marca. La marca es el principal activo que tiene una empresa como lo definió un antiguo director de

\footnotetext{
${ }^{69}$ Kotler, P \& Armstrong, G. (2012). Qué es el Marketing. En Pearson Education (Eds.), Marketing (pp.4-13). Ciudad de México: Pearson Editorial.

${ }^{70}$ Kotler, P \& Armstrong, G. (2012). Productos, Servicios y Marcas. En Pearson Education (Eds.), Marketing (pp.222-255). Ciudad de México: Pearson Editorial.
} 
McDonald's que declaro ${ }^{71}$ "si cada bien que poseemos, cada edificio y cada pieza de equipo se destruyeran en un terrible desastre natural, seríamos capaces de pedir prestado todo el dinero para reemplazarlo con rapidez debido al valor de nuestra marca...La marca es más valiosa que la totalidad de estos activos".

En consecuencia, a continuación, se van a enunciar, aquellos intangibles que van a dar sentido, y van a ser los pilares de la marca en cuestión para que pueda hacerse conocida dentro del segmento de mujeres predefinido anteriormente, en este caso van a estar asociados al producto y al valor que permita generar un vínculo emocional con el cliente:

- Marca que invita a romper con el pensamiento de belleza única y perfecta.

- Marca que invita a la mujer latina a reconocerse bella e interesante.

\subsubsection{Valor de la marca}

Este es otro tópico central a tener en cuenta al momento de crear una marca, ya que se puede decir que el valor de la marca ${ }^{72 ، e s ~ u n a ~ m e d i d a ~ d e ~ l a ~ c a p a c i d a d ~ q u e ~ t i e n e ~}$ la marca para obtener la preferencia y lealtad del cliente". O sea, es la razón por la cual los clientes elijen el producto de una marca específica, frente a otra con el mismo producto o un genérico exactamente igual, lo cual significa mayores ventas para la marca.

En este momento podríamos decir que la marca a crear Lo que dice Eva carece de valor alguno, otros dirían que su valor es cero, y que no debería mencionarse en esta instancia del trabajo, siendo completamente cierta dicha aseveración. La realidad es que tiene un valor inconmensurable, en el que todo emprendedor tiene que hacer foco desde el punto de partida, justamente porque debe cuidar los detalles para que el potencial de la marca sea cuantificable en un futuro.

La marca lo que dice Eva va a tener éxito porque apunta a generar conexiones con sus clientes, a potencializar la política de comunicación, a cuidar la línea de producto, y a destacar el valor agregado descrito en el punto anterior de las raíces de la marca.

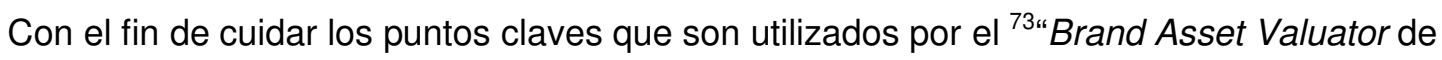
la agencia de publicidad Young \& Rubicam. Que mide la fuerza de una marca a lo largo de cuatro dimensiones de la percepción de los consumidores: diferenciación (Lo que

\footnotetext{
${ }^{71}$ Kotler, P \& Armstrong, G. (2012). Productos, Servicios y Marcas. En Pearson Education (Eds.), Marketing (pp.222-255). Ciudad de México: Pearson Editorial.

72 Kotler, P \& Armstrong, G. (2012). Productos, Servicios y Marcas. En Pearson Education (Eds.), Marketing (pp.222-255). Ciudad de México: Pearson Editorial.

Kotler, P \& Armstrong, G. (2012). Productos, Servicios y Marcas. En Pearson Education (Eds.), Marketing (pp.222-255). Ciudad de México: Pearson Editorial.
} 
hace que la marca se destaque), relevancia (si los consumidores piensan que cubre sus necesidades), conocimiento (cuánto saben los consumidores acerca de la marca) y estima (la consideración y el respeto que tienen los consumidores por la marca)".

\subsubsection{Atributos y beneficios de los productos de la marca}

Es de suma importancia y de vital relevancia tener en cuenta el significado del concepto ventaja competitiva, para que sea más fácil encontrar aquellos beneficios, y atributos que la marca ofrecerá a sus clientas. Con el fin de lograr que las clientas prefieran a la marca naciente por encima de otras marcas, es por ello que empezaremos por definir el concepto: Son aquellos rasgos, valores y características intrínsecas o extrínsecas del producto ofertado, que permite a una

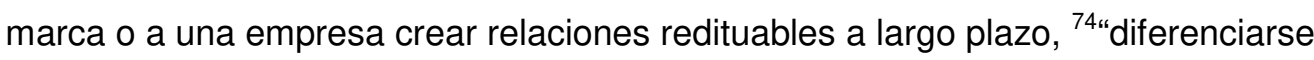
y posicionarse como proveedora de valor superior para el cliente".

Para el presente caso de creación de la marca lo que dice Eva, se tomará como base lo que mencionaron las mujeres encuestadas, para definir los atributos y beneficios que debe tener la marca y sus productos, ya que elementalmente

${ }^{75}$ “la ropa interior tiene tres usos básicos. El primero y elemental es el que explicita su nombre: es ropa interior y se usa debajo de la exterior, otras veces se elige para que se vea debajo de la ropa, ya sea porque usamos prendas transparentes o porque las pendas dejan ver un bretel o un elástico. Finalmente, está la que usamos para seducir cuando estamos dispuestas a quitarnos la ropa".

Ahora bien, es momento de traer a colación aquellos atributos que se recabaron en el trabajo de campo:

\begin{tabular}{|c|c|c|c|c|}
\hline Preferencia & Atributo & $\begin{array}{c}\text { Mujer Tipo Uno- } \\
\text { Argentina-Uruguay-Chile } \\
\text { y Paraguay }\end{array}$ & $\begin{array}{c}\text { Mujer Tipo Dos Colombia- } \\
\text { Ecuador-Venezuela-Perú-Brasil- } \\
\text { Bolivia y México }\end{array}$ & Total \\
\hline Primero & Calidad & $33 \%$ & $48 \%$ & $39 \%$ \\
\hline Segundo & Confort & $19 \%$ & $31 \%$ & $24 \%$ \\
\hline Tercero & Diseño & $19 \%$ & $17 \%$ & $18 \%$ \\
\hline Cuarto & Buen Precio & $29 \%$ & $10 \%$ & $21 \%$ \\
\hline Quinto & Sensualidad & $22 \%$ & $14 \%$ & $19 \%$ \\
\hline
\end{tabular}

\footnotetext{
${ }^{74}$ Kotler, P \& Armstrong, G.(2012).Marketing Real. En Pearson Education (Eds.), Marketing (pp.209-2017). Ciudad de México: Pearson Editorial.

${ }^{75}$ Aubele, C. (2010). La Ropa Interior. En Aguilar (Eds.), Secretos del Vestidor (pp. 114-120). Buenos Aires: Editorial Aguilar, Altea, Taurus, Alfaguara, S.A.
} 


\subsubsection{Conceptualización y definición del atributo central de la marca}

Después de haber expuesto aquellos atributos que tendrán los productos de la de la marca, relacionados con el deseo/necesidades de las mujeres latinas, según lo que lo que esperan de un producto de lencería. Se ha decidido aclarar la política que debe adoptar la marca en cuanto al manejo de los atributos intrínsecos de los productos que quiere comercializar. Ya que ${ }^{76}$ "los consumidores perciben los productos como conjuntos complejos de beneficios que satisfacen sus necesidades. Al desarrollar productos, los mercadólogos primero deben identificar el valor fundamental que los consumidores buscan en el producto. Luego, deben diseñar el producto real, y encontrar formas para aumentarlo y crear este valor y la experiencia más satisfactoria para el cliente".

En consecuencia la marca debe situarse en el eslabón de "producto aumentado" siguiendo la definición hecha por Gary Armstrong y Philip Kotler en su libro Marketing en la pág. 226. Es de vital importancia ya que los atributos que promulgan las marcas generan un concepto en el mercado, que repiten los clientes a diario y construyen una imagen de la marca y sus productos.

77“Una compañía no puede desarrollar una imagen consistente en la mente del público de la noche a la mañana, utilizando sólo algunos anuncios. Si Ritz-Carlton significa calidad, esta imagen debe estar sustentada por todo lo que la empresa dice y hace".

En consecuencia muchos mercadólogos se pronuncian sobre ¿cuantas diferencias deben promover las empresas?, en cuanto a los atributos de su marca: 78،cada marca debe elegir un atributo y proclamar (número uno) en ese atributo, otros piensan que las empresas deben promocionarse con base en el mayor atributo diferenciador". Y finalmente hay otros que piensan que si se promueve más de un atributo, ${ }^{79}$ “el desafío consiste en convencerlos de que una marca puede ser todo. Sin embargo, conforme las compañías incrementan la cantidad de operaciones sobre sus marcas, se arriesgan a la desconfianza y a la pérdida de posicionamiento claro".

La marca no será promulgada ni identificada de forma masiva con los atributos físicos que van a tener los productos de la marca: Calidad, confort, diseño y precio. Ya

\footnotetext{
${ }^{76}$ Kotler, P \& Armstrong, G.(2012). Productos, Servicios y Marcas. Creación de Valor para el Cliente. En Pearson Education (Eds.), Marketing (pp.225-227). Ciudad de México: Pearson Editorial.

${ }_{77}$ Kotler, P \& Armstrong, G. (2012). Selección de una Estrategia de Diferenciación y Posicionamiento. En Pearson Education (Eds.), Marketing (pp.208-215). Ciudad de México: Pearson Editorial.

${ }^{78}$ Kotler, P \& Armstrong, G. (2012). Selección de una Estrategia de Diferenciación y Posicionamiento. En

Pearson Education (Eds.), Marketing (pp.208-215). Ciudad de México: Pearson Editorial.

${ }^{79}$ Kotler, P \& Armstrong, G. (2012). Selección de una Estrategia de Diferenciación y Posicionamiento. En Pearson Education (Eds.), Marketing (pp.208-215). Ciudad de México: Pearson Editorial.
} 
que el atributo que liderará el posicionamiento de la marca será complementario a la raíz de la marca, definido en la página 41 anteriormente: Marca para la mujer

Latina, que reconoce su belleza, sus necesidades y está hecha para ella, porque es una mujer importante.

\subsubsection{Misión}

Cuando hablamos de misión de marca para empresas de lencería femenina, automáticamente la mujer latina tiende a pensar en orden de importancia en marcas como: Victoria's Secret, Leonisa y Cocot, según lo contestado por las encuestadas en el trabajo de campo realizado para el presente trabajo, (resultados pág. 29-30capítulo II). ${ }^{80 " D e ~ h e c h o, ~ l a ~ m i s i o ́ n ~ d e ~ m a r c a ~ n o ~}$ depende de la popularidad, sino de la medida en que los públicos perciben que "detrás" de una marca hay un colectivo de personas ilusionadas por llevar a cabo una misión que vale la pena".

Este punto es muy importante para una naciente marca, ya que ${ }^{81 \text { “La }}$ misión de marca es uno de esos conceptos poderosos que va a generar una gran influencia en la forma en que se desarrollará el marketing en las próximas décadas", Lo importante es que todos los integrantes de la empresa, desde los dueños hasta el empleado con la menor jerarquía, y su cadena de valor (intermediarios, proveedores, etc) deben conocer, compartir y trabajar por dicho objetivo, porque es lo que la empresa/marca le aporta al mundo, principalmente a sus clientes.

En ese caso se construirá una misión con aquello que la marca desea trasmitir a sus clientes principalmente, donde se mencione el valor principal que permita contribuir a la conexión con la marca:

El objetivo principal de la marca Lo que dice Eva, es la comercialización de lencería femenina de calidad y diseño acorde, para la mujer latina. A partir de la conexión de la marca con el pensamiento, las necesidades, deseos y anhelos que la atraviesan.

\footnotetext{
${ }^{80}$ Rey,C.(2014). La Misión de la Marca. Voces para entendernos. Barcelona, España: Sumando Historias. Recuperado 9 de julio del 2018 de: http://www.sumandohistorias.com/voces/para-entendernos/la-mision-dela-marcal

${ }^{81}$ Rey,C.(2014). La Misión de la Marca. Voces para entendernos. Barcelona, España: Sumando Historias. Recuperado 9 de julio del 2018 de: http://www.sumandohistorias.com/voces/para-entendernos/la-mision-dela-marcal
} 


\subsubsection{Visión}

Este es uno de los cimientos más importante para cualquier marca, ya que

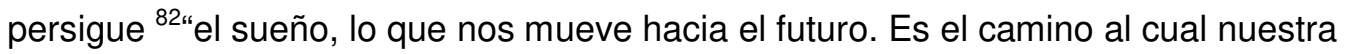
nuestra marca se dirige en el largo plazo y sirve de rumbo para orientar todos nuestros nuestros esfuerzos y decisiones estratégicas. Se la suele denominar como una declaración de aspiraciones que tenemos, es la imagen de cómo deseamos ser más más adelante. Es un lindo ejercicio, tomar un papel, un lápiz, y dibujarnos como nos nos vemos hoy, y como quisiéramos vernos en 10 años".

Ahora bien, en consecuencia mencionaremos cual sería la visión que tendría que perseguir la marca: En los próximos años ser la marca mejor posicionada en el colectivo femenino latino, como la mejor marca de lencería, Cómo la marca que entiende a la mujer actual, sus necesidades y la que se conecta con sus emociones y empatiza con ellas.

\subsection{Diagramación y diseño del producto final (línea/s de colección)}

Lo primero es contextualizar ¿Qué es una línea de productos?, se encontró la siguiente definición: ${ }^{83}$ "es un grupo de productos que están estrechamente relacionados porque funcionan de manera similar, se venden a los mismos grupos de clientes, se comercializan a través de los mismos tipos de punto de venta o quedan dentro de cierto rango de precios".

En consecuencia, dicha definición delimita el camino que la marca debe seguir, en cuanto a la cantidad de artículos, líneas a construir, tipo de productos que va a ofertar, y a quien se los venderá. Por ende se recuerda el perfil de mujer que se describió en el capítulo I en las páginas (09-11) inicialmente. La marca apunta a un grupo de clientes específicos (mujeres latinas), quienes a su vez se subdividen en dos grandes grupos de mujeres, que comparten rasgos fenotípicos, comportamentales y socioculturales entre ellas. Por consiguiente cada grupo de mujeres debe tener una línea de productos que se amolde a ellas, en cuanto al diseño de las prendas principalmente, y a el tipo de prendas que se le ofertarán.

Después de haber entendido que se generarán dos líneas de productos, lo segundo es abordar las prendas que la marca ofertará, según los tipos de mujer.

\footnotetext{
${ }^{82}$ Carreño,L.(2018). "Cómo definir Misión, Visión y Valores en tu Marca". Smilemkt. Buenos Aires, Argentina. Recuperado el 10 de agosto del 2018 de: https://smilemkt.com.ar/definir-mision-vision-valores/

${ }^{83}$ Kotler, P \& Armstrong, G. (2012). Productos, Servicios y Marcas. Decisiones de Línea de Productos. En Pearson Education (Eds.), Marketing (pp.234-236). Ciudad de México: Pearson Editorial.
} 
Tomando las encuestas realizadas como base, se pudo inferir el tipo de prendas que debe tener cada línea: Lencería de uso diario/cómoda, de diseño/Sensual y finalmente de descanso/pijamas, según el relevamiento coincidental que se realizó y se mencionó en el capítulo II del presente trabajo:

Tabla - Medición por tipo de Lencería

\begin{tabular}{|c|c|c|c|c|}
\hline Preferencia & Tipo de Lencería & $\begin{array}{c}\text { Mujer Tipo Uno - } \\
\text { Argentina-Uruguay- } \\
\text { Chile- Paraguay }\end{array}$ & $\begin{array}{c}\text { Mujer Tipo Dos Colombia- } \\
\text { Ecuador-Venezuela-Perú- } \\
\text { Brasil-Bolivia-México }\end{array}$ & $\begin{array}{l}\text { Total } \\
\text { Primera }\end{array}$ \\
\hline Segunda & Uso diario, cómoda & $78 \%$ & $88 \%$ & $82 \%$ \\
\hline Tercera & Depual de diseño & $24 \%$ & $52 \%$ & $36 \%$ \\
\hline Cuarta & Pijamas, ropa de descanso & $28 \%$ & $36 \%$ & $31 \%$ \\
\hline Quinta & Reductora, para modelar el & $33 \%$ & $31 \%$ & $32 \%$ \\
\hline
\end{tabular}

Por último queda definir los parámetros inherentes al diseño de las prendas, que maneja los factores relacionados a la textura, colores, y cortes de las prendas, que se ven en el momento de la creación en sí de las colecciones, y no representa mayor relevancia para el presente caso de estudio, ya que ellos se rigen por las tendencias de la moda. Lo que sí podemos definir es el manejo que se le darán a los atributos de la marca como: la calidad, el diseño, el confort y el precio para las líneas. Los cuales generan un beneficio adicional para el cliente.

El nivel que debe manejar la marca en cuanto a la calidad, diseño y el confort, debe ser de un nivel superior frente a otras marcas, con el fin que el cliente vea maximizadas sus necesidades/expectativas con respecto a la variable precio (precio competitivo), dicha ecuación le beneficia al cliente y a la marca, como vimos la cliente se siente satisfecha, identificada, y la marca genera mayores volúmenes de venta, por ende mayores ingresos y utilidad al final de cada ejercicio.

\subsection{Creación de distintivos de la marca (logo - etiqueta -empaque)}

\subsubsection{Logo de la marca}

La creación del logo o isologo para cualquier marca, es una tarea no menor. Para dicho momento creativo y saber ¿cómo hacerlo?, es indispensable tener presente lo que la marca desea comunicar y la reacción que desea generar en el público meta al cual se dirige. Para ello mencionaremos algunas definiciones 
de marca, con el fin de refrescar lo que pretende la marca del presente estudio: ${ }^{84 " l a}$ marca debe distinguirse o los consumidores no tendrán razones para elegirla sobre las demás", ${ }^{85}$ “las marcas más fuertes se posicionan más allá de los atributos o los beneficios: lo hacen con base en creencias y valores sólidos. Estas marcas conllevan una

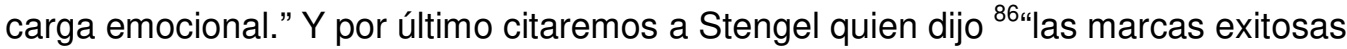
involucran a los clientes a un nivel emocional profundo, el marketing inspira vida, y la vida inspira marketing".

Ahora bien hemos ratificado una vez más el tipo de marca que se quiere crear, como se hizo en la pág. 41 en la parte de Raíces de la marca, fundamental para la creación de la identidad visual. Se refresca el concepto para que llegado el momento el área de diseño gráfico pueda realizar un trabajo asertivo correcto, teniendo claridad a lo que apunta la marca Lo que dice Eva para el caso de estudio.

En consecuencia, vamos a continuar con el análisis del nombre que se eligió para la marca, ya que éste también puede hacer parte del isologo, y además según autores de marketing como: Kotler y Armstrong expresan que un "buen nombre contribuye con el éxito del producto". El nombre "Lo que dice Eva", cumple con aspectos que pensaríamos que van a llevar a que la marca sea un caso de éxito, a continuación describiremos algunos aspectos:

\begin{tabular}{|c|c|}
\hline Aspectos & Definición en la Marca de estudio \\
\hline $\begin{array}{c}\text { Debe Sugerir algo acerca de los beneficios } \\
\text { y cualidades del Producto }\end{array}$ & $\begin{array}{c}\text { A través del nombre femenino busca generar una conexión } \\
\text { emocional con la mujer latina, ya que Eva tiene las mismas } \\
\text { necesidades que las demás mujeres. }\end{array}$ \\
\hline $\begin{array}{c}\text { Debe ser fácil de pronunciar, reconocer y } \\
\text { recordar }\end{array}$ & Cumple con el aspecto de forma satisfactoria \\
\hline Tiene que ser Distintivo & Es innovador y Distintivo \\
\hline $\begin{array}{c}\text { Tiene que poderse Registrar y Protegerse } \\
\text { Legalmente }\end{array}$ & No es relevante en este punto, es un ejercicio académico. \\
\hline
\end{tabular}

Finalmente teniendo en claro qué característica debe atravesar el armado del logo, solo faltaría pasarle la información a un diseñador gráfico para que arme la pieza visual.

\subsubsection{Etiqueta de la marca}

\footnotetext{
${ }^{84}$ Kotler, P \& Armstrong, G.(2012). Estrategia de Asignación de Marcas: Creación de Marcas Fuertes. En Pearson Education (Eds.), Marketing (pp.243-246). Ciudad de México: Pearson Editorial.

${ }^{85}$ Kotler, P \& Armstrong, G.(2012). Estrategia de Asignación de Marcas: Creación de Marcas Fuertes. En Pearson Education (Eds.), Marketing (pp.243-246). Ciudad de México: Pearson Editorial.

${ }^{86}$ Kotler, P \& Armstrong, G.(2012). Estrategia de Asignación de Marcas: Creación de Marcas Fuertes. En Pearson Education (Eds.), Marketing (pp.243-246). Ciudad de México: Pearson Editorial.
} 
Las etiquetas de cualquier producto permiten identificar la marca a la que pertenecen, es la función máxima que tienen que cumplir, además deben informar

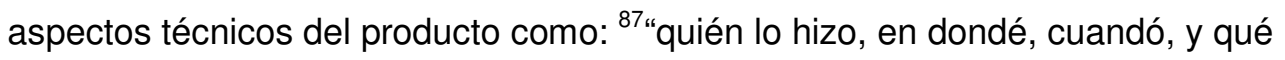
cómo se usa y las medidas de seguridad. Finalmente la etiqueta podría servir para promocionar la marca, apoyar su posicionamiento y conectarla con los clientes".

Ahora bien, las etiquetas de la marca van a contener, la información técnica de los productos. Es importante y debe estar correctamente informada en la misma, por dos razones: la primera es generar confianza y evitar conflictos con las clientas por desinformación en cuanto al uso de las prendas o el tipo de tela con las que fueron confeccionadas. La segunda, y es aquí donde la marca decide ampliar el foco, se refiere al posicionamiento que la marca pueda generar en las clientas a través de las etiquetas. Es una tarea inherente al diseño gráfico, y es

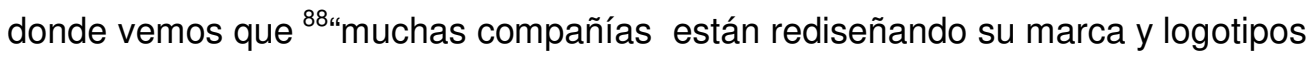
de la empresa para lograr que sean más accesibles, modernos y atractivos. La imagen rectangular y monocromática es obsoleta, y las fuentes suaves, con muchos colores e imágenes naturales, están de moda". En consecuencia como la marca desea mostrarse como una empresa innovadora, y que está a la vanguardia de la moda, es claro a donde debe apuntar en cuanto al diseño de la etiqueta.

\subsubsection{Packaching de la marca}

En esta parte del trabajo nos basaremos en dos características esenciales que los empaques de cualquier producto deben tener, según la experiencia de muchas empresas. Estas dos particularidades son las que tendrán los empaques de los productos de la marca naciente. En una primera instancia los mencionaremos, y seguido a esto se sustentará porque motivo se eligieron estas dos características que son: la Innovación y la practicidad.

Con la Innovación la marca busca llamar la atención, para aumentar la probabilidad de compra entre las consumidoras, y además demostrar el atributo calidad del producto. ${ }^{89 ، .}$. Los empaques ahora deben desempeñar tareas de ventas; describir el producto, venderlo y llamar la atención”. El uso de empaques

\footnotetext{
${ }^{87}$ Kotler, P \& Armstrong, G.(2012).Productos, Servicios y marcas. Creación de valor para el Cliente. En Pearson Education (Eds.), Marketing (pp.233). Ciudad de México: Pearson Editorial.

${ }^{88}$ Kotler, P \& Armstrong, G.(2012).Productos, Servicios y marcas. Creación de valor para el Cliente. En Pearson Education (Eds.), Marketing (pp.233). Ciudad de México: Pearson Editorial.

${ }^{89}$ Kotler, P \& Armstrong, G.(2012). Diseño de una estrategia y una mezcla de marketing impulsada por los consumidores. En Pearson Education (Eds.), Marketing (pp.232). Ciudad de México: Pearson Editorial.
} 
innovadores puede proporcionarle a una compañía una ventaja sobre los competidores e incrementar sus ventas".

Ahora hablaremos del por qué del envoltorio de los productos de Lo que dice Eva dice Eva deben ser prácticos para las clientas, sencillamente porque ${ }^{90 " l o s ~ e m p a q u e s ~ m a l ~}$ empaques mal diseñados provocan dolores de cabeza a los consumidores y hacen perder ventas a la empresa".

En conclusión lo que entiende la marca es que el ${ }^{91}$ "empaque podría ser la última oportunidad de los comerciantes de influir en los compradores".

\footnotetext{
${ }^{90}$ Kotler, P \& Armstrong, G.(2012). Diseño de una estrategia y una mezcla de marketing impulsada por los consumidores. En Pearson Education (Eds.), Marketing (pp.232). Ciudad de México: Pearson Editorial.

${ }^{91}$ Kotler, P \& Armstrong, G.(2012). Diseño de una estrategia y una mezcla de marketing impulsada por los consumidores. En Pearson Education (Eds.), Marketing (pp.232). Ciudad de México: Pearson Editorial.
} 


\section{DESARROLLO DE LA ESTRATEGIA COMERCIAL, DE POSICIONAMIENTO DE LA MARCA LO QUE DICE EVA}

\subsection{Estrategia de posicionamiento de la marca}

En el presente capítulo se tratará de reunir y presentar todas aquellas variables que son necesarias para que una marca de lencería femenina pueda posicionarse en la mente de la consumidora a la cual desea dirigirse. El objetivo esencial de dicha estrategia es poder comercializar los productos que ofrece $y$ además establecerse en la mente del consumidor de forma positiva/exitosa para que recuerde la marca y sus productos. Persigue un único resultado, que finalmente la clienta vuelva a elegir los productos de la marca y realice la acción de comprar tantas veces como sea posible.

92“'Los consumidores están sobrecargados de información sobre productos y servicios. No pueden volver a evaluar los productos cada vez que toman una decisión de compra. Para simplificar el proceso de compra, los consumidores organizan los productos, los servicios y las empresas en categorías, y los "posicionan" en su mente. La posición de un producto es el complejo conjunto de percepciones, impresiones y sentimientos que los consumidores tienen respecto del producto, en comparación con los productos de la competencia".

A continuación vamos a definir cuáles serían aquellos atributos que la marca debe adoptar en su estrategia de posicionamiento, para ello lo que haremos es seguir los tres pasos que proponen Kotler y Armstrong en el libro Marketing en la página 208 a lo que denominan Tarea de diferenciación y posicionamiento:

\subsubsection{Identificación de ventajas competitivas}

En esta primera etapa, es donde las marcas deben analizar y detectar aquellas Ventajas que pueden ofrecer a sus clientes, en síntesis es lo que se denomina en cualquier proceso de investigación como etapa exploratoria. Para el caso es muy

\footnotetext{
92 Kotler, P \& Armstrong, G.(2012). Estrategia de Marketing Impulsada por el Cliente: creación de valor para los clientes Meta. En Pearson Education (Eds.), Marketing (pp.207-215). Ciudad de México: Pearson Editorial.
} 
importante ya que es esencial ${ }^{93 ، " p a r a ~ e s t a b l e c e r ~ r e l a c i o n e s ~ r e d i t u a b l e s ~ c o n ~ l o s ~ c l i e n t e s ~}$ meta, los mercadólogos deben entender las necesidades de los consumidores mejor que los competidores y entregarles mayor valor. Dependiendo del grado en que la empresa pueda diferenciarse y posicionarse como proveedora de valor superior para el cliente, gana una ventaja competitiva".

En consecuencia para poder establecer las ventajas competitivas que va a tener la marca de lencería del presente caso de estudio, se tomará de apoyo el relevamiento realizado a mujeres latinas, mostrado en el capítulo II de la pag. 24 a la 36, Utilizándolo como base de argumentación documental, ya que al ser un emprendimiento que nace de cero carece de información sobre la experiencia del cliente con el producto y con la marca Lo que dice Eva.

Empecemos por definir las ventajas diferenciales que van a destacar los productos de la marca. Tomaremos aquellos que contaron con mayor relevancia en las respuestas de los dos tipos de mujeres encuestadas, Tipo Uno y Tipo Dos, estos fueron: Calidad con un 39\%, Confort 24\% y Buen Precio 21\% de una base de 100 encuestas coincidentales de mujeres latinas, ver tabla pag.43 capitulo III.

\subsubsection{Selección de ventajas competitivas correctas}

94“"Muchos mercadólogos piensan que las empresas deben, promover de forma agresiva sólo un beneficio ante el mercado meta. Pero otros piensan que las empresas deben posicionarse con base en más de un factor diferenciador. Esto podría ser necesario si dos o más empresas afirman ser la mejor en cuanto al mismo atributo". Más en un nicho de mercado tan competitivo como lo es el rubro de indumentaria (lencería femenina), donde muchas empresas comunican atributos físicos del producto como son: el diseño, la calidad, el precio o destacan el anhelo del ícono de belleza perfecto como beneficio de sus marcas/productos.

En consecuencia, se ha decidido sumar a los atributos anteriormente identificados como ventajas competitivas, la raíz de la marca especificada en la pag. 41 como otra ventaja, tal y como hizo ${ }^{95 “ B u r g e r ~ K i n g ~ q u e ~ p r o m u e v e ~ s u ~ e l e c c i o ́ n ~ p e r s o n a l: ~ " c o ́ m e l o ~ a ~ t u ~}$

\footnotetext{
${ }^{93}$ Kotler, P \& Armstrong, G.(2012). Estrategia de Marketing Impulsada por el Cliente: creación de valor para los clientes Meta. En Pearson Education (Eds.), Marketing (pp.207-215). Ciudad de México: Pearson Editorial.

${ }^{94}$ Kotler, P \& Armstrong, G.(2012). Estrategia de Marketing Impulsada por el Cliente: creación de valor para los clientes Meta. En Pearson Education (Eds.), Marketing (pp.207-215). Ciudad de México: Pearson Editorial.

${ }^{95}$ Kotler, P \& Armstrong, G.(2012). Estrategia de Marketing Impulsada por el Cliente: creación de valor para los clientes Meta. En Pearson Education (Eds.), Marketing (pp.207-215). Ciudad de México: Pearson Editorial.
} 
manera"', además de destacar otros atributos como: el sabor de las hamburguesas a las brasas, o el gran tamaño de las mismas. Tal determinación es tomada entendiendo que ${ }^{96}$ "la moda - sostiene Simmel - es una forma de vida peculiar, que pretende establecer un compromiso entre la tendencia a la nivelación social y la tendencia a la singularidad individual". Lo que genera un marco de inconformismo latente dentro de las clientas, que se enfrentan a un ícono de belleza inalcanzable.

En síntesis, las ventajas de la estrategia serían: el reconocimiento de la mujer latina y su belleza, seguido por la calidad, el confort y el buen precio de los productos pensados para ellas.

\subsubsection{Selección de la estrategia general de posicionamiento}

Después de haber analizado y relevado los atributos que se comunicarán por medio de la estrategia a desarrollarse, debemos elegir el formato que tendrá. Dicha estructura se retroalimentará de las ventajas competitivas seleccionadas anteriormente, con el fin de lograr posicionar la marca en el mercado meta.

Las acciones de posicionamiento de una marca ${ }^{97}$ "se denominan propuesta de valor, es decir, la mezcla completa de beneficios con los cuales la marca se diferencia y posiciona. Es la respuesta a la pregunta: ¿Por qué debo comprar su marca?". Lo que generó una segunda incógnita, ¿Cuál es la estrategia adecuada para la marca de lencería?, del presente trabajo. En consecuencia se tomó como base de análisis el siguiente cuadro propuesto por Kotler y Armstrong, en la pag. 213 de su libro Marketing como posibles propuestas de valor, estas son implementadas por empresas de diversos rubros, y de esta forma poder armar una estrategia acertada para la marca. Las propuestas de color verde son ganadoras, las de color colorado perdedoras y la amarrilla una propuesta marginal:

\footnotetext{
${ }^{96}$ Zygmunt, B. (2011), La moda, o el movimiento perpetuo. En Espasa Libros (Eds.), 44 Cartas desde el Mundo Líquido (pp.73-77). Barcelona: Editorial Espasa libros S.L.U.

${ }^{97}$ Kotler, P \& Armstrong, G.(2012). Estrategia de Marketing Impulsada por el Cliente: creación de valor para los clientes Meta. En Pearson Education (Eds.), Marketing (pp.207-215). Ciudad de México: Pearson Editorial.
} 


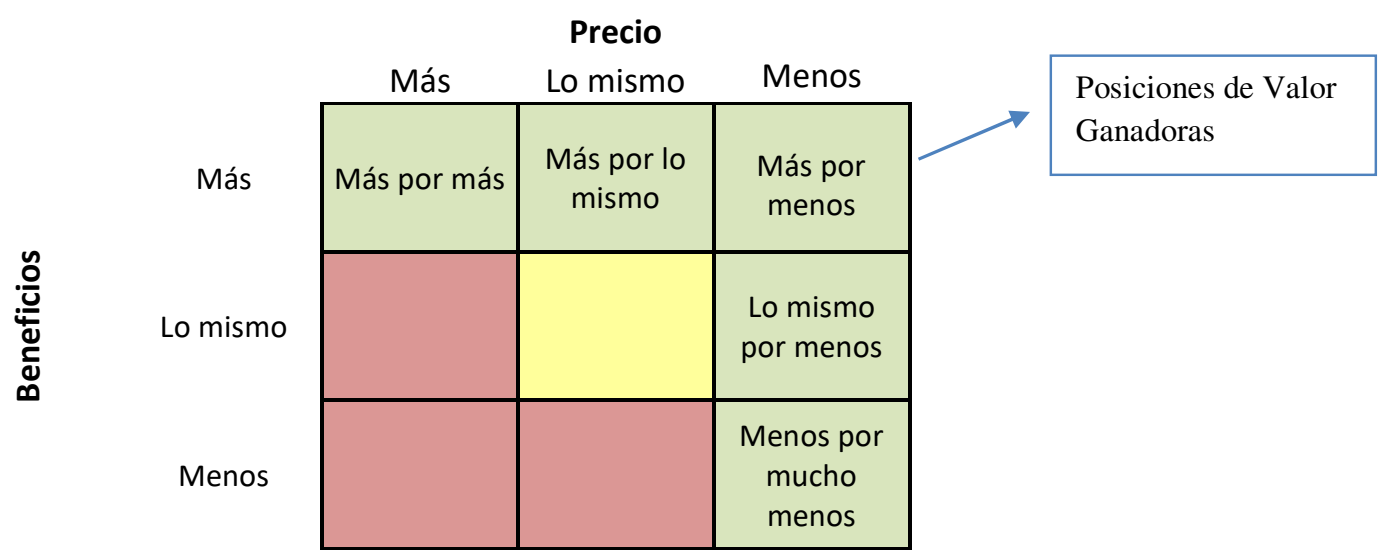

En esta instancia es oportuno refrescar nuevamente cual es el objetivo principal que persigue la marca a través de la estrategia a implementar: Convertirse en una marca con alto valor, exitosa y con altos volúmenes de ventas. Para ello lo principal es generar 98“una marca con valor positivo que deriva de la conexión y de los sentimientos que tienen los clientes respecto a una marca".

Ahora bien, teniendo en el radar el objetivo principal y los diferentes formatos, podemos decir que la estrategia a desarrollarse por la marca Lo que dice Eva en una etapa inicial, por lo menos, o de iniciación mientras se hace conocida en el mercado es el cuadrante de Más por menos según el cuadro de la presente página. Finalmente resolveremos una tercera pregunta ¿En qué consiste la estrategia?: En ofrecer productos con excelente calidad, diseño/confort, a precios más bajos que los que ofrecen marcas internacionales o nacionales con posicionamiento positivo en la mente de la mujer latinoamericana.

En conclusión, la estrategia además de cimentarse y de construirse a partir del pensamiento de expertos del marketing como lo son: Philip Kotler y Gary Armstrong, también tomó en cuenta el pensamiento de la mujer latina relevado en el trabajo de campo (encuestas), que se presentó en el capítulo II del presente trabajo, para el caso tomamos la tabla presentada en la pag. 32 . En donde el $58 \%$ de las mujeres encuestadas coincide en que las prendas de mejor diseño y calidad son para personas adineradas, y que las prendas de lencería femenina de marcas internacionales como Victoria's Secret, Calvin Klein son las de mejor calidad y diseño.

\subsection{Política de precios de la marca}

\footnotetext{
${ }^{98}$ Kotler, P \& Armstrong, G.(2012). Estrategia de asignación de marca: creación de marcas fuertes. En Pearson Education (Eds.), Marketing (pp.243-251). Ciudad de México: Pearson Editorial.
} 
En cuanto a la definición de la estrategia de precios que va a utilizar la marca y sus productos, se van a conjugar tres metodologías o formas de fijación de precios. El fin es construir una política única de fijación de precios, que contenga rasgos de estas tres metodologías a mencionar en breve, con las que se identifique la marca, en cuanto a sus valores y a lo que la marca desea transmitir a sus clientas.

La primera de ellas que actuaría como marco regulatorio de las siguientes se denomina fijación de precios psicológica,99 "ya que el precio dice algo del producto. Por ejemplo muchos consumidores utilizan el precio para juzgar la calidad," y "suelen pensar que los productos con precios altos tienen una mayor calidad", en consideración a uno de los atributos principales que desea transmitir la marca, como es la calidad, y la asociación mental con productos positivos, de buen nivel. De esta manera se puede establecer el principal parámetro regulatorio de la política de precio de la marca: los productos de la marca Lo que dice Eva deben tener el mayor precio posible.

El segundo rasgo que debe tener en cuenta la política de precio, es que es una marca nueva que carece de posicionamiento, y además que no es una marca que pretende ser selectiva en cuanto al nivel socioeconómico, (exclusiva para el nivel más alto de la pirámide). Tiene el desafío de posicionarse rápidamente como una marca de valor agregado para la mujer latina, que desea ganar participación en el share de mercado. Es por ello, que se apoya en la estrategia de fijación de precios para penetrar en el mercado, que es una práctica muy utilizada por

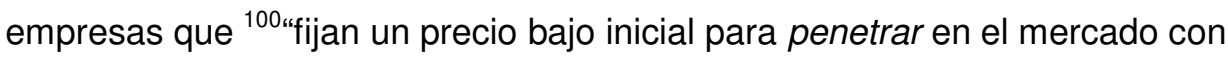
rapidez y profundidad, es decir, para atraer a una gran cantidad de compradores rápidamente y ganar una gran participación en el mercado".

En consecuencia, y tomando como base las anteriores prácticas de fijación de precios, se puede concluir que para terminar de formar la política de precio de la marca de lencería femenina naciente, se deben tener en cuenta los costos de producción y los gastos en los que asume la marca para producir un determinado producto, que varían por prenda, y por el tipo de mujer latina que los luzca; Tipos de mujer previamente definidos en Tipo uno y dos. Esta práctica de fijación de

\footnotetext{
${ }^{99}$ Kotler, P \& Armstrong, G.(2012). Estrategias de Fijación de Precios de Nuevos Productos. En Pearson Education (Eds.), Marketing (pp.314-323). Ciudad de México: Pearson Editorial.

${ }^{100}$ Kotler, P \& Armstrong, G.(2012). Estrategias de Fijación de Precios de Nuevos Productos. En Pearson Education (Eds.), Marketing (pp.314-323). Ciudad de México: Pearson Editorial.
} 


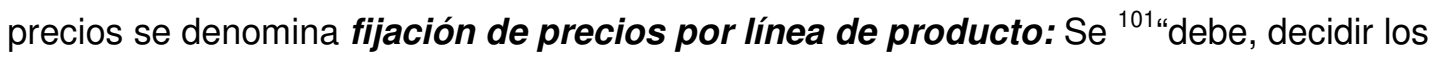
escalones de precios entre los diversos productos de la línea. Los escalones de precios deben tomar en cuenta las diferencias de costos entre los productos de la línea y, más importante, deben representar las diferencias en las percepciones que tienen los clientes del valor de las distintas características".

En conclusión la política de precios de la marca Lo que dice Eva se traduce en la siguiente ecuación

\begin{tabular}{|l|l|}
\hline $\begin{array}{l}\text { Política de } \\
\text { Precio de la }\end{array}$ & $\begin{array}{l}\text { Nivel de Precio que permita tener productos de buena calidad, con presentación } \\
\text { principales marcas del mercado, donde la percepción de la consumidora sea } \\
\text { Marca }\end{array}$ \\
$\begin{array}{l}\text { buena calidad a un precio cómodo, con el fin de maximizar la utilidad para la } \\
\text { marca. }\end{array}$ \\
\hline
\end{tabular}

\subsection{Estrategia y política comunicacional de la marca y sus productos}

En este punto del trabajo está claro que cualquier marca o compañía debe encontrar el camino, la forma de crear un vínculo emocional, de conectarse con la emoción de los consumidores, para tratar de despegarse de la competencia y de esa forma sobresalir sobre las demás marcas.

Lo anterior nos retrotrae a la hipótesis que dio origen al presente trabajo de investigación, la cual hará su contribución a la creación de la política de comunicación de la marca. Esta se refería a que ${ }^{102 ،}$ "las sociedades hipermodernas aparecen como sociedades de inflación decepcionante. Cuando se promete la felicidad a todos y se anuncian placeres en cada esquina, la vida cotidiana es una dura prueba." Anteriormente ${ }^{103 ، l a s ~ s o c i e d a d e s ~ t r a d i c i o n a l e s ~ t e n i ́ a n ~ e l ~ c o n s u e l o ~}$ religioso para mitigar la decepción; las sociedades hipermodernas utilizan de cortafuegos la incitación incesante a consumir, a gozar, a cambiar". Es aquí donde la marca Lo que dice Eva ve una oportunidad para conectarse de forma más genuina con la cliente adaptándose al tipo de sociedad actual, entendiendo que

104“la industria de la moda necesita exagerar las tendencias para alimentarse a sí

\footnotetext{
${ }^{101}$ Kotler, P \& Armstrong, G.(2012). Estrategias de Fijación de Precios de Nuevos Productos. En Pearson Education (Eds.), Marketing (pp.314-323). Ciudad de México: Pearson Editorial.

102 Lipovestsky, G.(2008). La Espiral de la Decepción. Productos. En Anagrama (Eds.), La sociedad de la decepción - entrevista con Bertrand Richard (pp.15-58). Barcelona: Anagrama Editorial.

${ }^{103}$ Lipovestsky, G.(2008). La Espiral de la Decepción. Productos. En Anagrama (Eds.), La sociedad de la decepción - entrevista con Bertrand Richard (15-58). Barcelona: Anagrama Editorial.

${ }^{104}$ Aubele, C. (2010). Víctimas de la Moda. En Aguilar (Eds.), Secretos del Vestidor (pp.27-28). Buenos Aires: Editorial Aguilar, Altea, Taurus, Alfaguara, S.A.
} 
misma, y los medios contribuyen a esa exageración porque deben producir novedad," pero que a su vez la comunicación de la marca debe estar alejada de

105“formatos, patrones que se imponen, circulan y se venden. Uno de ellos es la juventud; otro la delgadez. Y como nadie responde exactamente al patrón, la insatisfacción viene por añadidura."

Ahora bien abordaremos la estrategia en dos partes, la primera que denominamos formato de comunicación, está relacionada directamente con lo que en definitiva la marca va a trasmitir en sus comunicaciones para conectarse con su público meta, seguido a esto, se hablará de los medios o canales de comunicación a utilizarse para llegar a la interlocutora, a lo que se denomina mezcla de comunicación.

\subsubsection{Formato de comunicación}

Una vez que se decidió y se tiene en claro la estrategia que la marca va a comunicar, daremos paso a enriquecer la misma. Para ello ${ }^{106}$ "resulta conveniente que cada idea, finalmente seleccionada y enriquecida, se transcriba en una ficha. Ésta debe abarcar, como mínimo, los siguientes puntos: nombre, descripción, ventajas, desventajas, variantes, modos de realización, problemas y dificultades que deban resolverse para implementar la idea. Eduardo Kastika, en Desorganización creativa y organización innovadora (1994), resume las veinte recomendaciones de Geoffrey Rawlynson basadas en lo que se debe hacer o no; un must para todo brainstormer que se estime como tal.

Ahora bien, daremos inicio a la realización de dicha ficha para enmarcar el contexto en el cual se encuadrara la política de comunicación de la marca, para que los creativos después puedan darle forma a cualquier campaña comunicacional. La misma estará alineada por el espíritu que tiene la marca, el

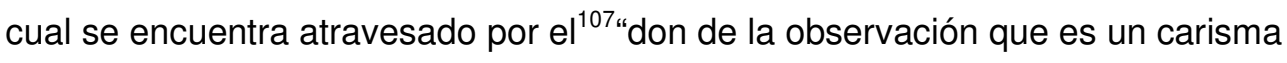
que ningún creativo tiene en menos. En términos publicitarios, el secreto del buen publicitario es observar el interior de la naturaleza humana (Bill Bernbach)".

\footnotetext{
${ }^{105}$ Aubele, C. (2010). La Industria de la Insatisfacción. En Aguilar (Eds.), Secretos del Vestidor (pp.29-30). Buenos Aires: Editorial Aguilar, Altea, Taurus, Alfaguara, S.A.

${ }^{106}$ Aprile, O, C. (2000). El Brainstorming y Otras Cuestiones: las Técnicas Creativas. En Paidós (Eds.), La publicidad Estratégica (pp.155-190). Buenos Aires: Editorial Paidós, SAICF.

${ }_{107}$ Aubele, C. (2010). La Industria de la Insatisfacción. En Aguilar (Eds.), Secretos del Vestidor (pp.29-30). Buenos Aires: Editorial Aguilar, Altea, Taurus, Alfaguara, S.A.
} 
A continuación se presentará la ficha de la política comunicacional de la marca, la cual tendrá como objetivo general lograr conectar al público meta con la marca desde la emoción:

\begin{tabular}{|c|c|}
\hline Raíces de la Marca & $\begin{array}{l}\text { Marca que invita a romper con el pensamiento de belleza única y perfecta. } \\
\text { Marca que invita a la mujer latina a reconocerse bella e interesante. } \\
\text { Productos de alta calidad, diseño, confort a precios accesibles para las clientas. }\end{array}$ \\
\hline $\begin{array}{l}\text { Entorno } \\
\text { Competitivo }\end{array}$ & $\begin{array}{l}\text { Cada vez más las mujeres muestran su inconformismo por los modelos de belleza } \\
\text { impuestos por grandes marcas, como Victoria's Secret: }{ }^{108} \text { "Las ventas en la mítica } \\
\text { compañía de lencería, Victoria's Secret han decaído como nunca antes. } \\
\text { Comprender el por qué es sencillo. Y es que la marca ha creado a partir de sus } \\
\text { prendas un imaginario de la mujer que no es real”. } \\
\text { Compite con marcas que tienen presencia en el mercado tradicional con locales } \\
\text { propios, hipermercados, etc y además online: Victoria's Secret, leonisa, Caro } \\
\text { cuore, Cocot, Selú, Calvin Klein... }\end{array}$ \\
\hline Target & Mujeres de 25 a 50 años, con un NSE ABC1 - C2 - C3 \\
\hline Insigth & $\begin{array}{l}\text { - Eres bella, eres mágica, eres única, por eso necesitas una marca como } \\
\text { vos. } \\
\text { - La marca sin vos no existe, Vos eres la marca. } \\
\text { - Las mujeres como vos, merecen de una marca que te muestre sexy. } \\
\text { - Las mujeres como vos merecen de prendas con diseño, buena calidad y } \\
\text { buenos precios. }\end{array}$ \\
\hline Beneficios & $\begin{array}{l}\text { Marca que reconoce la belleza de la mujer, que valora a la mujer real, que premia } \\
\text { a la mujer genuina con prendas de calidad, diseño y buenos precios. }\end{array}$ \\
\hline $\begin{array}{l}\text { Responsabilidad } \\
\text { Valores y Creencias }\end{array}$ & $\begin{array}{l}\text { - } \quad \text { Belleza, Sensualidad, empoderamiento, realismo, satisfacción } \\
\text { - } \quad \text { Humildad, respeto, sensibilidad, comodidad, verdad } \\
\text { - Enmarcado con el ícono EVA que representa las necesidades de las } \\
\text { consumidoras, se identifica con ellas, y se ve como ellas. }\end{array}$ \\
\hline Razones para Creer & Marca hecha para mujeres reales, como vos \\
\hline Discriminador & $\begin{array}{l}\text { Marca que resalta el reconocimiento de la belleza propia y genuina, mujeres bellas } \\
\text { que merecen productos de calidad, diseño con buen precio }\end{array}$ \\
\hline Esencia & La belleza depende de vos \\
\hline
\end{tabular}

\subsubsection{Mezcla de comunicación de marketing}

Ahora hablaremos de lo que usualmente se conoce como mezcla de comunicación de marketing, ¿Qué significado tiene dicho termino?: 109“consiste en la

\footnotetext{
${ }^{108}$ Revista Vix. Victoria's Secret No Queremos Tu Lencería. Recuperado el 19 de marzo del 2019 de: https://www.vix.com/es/vida-e-inspiracion/214199/victorias-secret-no-queremos-tu-lenceria-cada-vez-menosmujeres-se-sienten-representadas-por-la

${ }^{109}$ Kotler, P \& Armstrong, G. (2012). Comunicación de Valor para el Cliente. En Pearson Education (Eds.), Marketing (pp.406-417). Ciudad de México: Pearson Editorial.
} 
mezcla específica de publicidad, relaciones públicas, ventas personales, promoción de ventas y herramientas de marketing directo que utiliza la compañía para comunicar valor para el cliente de forma persuasiva y establecer relaciones con éste", ahora de forma breve definiremos cada uno de estos elementos para poder armar los canales que debería utilizar regularmente la marca del presente estudio:

- 110،Publicidad: Cualquier forma pagada de presentación y promoción, incluye televisión, anuncios impresos, internet, material en exteriores.

- Promoción de Ventas: Incentivos a corto plazo que fomentan la compra o venta de productos, incluye descuentos, cupones, exhibidores y demostraciones.

- Ventas Personales: Presentación personal de la fuerza de ventas.

- Relaciones públicas: Generación de buenas relaciones con los clientes, a través de publicidad favorable, incluye boletines de prensa, patrocinios, eventos, páginas web.

- Marketing Directo: Conexiones directas con consumidoras individuales seleccionadas boletines, catálogos, marketing telefónico, internet, marketing móvil, páginas web".

Antes, hablemos de ¿Cómo se comportan las comunicaciones en la coyuntura actual?, y que hacen los actuales publicistas para armar comunicaciones eficientes. Desde hace un par de años las comunicaciones han venido sufriendo ciertas transformaciones que han obligado a las marcas, empresas a repensar sus estrategias de comunicación. Además de igual forma a revaluar ¿Cuáles? canales deben utilizar, y ¿Cómo? difundir sus mensajes y

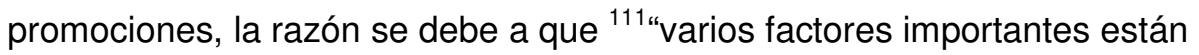
cambiando el rostro de las comunicaciones de marketing actuales. En primer lugar, los consumidores están cambiando; en esta época digital e inalámbrica están mejor informados y más capacitados para las comunicaciones. En lugar de conformarse con la información proporcionada por el mercadólogo, pueden utilizar internet y otras tecnologías para encontrarla por su cuenta. Tienen mayores posibilidades de conectarse con otros consumidores para intercambiar

\footnotetext{
${ }^{110}$ Kotler, P \& Armstrong, G. (2012). Comunicación de Valor para el Cliente. En Pearson Education (Eds.), Marketing (pp.406-417). Ciudad de México: Pearson Editorial.

${ }^{111}$ Kotler, P \& Armstrong, G. (2012). Comunicación de Valor para el Cliente. En Pearson Education (Eds.), Marketing (pp.406-417). Ciudad de México: Pearson Editorial.
} 
información relacionada con las marcas, o incluso crear sus propios mensajes de marketing".

Ahora bien, ${ }^{112 ، " l o s ~ p u b l i c i s t a s ~ e s t a ́ n ~ a n ̃ a d i e n d o ~ u n a ~ a m p l i a ~ s e l e c c i o ́ n ~ d e ~ m e d i o s ~}$ medios más especializados y altamente dirigidos para alcanzar segmentos de clientes más pequeños con mensajes interactivos más personalizados", dichos medios son: redes sociales, Internet, correos electrónicos, Youtube y la televisión por cable, ya que ${ }^{113 “ l a ~}$ televisión en general, las revistas, los periódicos y otros medios de comunicación masiva continúan siendo muy importantes, pero su dominio está decayendo" frente a los medios mencionados anteriormente.

Ahora procedamos finalmente a realizar la diagramación de los canales que la marca Lo que dice Eva debe utilizar regularmente, por lo menos desde su inicio, teniendo en cuenta el panorama de lo que sucede en el mundo de las comunicaciones de las marcas actuales con los clientes y las herramientas de la mezcla de comunicaciones, también conocida como herramientas promocionales, tomando como referencia el cuadro de la pag.413 del libro Marketing de los autores Kotler y Armstrong:

\section{HERRAMIENTAS PROMOCIONALES/COMUNICACIONALES LO QUE DICE EVA}

Publicidad: Fuerte campaña online Internet/Adwords - redes sociales (Instagram/Facebook), Youtube y anuncios impresos a entregar en la vía pública - canal off.
Marketing Directo: Campañas de email marketing, promociones del e-shops, contacto de revendedoras.

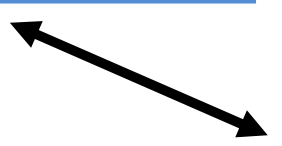

Promoción de Ventas: Promociones, cupones, descuentos y sorteos en el canal online y off
Ventas Personales: Incluye coaching del mensaje de la marca en exhibiciones y demostraciones
Marca: Las mujere como vos, merecen de una marca como "Lo que dice Eva", que sabe que sos..., Sexy, bella, real y verdadera.

\footnotetext{
112 Kotler, P \& Armstrong, G. (2012). Comunicación de Valor para el Cliente. En Pearson Education (Eds.), Marketing (pp.406-417). Ciudad de México: Pearson Editorial.

${ }^{113}$ Kotler, P \& Armstrong, G. (2012). Comunicación de Valor para el Cliente. En Pearson Education (Eds.), Marketing (pp.406-417). Ciudad de México: Pearson Editorial.
}

Relaciones Publicas: Catálogo de productos impreso, landing para el canal Online, eventos con influencers, e-shops.

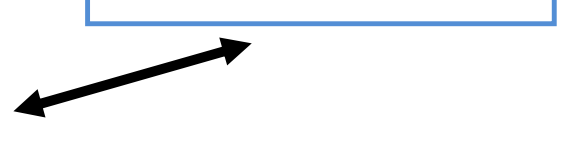




\subsection{Diagramación de la estrategia de canales y comercialización}

Las diversas marcas se enfrentan a un desafío constante a diario, en lo refiere a la elección del canal o de los canales adecuados que debe elegir para hacer llegar sus productos al cliente final, para el caso abordado en este trabajo de tesis, hablamos de una futura marca/compañía que intenta comercializar productos de consumo masivo, o sea que el tipo de negocio en el cual incursionaría sería B\&C - Business \& Consumer. En este punto nos encontramos con los intereses propios que debe manejar la marca: maximización del costobeneficio, de los costos de distribución, comisiones de posibles intermediarios frente a la eficiencia que deben manejar los mismos, refiriéndose a la entrega de los artículos de lencería y los tiempos de entrega, con el fin de generar clientas satisfechas. Teniendo dicha máxima en el radar además nos encontramos que

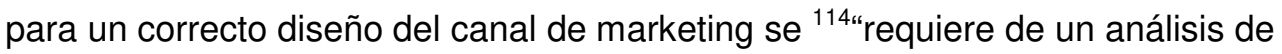
las necesidades de los consumidores, el establecimiento de objetivos, la identificación de las principales alternativas de éste y su evaluación."

\subsubsection{Política de distribución}

La marca a crearse tiene en claro que los posibles canales de marketing a utilizar ${ }^{115 " f o r m a n ~ p a r t e ~ d e ~ l a ~ r e d ~ g e n e r a l ~ d e ~ t r a n s f e r e n c i a ~ d e ~ v a l o r ~ a l ~ c l i e n t e . ~ C a d a ~}$ miembro y nivel del canal añade valor para los clientes. Así el diseño del canal de marketing se inicia al descubrir lo que los consumidores meta desean del canal," en ésta instancia estaría haciendo falta esclarecer y puntualizar las necesidades de las clientas a las que se pretende fidelizar para que ejerzan una y otra vez la acción de comprar los diferentes productos de la marca.

En este punto es donde se debe tener claridad de lo que pretenden las mujeres latinas de las diferentes marcas de lencería, se ha decidido tomar como soporte el trabajo de campo realizado a través de encuestas coincidentales, presentado en el capítulo II del presente trabajo. Se tomaron como base dos preguntas referidas a los canales: La primera relacionada al lugar donde ejerce la acción de compra y la segunda a los medios o lugares físicos donde se asesora regularmente antes de concretar la compra, a continuación se presentarán los

\footnotetext{
${ }^{114}$ Kotler, P \& Armstrong, G. (2012). Decisiones del Diseño de Canal. En Pearson Education (Eds.), Marketing (pp.351-353). Ciudad de México: Pearson Editorial.

${ }^{115}$ Kotler, P \& Armstrong, G. (2012). Decisiones del Diseño de Canal. En Pearson Education (Eds.), Marketing (pp.351-353). Ciudad de México: Pearson Editorial.
} 
resultados arrojados tomando totales unificados, agrupando los dos tipos de mujer que contempla la marca como mercado meta, siendo información conveniente para la marca en cuanto al armado de la política de distribución a implementar:

\begin{tabular}{|c|c|c|}
\hline Pregunta Encuesta & Canal elegido & Resultado \\
\hline \multirow{2}{*}{$\begin{array}{c}\text { ¿Usualmente cuando compra lencería donde } \\
\text { lo hace?, mencione dos lugares siendo 1 la } \\
\text { mayor frecuencia y 2 el de menor frecuencia. }\end{array}$} & Shoppings/locales a la calle & $51 \%$ \\
\cline { 2 - 3 } & Por folleto o catalogo & $18 \%$ \\
\hline $\begin{array}{c}\text { Mencione cuales son los medios/ lugares que } \\
\text { usted consulta regularmente para enterarse } \\
\text { del mundo de lencería y sus marcas, enumere } \\
\text { de 1 a 3 siendo 1 la más relevante y 3 la menos } \\
\text { relevante }\end{array}$ & Shopping/locales de ropa/lencería & $3 \%$ \\
\cline { 2 - 3 } & Marca referida por amiga/familiar o \\
persona conocida & $23 \%$ \\
\hline
\end{tabular}

Fuente elaboración propia: Relevamiento encuestas coincidentales, base 100 casos

Ahora bien, después de haber analizado la información y teniendo en cuenta que el objetivo de la marca es la maximización de la relación costo-beneficio, establecemos los parámetros de la estrategia de comercialización de canales:

- Implementación, creación y generación de un canal de venta directa a través de revendedoras por folleto o catálogo de productos - asesoría

- Venta Directa a través de e-shops propios de la marca teniendo en cuenta la demanda sostenida que presenta el canal día a día.

- Venta mayorista a casas de lencería femenina con presencia en locales a la calle o shopping

\subsubsection{Diseño del formato de venta y distribución}

Entendiendo la estrategia de distribución y contemplando el objetivo que implementaría la marca, teniendo en cuenta las necesidades de las clientas latinoamericanas encuestadas previamente. La política que se ha decidido para la marca con el fin de vender sus productos y de llegar a las clientas es el sistema de distribución 


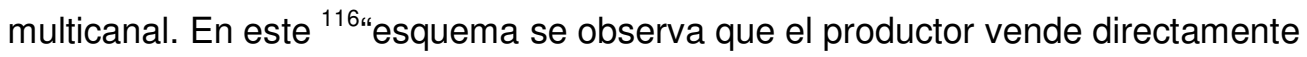
al segmento 1 consumidores a través de catálogos, telemarketing e Internet, y alcanza al segmento 2 de consumidores por medio de minoristas. El productor vende de manera indirecta al segmento 1 de negocios, por medio de distribuidores y concesionarios, y al segmento 2 de negocios a través de su propia fuerza de ventas."

En esta estructura estaríamos cumpliendo con el objetivo de la estrategia de canales en cuanto a la reducción de costos, ya que la distribución de los productos de la venta a realizarse a través de folletos e internet la asumirían las clientas, pagando a empresas de courier para que le hagan llegar las compras realizadas. Ahora bien, los costos de distribución se achicarían notablemente gracias a esta estructura, ya que la venta por internet no genera comisiones, quedando la venta mayorista a minoristas, en donde las comisiones y premios de las revendedoras y la fuerza de ventas si las asumiría la marca, pero para el caso de mayoristas los costos de distribución se reducirían por vender grandes volúmenes de mercadería.

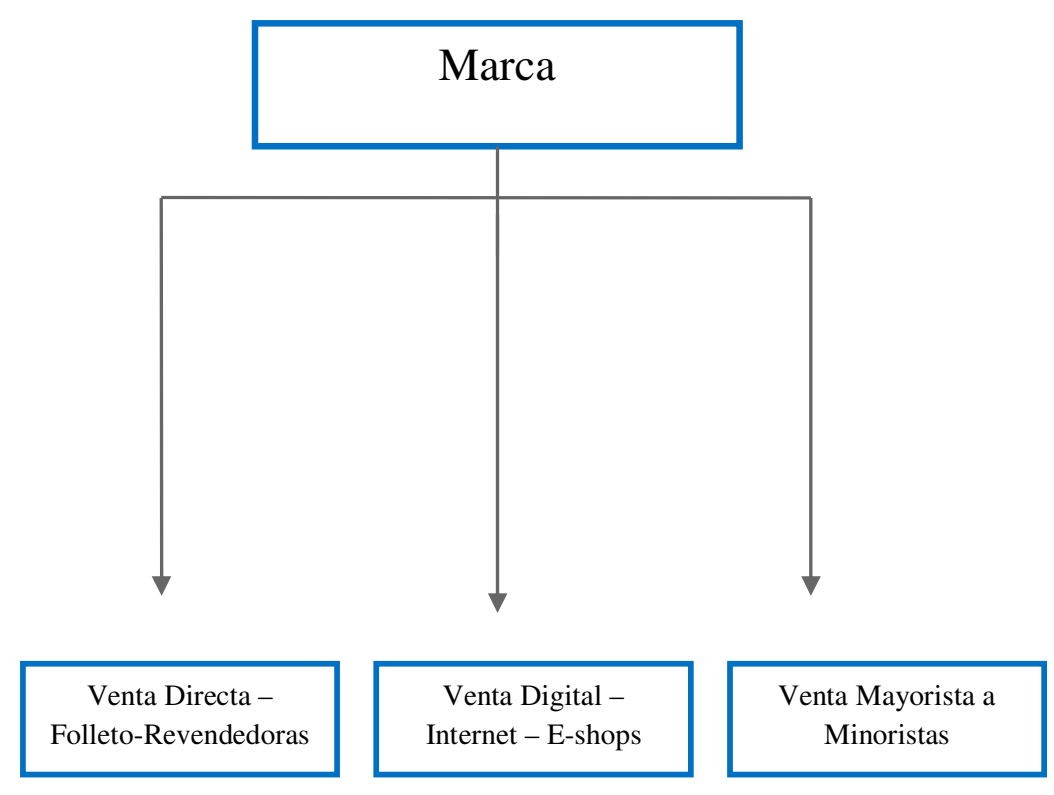
${ }_{116}$ Kotler, P \& Armstrong, G. (2012). Sistema de Distribución Multicanal. En Pearson Education (Eds.),
Marketing (pp.349-350). Ciudad de México: Pearson Editorial. 


\section{CONCLUSIONES}

La mujer latina actual no termina de estar satisfecha con los productos y el mercado de lencería actual, o sea sus necesidades no están completamente cubiertas ni descubiertas.

La mayoría de las mujeres dicen no sentirse excluidas por las marcas de lencería femeninas actuales, pero están de acuerdo, con que las marcas de lencería proponen un tipo de mujer perfecta (piernas alargadas, estilizada, joven) que hace sentir frustración a la mayoría de las mujeres.

117“La idea de raza es, literariamente, un invento. No tiene nada que ver con la estructura biológica de la especia humana. En cuanto a los rasgos fenotípicos, éstos se hallan obviamente en el código genético de los individuos y grupos, y en ese sentido específico son biológicos."

Las mujeres sienten a diario la ${ }^{118 " p r e s i o ́ n ~ d e ~ l o s ~ a n u n c i o s ~ s i n o ~ t a m b i e ́ n, ~ y ~}$ probablemente más que ninguna otra cosa, la presión, tal vez menos persistente, pero mucho más efectiva, del entorno social, de los estándares ${ }^{119 "}$ de belleza.

120،“'Las compañías que tienen un marketing exitoso hacen casi cualquier cosa por mantener satisfechos a sus clientes importantes". "Las empresas inteligentes buscan deleitar a los clientes prometiendo tan sólo lo que son capaces de dar, y luego entregando más de lo que prometieron"'”.

La marca es el principal activo que tiene una empresa como lo definió un antiguo director de McDonald's que declaro ${ }^{121}$ "si cada bien que poseemos, cada edificio y cada pieza de equipo se destruyeran en un terrible desastre natural, seríamos capaces de pedir prestado todo el dinero para reemplazarlo con rapidez debido al valor de nuestra marca...La marca es más valiosa que la totalidad de estos activos".

${ }^{117}$ Quijano, A.(2000). Colonialidad del Poder, Eurocentrismo y América Latina. En La Colonialidad del Saber: Eurocentrismo y Ciencias Sociales. Perspectivas Latinoamericanas. Recuperado de http://bibliotecavirtual.clacso.org.ar/ar/libros/lander/quijano.rtf

${ }^{118}$ Zygmunt, B. (2011), El consumo Adolescente. En Espasa Libros (Eds.), 44 Cartas desde el Mundo Líquido (pp.51-55). Barcelona: Editorial Espasa libros S.L.U.

${ }^{119}$ Revista Belleza y Salud. La complexión Latina. Recuperado de: http://www.fucsia.co/belleza-ysalud/articulo/la-complexion-latina/4042

${ }^{120}$ Kotler, P \& Armstrong, G.(2012). Establecimiento de las relaciones con el cliente. En Pearson Education (Eds.), Marketing (12-13). Ciudad de México: Pearson Editorial.

${ }^{121}$ Kotler, P \& Armstrong, G. (2012). Productos, Servicios y Marcas. En Pearson Education (Eds.), Marketing (pp.222-255). Ciudad de México: Pearson Editorial. 
Por consiguiente, los insigth son intangibles enormes para cualquier negocio, los de Lo que dice Eva son:

- Marca que invita a romper con el pensamiento de belleza única y perfecta.

- Marca que invita a la mujer latina a reconocerse bella e interesante.

122“Una compañía no puede desarrollar una imagen consistente en la público de la noche a la mañana, utilizando sólo algunos anuncios. Si Ritz-Carlton significa calidad, esta imagen debe estar sustentada por todo lo que la empresa hace".

A partir del estudio anterior entendimos, que Lo que dice Eva no debe ser identificada de forma masiva solo con los atributos físicos de los productos de la marca: Calidad, confort, diseño y precio. Lo importante es generar una conexión emocional con el cliente. Marca para la mujer Latina, que reconoce su belleza, sus necesidades y está hecha para ella.

Lo que entiende la marca es que el ${ }^{123 ، " e m p a q u e ~ p o d r i ́ a ~ s e r ~ l a ~ u ́ l t i m a ~}$ oportunidad de los comerciantes de influir en los compradores".

124“La industria de la moda necesita exagerar las tendencias para alimentarse a sí misma, y los medios contribuyen a esa exageración porque deben producir novedad."

125“Los consumidores están cambiando; en esta época digital e inalámbrica están mejor informados y más capacitados para las comunicaciones. En lugar de conformarse con la información proporcionada por el mercadólogo, pueden utilizar internet y otras tecnologías para encontrarla por su cuenta. Tienen mayores posibilidades de conectarse con otros consumidores para intercambiar información relacionada con las marcas, o incluso crear sus propios mensajes de marketing."

\footnotetext{
${ }^{122}$ Kotler, P \& Armstrong, G. (2012). Selección de una Estrategia de Diferenciación y Posicionamiento. En Pearson Education (Eds.), Marketing (pp.208-215). Ciudad de México: Pearson Editorial.

${ }^{123}$ Kotler, P \& Armstrong, G.(2012). Diseño de una estrategia y una mezcla de marketing impulsada por los consumidores. En Pearson Education (Eds.), Marketing (pp.232). Ciudad de México: Pearson Editorial.

${ }^{124}$ Aubele, C. (2010). Víctimas de la Moda. En Aguilar (Eds.), Secretos del Vestidor (pp.27-28). Buenos Aires: Editorial Aguilar, Altea, Taurus, Alfaguara, S.A.

${ }^{125}$ Kotler, P \& Armstrong, G. (2012). Comunicación de Valor para el Cliente. En Pearson Education (Eds.), Marketing (pp.406-417). Ciudad de México: Pearson Editorial.
} 
Gracias al trabajo de campo realizado se puede concluir que las prendas que más les incentiva a comprar a la mujer latina: es la lencería de uso diario, que le resulte cómoda primordialmente.

El principal medio de consulta para las latinas son los comercios físicos (retail) con un 34\%, seguido por un $23 \%$ el mundo digital (internet), y finalmente por el boca en boca (referido), datos relevados en el trabajo de campo.

La marca Lo que dice Eva en cuanto a la relación precio- Marca se debe posicionar en un precio intermedio entre las marcas internacionales y las nacionales, mostrándose como un atributo que refuerza su conexión emocional. 


\section{Anexo - encuesta de campo}

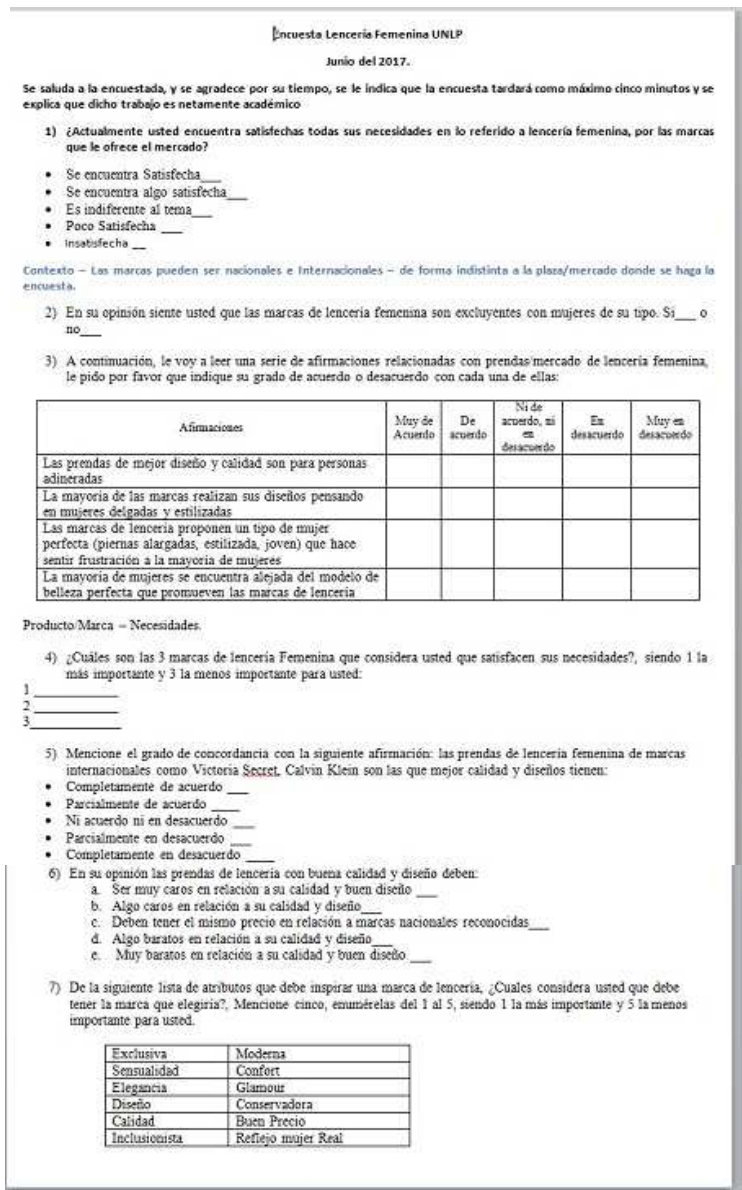

¿Cual es el maximo nivel de estudios que alcanzo la persona que más aporta?

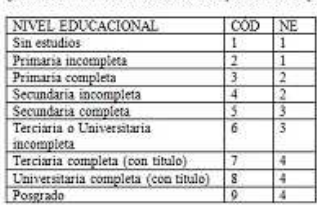

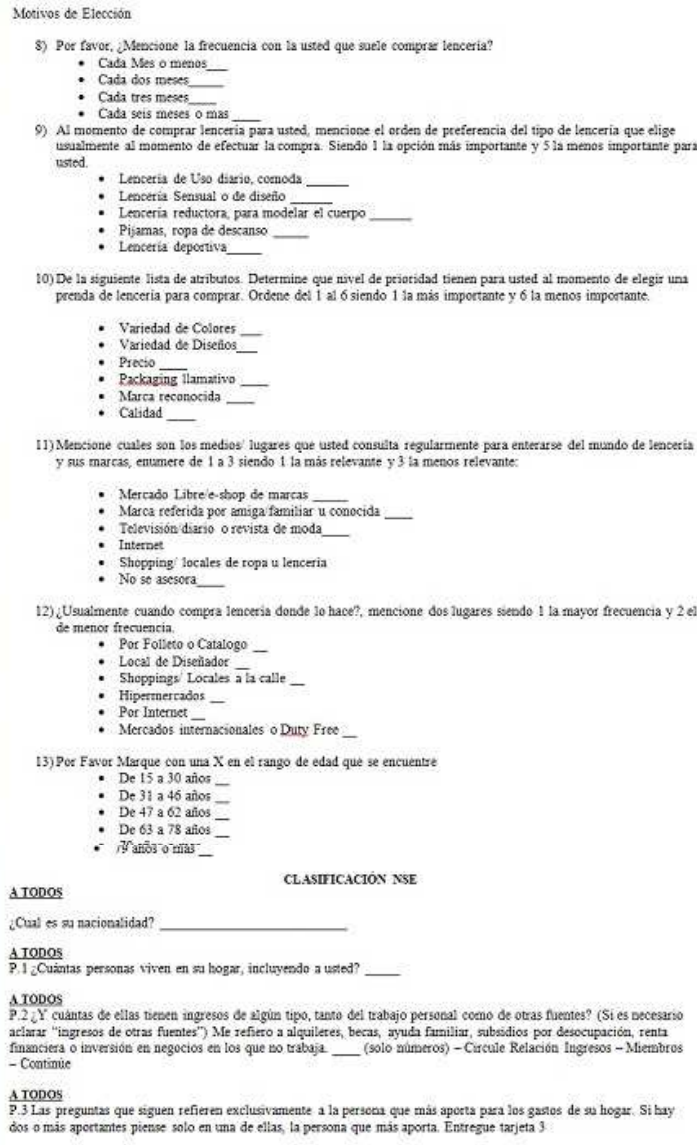

12) ¿Usuaimente cuando compra lenceria donde lo hace?, mencione dos lugares siendo 1 ta mayor frecuencia y $2 \mathrm{el}$ - Por Folitero o Catalogo

Cual es as nacionalidad?

A TODOS

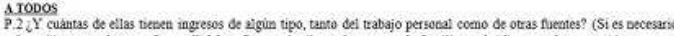

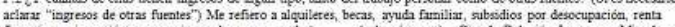

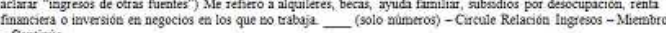
- Continic

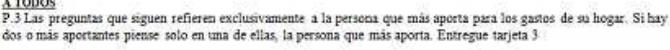

A TODOS-EXCLTSTADOR: DETERMINE SIES OCLPADO,DESOCLPADQ, TRILADQPENSTONADOC OTRO
NACTINO

P4. Actualmente esa persone esai trabzindo?

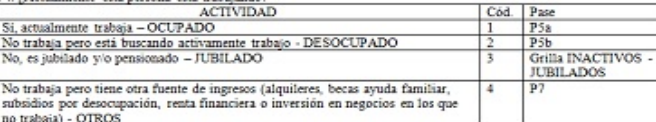

AOCIPADOS-TARJIASS

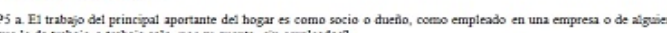

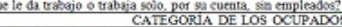

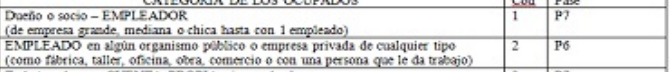
ADESOCLPADOS-TABNETAsB

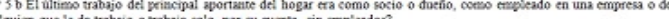

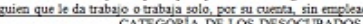

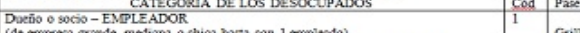

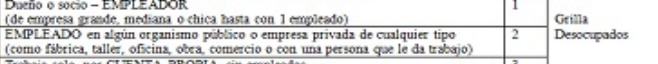

AEMPLEADOSCON OSI PERSONALA CARCO

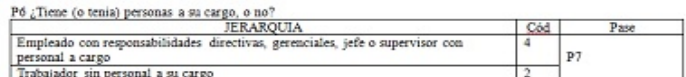

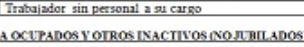

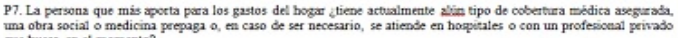
que buxza en es mesemento?

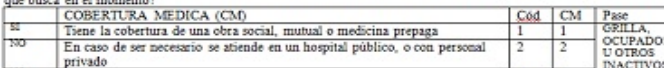

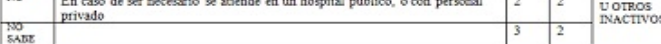


7. Bibliografía

\section{Libros impresos y digitales}

- Aubele, C. (2010). Secretos del Vestidor (4 $4^{\underline{a}}$ ed.). Buenos Aires: Editorial Aguilar, Altea, Taurus, Alfaguara, S.A.

- Aprile, O, C. (2000). Publicidad Estratégica (1 $\stackrel{a}{a}$ ed.). Buenos Aires: En Paidós SAICF.

- Kotler, P., Armstrong, G. (2012). Marketing (14 ed.). México: Pearson educación de México S.A.

- Lipovestsky, G. (2008). La sociedad de la decepción - Entrevista con Bertrand Richard ( $1^{a}$ ed.). Barcelona: Anagrama S.A.

- Posner, H. (2011). Marketing de moda (2da ed.). Barcelona: Gustavo Gili S.A.

- Quijano, A. (2000). En La Colonialidad del Saber: Eurocentrismo y Ciencias Sociales. Perspectivas Latinoamericanas. Recuperado el 10 de octubre del 2018 de http://bibliotecavirtual.clacso.org.ar/ar/libros/lander/quijano.rtf

- Riviére, M. (2014). Diccionario de la Moda Los Estilos del Siglo XX. Editorial: Google Pay Libros.

- Vázquez Casco, A.I., Martínez Caballero, E. (2006). Marketing de la moda (2da ed.). Madrid: Pirámide.

- Vigarello, G. (2009). Historia de la belleza - El cuerpo y el arte de embellecer desde el Renacimiento hasta nuestros días (1 ${ }^{\underline{a}}$ ed.). Buenos Aires: Nueva visión.

- Zygmunt, B. (2011). 44 Cartas desde el mundo líquido (1 ${ }^{a}$ ed.). Barcelona: Espasa libros S.L.U.

\section{Publicaciones y revistas de internet}


- Revista Belleza y Salud. La complexión Latina. Recuperado el 10de febrero del 2019 de: http://www.fucsia.co/belleza-y-salud/articulo/lacomplexion-latina/4042

- Carreño,L.(2018). "Cómo definir Misión, Visión y Valores en tu Marca". Recuperado el 10 de agosto del 2018. Recuperado de: https://smilemkt.com.ar/definir-mision-vision-valores/

- Clarín. (2017. Calvin Klein eligió a una modelo de 73 años para su campaña de ropa interior. Recuperado el 11 de febrero del 2018 de https://entremujeres.clarin.com/entremujeres/moda/lo-mas-trendy/calvinklein-eligio-modelo-73-anos-campana-ropa-interior 0 BkH-TM60l.html.htm

- Leonisa. Compañía. (2017). Recuperado el 09 de febrero del 2018 de. http://www.leonisa.com/sp/.htm

- OMS Datos Mundial. (2017). Tallas medias de hombres y mujeres. Recuperado el 02 de mayo del 2019 de https://www.datosmundial.com/estatura-promedio.php

- Rey,C.(2014). La Misión de la Marca. Voces para entendernos. Barcelona, España: Sumando Historias. Recuperado 9 de julio del 2018 de:

http://www.sumandohistorias.com/voces/para-entendernos/la-mision-de-la$\underline{\text { marcal }}$

- Touché. (2017). Compañía. Recuperado el 10 de marzo del 2018 de http://touche.com.co/compania/.htm

- Revista Vix. Victoria's Secret No Queremos Tu Lencería. Recuperado el 19 de marzo del 2019 de: https:/www.vix.com/es/vida-einspiracion/214199/victorias-secret-no-queremos-tu-lenceria-cada-vezmenos-mujeres-se-sienten-representadas-por-la

- Victoria's, S. Mercado Victoria's Secret. Recuperado el 07 de febrero del 2018 de http://victoriassecr.blogspot.com.ar/.html

- Vogue España. (s.f). Calvin Klein Diseñador. Recuperado el 09 de febrero del 2018 de http://www.vogue.es/moda/modapedia/disenadores/calvinklein/266.htm

\section{Material académico}

- Castro Telgado, C. (2011). Diseño de colección según los estereotipos corporales y la demanda de la sociedad argentina (Proyecto de Grado, Universidad de Palermo, Buenos Aires). Recuperada el 07 de febrero del 2018 de http://fido.palermo.edu/servicios dyc/proyectograduacion/archivos/431.pdf 
- Castro, T.C. (2011). Lencería a Medida (tesis de grado). Recuperado el 23 de julio de

http://fido.palermo.edu/servicios dyc/proyectograduacion/archivos/431.pdf. $\underline{\mathrm{htm}}$ 
"Declaro bajo juramento que esta tesis fue elaborada por mí, que no utilicé ningún otro material que no haya dado a conocer en las referencias y que no utilicé frases o párrafos de otros autores y que este trabajo de tesis nunca ha sido presentado ante un comité de evaluación de tesis y que no transgrede derechos de terceros."

Julián Andrés Mendoza O’Byrne

D.N.I 94.248 .456 